\title{
Grupo Sul e a Revolução Modernista em Santa Catarina
}

\author{
Rogério F. Guerral \\ Arno Blass ${ }^{2}$
}

Universidade Federal de Santa Catarina

\section{Um mundo em transformação}

$\mathrm{O}$

modernismo surgiu em São Paulo, a cidade que mais progredia no país. $O$ início do século 20 foi marcado por inovações, como o surgimento de veículos automotores, a eletrificação das vias públicas, as vacinas e os antibióticos, o transporte de massa (trens e bondes); no ambiente doméstico, as famílias contavam com as radiolas e machinas de cozer. O cenário urbano se encontrava em rápida transformação, como o calçamento das ruas e a construção de fura-céos (os arranha-céus e, mais tarde, edificios). A indústria alimentícia estava dando seus primeiros passos e muitos não tinham dúvidas de que o futuro seria mais seguro e confortável.

As primeiras décadas do século 20 também foram carregadas de sobressaltos, como a deflagração da I Guerra Mundial (1914-18) e a Revolução Russa (1917-22), episódios que culminaram em profundas mudanças na sociedade. Os aeroplanos foram criados por Santos Dumont e irmãos Wright; eles causaram tanto admiração quando temor nas mentes esclarecidas, pois permitiam o encurtamento das distâncias, mas logo se demonstraram úteis na facilitação do bombardeio de tropas inimigas e deslocamentos rápidos de contingentes militares.

O mundo das artes foi contaminado por esse mundo em transformação. As descobertas científicas e os novos artefatos tecnológicos proporcionavam bem-estar, mas mudaram os costumes e influenciaram o relacionamento do homem com a natureza. Cientistas e os intelectuais se encantavam com as mudanças e punham-se a imaginar como seria o mundo no distante ano 2000, o novo milênio. Ferdinando Laboriau (1885-1928), uma dos engenheiros mais brilhantes de sua geração, comentou como seria esse mundo.

\footnotetext{
1 Professor-Titular do Departamento de Psicologia, Centro de Filosofia e Ciências Humanas, UFSC. Editor da Revista de Ciências Humanas. Endereço para correspondências: Universidade Federal de Santa Catarina, Departamento de Psicologia, Campus Universitário, Florianópolis, SC, 88040-900 (rfguerra@cfh.ufsc.br).

2 Professor-Titular aposentado do Departamento de Engenharia Mecânica, Centro Tecnológico, UFSC. Membro da Academia Nacional de Engenharia (arno.blass@gmail.com).
} 


\section{HUMANAS}

Ele postulou que o desejo de domínio da natureza é parte essencial do ser humano, o que explica o nosso fascínio pelas novidades tecnológicas.

A sua imaginação vislumbrava que os livros seriam escritos em folhas delgadas de alumínio, material não deteriorável e imune à ação das traças e cupins. O petróleo e o carvão seriam substituídos pela energia hidráulica e a moeda corrente seria o kilowatt, útil nas compras e no pagamento dos assalariados; o uso primitivo do petróleo só seria lembrado nos livros de história. Seus comentários foram publicados na primeira edição da edição da revista O Cruzeiro (10 de Novembro/1928).

Não satisfeito com a descrição dos novos artefatos, Laboriau atreveuse a mencionar os costumes do cidadão do novo milênio. Em razão do uso intenso da energia elétrica, o que de fato ocorreu, a luz artificial libertaria o homem dos ciclos determinados pela luz solar. A extinção do ciclo dia e noite promoveria uma maximização da produção industrial e surgiriam novas formas de entretenimento e de afazeres. Os passeios e as viagens desapareceriam, pois as imagens oferecidas pela televisão permitiriam o tour sem sair do sofá - "não há mais necessidade de viajar, para ver terras longínquas: é só ligar o receptor, e visita-se commodamente, qualquer museu, ou qualquer paiz. Somente os objectos devem ser transportados".

O cérebro de Laboriau era uma usina de idéias, mas suas espantosas profecias se distanciaram da realidade: cupins e traças ainda se alimentam da celulose dos livros, o petróleo ainda é uma commodity valiosa, ninguém recebe kilowatts como salário e a iluminação elétrica não libertou o Homo sapiens dos ciclos de sono e vigília - trabalhamos de dia, dormimos à noite. Por mais que gostemos do Discovery Channel, as imagens de TV não substituem o deleite sensorial de uma visita ao Louvre e o tour às pirâmides do Egito.

Por outro lado, Laboriau deu um tiro certeiro ao antecipar o surgimento da Internet e do comércio online: "Não há necessidade de sair para fazer compras: vê-se, escolhe-se, encommenda-se tudo pelo telephone-televisor automático". Antes de qualquer crítica às extravagantes profecias de Laboriau, é preciso ter em mente o enorme salto que ele dera, do ano 1928 para o 2000. Outro detalhe interessante sobre esse amante das inovações tecnológica foi a sua morte, ocorrida em 3 de Dezembro/1928 num acidente aéreo - ele tinha 43 anos e estava num hidroavião que ia ao encontro de um transatlântico, na Baia da Guanabara. 
Grupo Sul e a Revolução Modernista em Santa Catarina

\section{O fascínio tecnológico}

As idéias de Ferdinando Laboriau revelam o fascínio pelas inovações tecnológicas, mas as novas teorias científicas também contaminaram poetas e romancistas, como Augusto dos Anjos e Euclides da Cunha. Esse consórcio intelectual é ainda mais evidente entre os escritores que se dedicam ao gênero sci-fi, como Jules Verne (Viagem ao centro da Terra, 1864), H.G. Wells (A guerra dos mundos, 1898), Aldous Huxley (Admirável mundo novo, 1932), George Orwell (1984; 1949), Isaac Asimov (Eu, robô, 1950) e Arthur C. Clarke (2001: uma odisséia no espaço, 1968).

Intelectuais e as mentes mais esclarecidas do início do século 20 não ignoravam, é claro, as mudanças que ocorriam no mundo. Os novos artefatos e as descobertas científicas (e.g., vacinas e antibióticos) tornavam a vida mais confortável e mais segura, principalmente para o homem que vivia nas cidades. A valorização da vida urbana pode ser facilmente constatada nas antigas histórias em quadrinhos (comic books), onde personagens dotados de super-poderes lutam incessantemente contra alienígenas em defesa da Terra e dos nossos costumes. Por outro lado, muitos escritores e intelectuais exibiam uma atitude diametralmente oposta a esse difuso fascínio futurístico.

O cinema estava dando seus primeiros passos, mas as cenas em pretoe-branco dos filmes causavam admiração. O cineasta alemão Fritz Lang (18901976) dirigiu o que muitos consideram o melhor filme de ficção científica já realizado (Metrópolis, 1927), obra que ressalta a desumanização do homem diante dos avanços tecnológicos e o aumento populacional nas grandes cidades. Charlie Chaplin (1889-1977) também não demonstrava nenhum encantamento com as aglomerações urbanas. Ele denunciou os efeitos da automação na vida dos operários; o tom pessimista deu origem a duas obras clássicas da cinematografia: Luzes da cidade (1931)e Tempos modernos (1936).

Os modernistas caminhavam em outra direção, pois eles exibiam certo fascínio pela vida nas grandes cidades. Com efeito, o poeta Guilherme de Almeida (1890-1969) não economizou palavras ao enaltecer a pujança desenvolvimentista da cidade São Paulo. Seus comentários também foram publicados na histórica edição de $O$ Cruzeiro. O progresso da capital paulistana pode ser visto de cima para baixo, no dorso de um Pégaso imaginário (um aeroplano). Os pessimistas padecem de um estrabismo ou daltonismo crônico e essas enfermidades impedem que, diz o poeta, os neurastênicos enxerguem corretamente algo disposto a um palmo diante do nariz. 
O raciocínio de Guilherme de Almeida é colorido. Ele se queixava daqueles que vêem apenas a coloração cinzenta da maior metrópole brasileira: cinza é a cor da garoa, dos asfaltos, dos telhados e até dos cérebros dos "poetas estrábicos". São Paulo constrói casas de duas em duas horas, ergue-se em alturas assombrosas e por todos os lados se vêem a cor do trabalho (i.e., a cor dos tijolos e das estradas abertas pelos tratores). Para os pessimistas, São Paulo é melancólica e tem a cor cinza do tédio, mas a mudança do olhar pode dar surgimento a outra impressão:

$$
\begin{aligned}
& \text { Mas - ah! - o ponto de vista desses Jeremias } \\
& \text { daltônicos do Parnaso é baixo demais para es- } \\
& \text { tas colinas históricas espetadas de fura-céos. } \\
& \text { Pégaso, que elles cavalgam quando querem des- } \\
& \text { cortinar, julgar e lamentar, está velho e pesado: } \\
& \text { o seu vôo parnasiano não passa da primeira } \\
& \text { cornija de granito da cathedral gothica... Se, em } \\
& \text { vez do cansado Bucephalo alado, tivessem a } \\
& \text { coragem e o espírito de domar um avião, e, prin- } \\
& \text { cipalmente, se não fossem assim tão vesgos, ao } \\
& \text { olharem, lá de cima, de uma altura sufficiente- } \\
& \text { mente moderna, a sua cidade cá embaixo, de } \\
& \text { certo mudaram de opinião. E se possível a um } \\
& \text { ser tímido e rachitico ficar alegre a } 800 \text { metros } \\
& \text { de altura, teriam os bons hypocondriacos um } \\
& \text { sorriso claro de satisfação. Curados do seu dal- } \\
& \text { tonismo e da sua neurasthenia, ficariam saben- } \\
& \text { do que São Paulo não é cinzento: São Paulo é } \\
& \text { vermelho. De um vermelho fosco de tijolo ( } O \\
& \text { Cruzeiro, } 10 \text { de Novembro/1928). }
\end{aligned}
$$

A construção desenfreada de fura-céos, os bondes nas ruas e a crescente massa de trabalhadores, vindos das zonas rurais em busca da realização do sonho urbano, provocavam admiração na alma modernista. A transformação da acanhada São Paulo numa metrópole civilizada foi algo positivo e desejável, mas o processo deu surgimento a uma cidade hiperdimensionada e cheia de problemas. $O$ delírio modernista deve ser entendido à luz das inovações científicas e tecnológicas que marcaram o início do século 20. As atuais metrópoles são corpos inchados de pessoas, onde o cidadão comum vivencia os piores problemas do adensamento urbano 
(i.e., poluição ambiental, congestionamentos de veículos e a desumanização do indivíduo). Uma lição a ser extraída do devaneio modernista: cuidado com seus sonhos - eles podem se transformar em realidade!

Os intelectuais que examinam a história do modernismo ressaltam o seu aspecto renovador e o espírito iconoclasta dos pioneiros. Entretanto, o modernismo sofreu influência do futurismo e dos avanços científicos e tecnológicos da época. A última parte da obra do escritor Leon Tolstoy (Guerra e paz, 1865-69) traz uma interessante discussão sobre os fatores que dão surgimento às guerras e revoluções. Ele fornece uma explicação original sobre a personalidade dos heróis e o papel que eles desempenham no desenlace de eventos históricos. O russo postulou que uma sociedade é algo bastante dinâmico, os personagens interagem uns com os outros e são produtos dessa interação social. Muitos historiadores vêem Napoleão Bonaparte como o personagem que promoveu profundas mudanças na Europa, mas Tolstoy descreve-o como elemento secundário diante das pressões sociais de seu tempo. Napoleão foi produto da evolução dos acontecimentos, não o fator causal. Caso ele não existisse, as mudanças ocorreriam de qualquer modo, pois outros personagens ocupariam o seu papel.

\section{Origens do modernismo}

Nos primeiros anos do século 20 já existiam escritores e artistas prémodernistas (DE AZEVEDO, 1950; COSTA, 1967). Nada surge no vácuo. A tendência pré-modernista pode ser vista na poesia cientificista de Augusto dos Anjos (1884-1914) e no estilo renovador e voltado para as causas sociais de Graça Aranha (1868-1931). Entre os renovadores da literatura também sobressaem Euclides da Cunha (1866-1909) e Monteiro Lobato (18821948); o primeiro fez um relato impressionante sobre a guerra de Canudos, o outro criou personagens e conceitos, como o Jeca Tatu e o "caboclismo"imagem fantasiosa que muitos escritores e poetas tinham sobre a Arcádia rural. Lobato fala mal da idealização da vida rural, mas a sua literatura infantil deu vida a algo ainda mais fantasioso: o reino encantado de Narizinho.

Os antigos modernistas exibiam uma atitude dúbia e contraditória em relação aos avanços científicos e tecnológicos. O movimento era essencialmente urbano e seus adeptos não se cansavam de enaltecer o progresso material das grandes cidades. A capital paulistana passava por um processo de modernização, 


\section{HüMANAS}

a massa de imigrantes gerava novos anseios e a cada dia surgiam novos artefatos. Essas coisas eram valorizadas e promoviam verdadeira revolução nos costumes (ver OLIVEIRA, 1987; FERREIRA, 1992; PINTO, 2001). Os modernistas do início do século 20 eram movidos pelo desejo de promover profundas mudanças no país, mas também buscavam uma nova linguagem literária:
A ambição do grupo (modernista) era grande: educar o Brasil, curá-lo do analfabetismo letra- do, e, sobretudo, pesquisar uma maneira nova de expressão, compatível com o tempo do cine- $\mathrm{ma}$, do telégrafo sem fio, das travessias inter- continentais (BOAVENTURA, 2006; p. 5-6).

O homem "moderno" morava nas grandes cidades, espremia-se em bondes lotados e se encantava com as rápidas transformações no cenário urbano. Nomes das revistas da época também revelam algo sobre esse fascínio tecnológico: Fon-Fon (onomatopéia que designa o som emitido pelas buzinas dos antigos calhambeques) e Kodak (marca de câmeras e equipamentos fotográficos inventados pelo americano George Eastman); o nome da revista Klaxon foi inspirado na marca de um invento sonoro, patenteado por F.W. Lovell (1908) e que posteriormente foi largamente utilizado para designar as buzinas, tal como a marca Xerox que atualmente é quase sinônimo de fotocopiadora.

A construção de prédios, o barulho dos calhambeques e os novos artefatos domésticos suscitavam pensamentos positivos acerca da vida nas cidades. O progresso material era racional e disciplinado, mas os modernistas postulavam que o homem deveria se libertar dos grilhões da lógica e da razão: a alma ou a verdadeira essência do ser humano só se manifesta através dos sonhos, ações inconscientes ou da subjetividade. Enquanto que a psicologia behaviorista lutava para se perfilar ao lado das ciências naturais, longe do subjetivismo, os modernistas valorizavam o progresso material e, contraditoriamente, entendiam que os recônditos da alma deveriam ser explorados para a compreensão total do homem.

Quem mais influenciou os antigos modernistas foi o criador da psicanálise, o médico austríaco Sigmund Freud (1856-1939). Em seu Manifesto antropófago (1928), Oswald de Andrade menciona três vezes o nome de Freud, 
com especial atenção ao livro Totem e tabu (1913). Apesar de curto (duas páginas), o modernista ainda encontra espaço para mencionar perorações marxistas, a luta de classes e dizer aos seus leitores que "alegria é a prova dos noves". Em 1946, o escritor Otto Maria Carpeaux (1900-78) chegou a profetizar que o século 20 seria conhecido pelos historiadores como "o século do inconsciente" (FACCHINETTI, 2003), mas atravessamos com folga todo o século e o que mais se destaca foi o domínio do átomo, a decodificação do genoma humano e as técnicas que permitem a visualização do cérebro em atividade ("a era do cérebro"). O desacerto de Carpeaux é ainda mais acentuado se levarmos em conta que o vaticínio foi lançado após ter ele percorrido quase a metade do século 20 .

É um equívoco alegar que somente a subjetividade seja o caminho para a compreensão da alma humana. Com efeito, o que é aparentemente ilógico ou caótico não significa que não possa ser objeto de uma investigação cientifica - i.e., o que é "subjetivo" logo é transformado em algo "objetivo", tal como fizera Dr. Freud em relação ao funcionamento do aparelho psíquico. A subjetividade é apenas um objeto de estudo da psicanálise e da moderna psicologia cognitiva, mas seus métodos de investigação e a exposição dos resultados não têm nada de subjetivo. $O$ objetivo do empreendimento científico é a busca de relação de causa e efeito ou a elucidação do mecanismo causal. Como diz o Dr. Pangloss, inesquecível personagem de Voltaire, não existe efeito sem causa.

A ciência e a tecnologia promoveram enormes transformações no cenário urbano e o modernismo e seu parente próximo, o futurismo, se inspiraram nessas transformações. A influência é visível na arquitetura, design de utensílios domésticos e de automóveis, cartoons e histórias em quadrinhos. A associação entre as duas tendências deixou marcas na construção de Brasília e nos inúmeros prédios espalhados pelo país. As linhas e as formas geométricas da arquitetura modernista são mais compatíveis com a simplicidade lógica e uso racional do espaço. $O$ prazer contemplativo nada tem de subjetivo, pois atende aos postulados da teoria da percepção (gestalt).

\section{O surgimento do modernismo}

Nas primeiras décadas do século 20, o modernismo era uma tendência ainda difusa e era mais uma reação dos jovens intelectuais contra o formalismo acadêmico do "parnasianismo oficial" (JUNKES, 1982). 


\section{HUMANAs}

Os eventos precursores do modernismo no Brasil são razoavelmente bem estabelecidos, como a exposição que o pintor Lasar Segall (1891-1957) fizera em São Paulo e Campinas (1913) e a publicação do livro O pirralho (1915) de Oswald de Andrade, ocasião em que ele postula a necessidade de desenvolvimento de uma pintura genuinamente brasileira. Outro importante momento pré-modernista foi a exposição de pinturas que Anita Malfatti fizera justamente no ano da Revolução Russa (1917); ela era composta por 53 quadros, entre os quais $O$ farol, $O$ japonês e $O$ homem amarelo.

O marco mais importante do modernismo no Brasil foi a "Semana de Arte Moderna", que ocorreu no Teatro Municipal de São Paulo (11 a 18 de Fevereiro/1922). Foram realizadas exposiçð̃es de artes plásticas, conferências, concertos musicais e recitais de poesias. O evento contou com o apoio dos "barões do café", magnatas que residiam nos palacetes da Avenida Paulista, e foi inaugurado por uma conferência ministrada por Graça Aranha (18681931). Na ocasião, ele proclama a importância do modernismo, embora poucos tenham compreendido o significado de sua fala; dois anos depois e na Academia Brasileira de Letras, Graça Aranha declara que a própria academia estaria condenada à morte, porventura ignorasse os ventos renovadores da nova tendência - as duas conferências foram aglutinadas no livro $O$ espirito do moderno (1925). O grave vaticínio do influente escritor foi outro tiro n'água, pois os antigos intelectuais da academia praticamente ignoraram os ventos modernistas, como ocorreu em Santa Catarina, e a ABL continuou funcionando a todo vapor.

O ano da "Semana de Arte Moderna" também foi o momento de comemoração do centenário da independência do Brasil (1822-1922). Como intuito de promover uma maior integração entre Portugal e Brasil, os aviadores Gago Coutinho e Sacadura Cabral realizam a primeira travessia aérea do Atlântico Sul, feito largamente noticiado pelos jornais dos dois países. $\mathrm{O}$ desejo de Portugal de se aproximar do Brasil também deu origem à monumental História da colonização portuguesa no Brasil, obra em três volumes organizada pelo historiador Carlos Malheiros Dias (1922).

Não obstante todos esses esforços, o discurso de GraçaAranha, proferido na Academia Brasileira de Letras (1924), recomendava o afastamento da excolônia em relação à Portugal: a unidade não é desejável e a separação deveria ser alargada (ver SOUZA, 2008). A recomendação do influente escritor contrasta com as tentativas de unificação do código ortográfico das naçőes de língua portuguesa, defendido pela ABL. Quem rejeita a aproximação agora é Portugal. 
O ano 1922 também foi marcado por outros episódios tão importantes, quanto contrastantes, como a rebelião tenentista e a criação do Partido Comunista. A inauguração da "Semana de Arte Moderna" aumentou ainda mais a ebulição ideológica daqueles tempos, o que promoveu uma reação da elite conservadora. Esse pessoal alegava que o Brasil era uma nação católica, mas deveria ser recatolizado para enfrentar o materialismo e a baderna produzida pelos espíritos revolucionários. É nesse contexto que surge a revista católica A Ordem (1921) e, no ano seguinte, é fundado o Centro Dom Vital (OLIVEIRA, 1987).

No mesmo ano da realização da "Semana de Arte Moderna", surge a revista Klaxon (Maio/1922) e Mario de Andrade publica Paulicéia desvairada (1922), obra cujo texto "Prefácio interessantíssimo" traz uma discussão sobre as bases do modernismo. Um pouco mais tarde, Oswald de Andrade lança o seu conhecido Manifesto antropófago (1928), onde ele sugere que "devoremos" a cultura estrangeira para a criação de uma nova e genuína forma de expressão artística.

A "Semana de Arte Moderna" deixou sua marca indelével na sociedade paulistana e gradativamente contaminou o restante do país. Levando em conta a data de nascimento e o ano em que foi realizado o evento (1922), notamos que a maioria dos modernistas de primeira hora tinha menos de 30 anos de idade, como Sergio Milliet (1898-1966), Emiliano Cavalcanti, o Di Cavalcanti (1897-1976), Guiomar Novaes (1894-1979), Victor Brecheret (18941955), Menotti del Picchia (1892-1988) e Ronald de Carvalho (1893-1935); Mario de Andrade (1893-1945), que liderara espontaneamente o movimento, tinha 28 anos. Os mais "velhos" tinham pouco mais de trinta anos, como Guilherme de Almeida (1890-1969), Oswald de Andrade (1890-1954), Heitor Villa Lobos (1887-1959); Tarsila do Amaral (1886-1973) era a musa do modernismo e tinha 35 anos quando o vulcão modernista entrou em atividade.

Alguns intelectuais conhecidos emprestaram seu prestígio para a deflagração do movimento, entre os quais o próprio Graça Aranha e Paulo de Almeida Prado (1869-1943), quem convencera os "barões do café" a abrirem as arcas para financiar a realização da semana modernista. Como seria de se esperar, a tranqüila e provinciana sociedade paulistana exibiu certa simpatia em relação às novidades do mundo das artes, mas preponderou o sentimento de perplexidade; alguns julgaram que a produção dos modernistas não poderia sequer ser classificada como arte. Os populares não gostaram da conferência ministrada por Mario de Andrade, o que ocasionou tumultos e vaias. 


\section{HUMANAS}

Também houve reação desfavorável em relação à exposição de artes plásticas: alguns xingavam, davam bengaladas ou tentavam destruir obras dos pintores modernistas.

Até hoje persistem duvidas em torno da gênese do movimento modernista. Com alguma falta de modéstia, Mario de Andrade postulou que o modernismo foi o "prenunciador, o preparador e por muitas partes o criador de um estado de espírito nacional". (ver FACCHINETTI, 2003), mas o movimento foi fruto das inquietações daqueles tempos (zeitgeist). Ele também postulou que, como espírito dominante e criador de novas tendências, 0 modernismo teve vida curta, pois morreu em 1930 a partir da revolução política e "pacificação literária"(COSTA, 1967).

Alguns scholars parecem acreditar que o modernismo surgiu no vácuo ou não dão a devida importância às figuras relativamente eclipsadas de Graça Aranha e Paulo Prado. O modernismo foi resultante de um estado de espírito e novas preocupações e, com efeito, o próprio Mario de Andrade fornece uma interessante explicação sobre a gênese do movimento:

Quem teve a idéia da Semana da Arte Moderna? Por mim não sei quem foi, nunca soube, só posso garantir que não fui eu. $\mathrm{O}$ movimento, se alastrando aos poucos, se tornara um escândalo público permanente. Já tínhamos lido nossos versos no Rio de Janeiro; e numa leitura principal, em casa de Ronald de Carvalho, onde também estavam Ribeiro Couto e Renato de Almeida, numa atmosfera de simpatia. Paulicéia desvairada obtinha o consentimento de Manuel Bandeira, que em 1919 ensaiara os seus primeiros versos livres no Carnaval. $\mathrm{E}$ eis que Graça Aranha, célebre, trazendo da Europa a sua Estética da Vida, vai a São Paulo, e procura nos conhecer e agrupar em torno de sua filosofia. Nós nos ríamos um bocado da Estética da Vida que ainda atacava certos modernos europeus da nossa admiração, mas aderimos francamente ao mestre. E alguém lançou a idéia de se fazer uma Semana de Arte Moderna, com exposição de artes plásticas, concertos, leituras de livros e conferências explicativas. 
Foi o próprio Graça Aranha? Foi Di Cavalcanti?... Porém o que importa era poder realizar essa idéia, além de audaciosa, dispendiosíssima. E o fator verdadeiro da Semana de Arte Moderna foi Paulo Prado (In: COSTA, 1967; p. 384).

Alguns ataques ao modernismo partiram de intelectuais respeitados, como J.B. Monteiro Lobato (1882-1948) que escrevera um artigo condenando veementemente o que ele julgava ser apenas "coisa de louco", embora muitos considerem uma de suas obras iniciais (Urupês, 1918) marco importante na história do modernismo. $O$ contraditório escritor pertencia a uma geração anterior e não acreditava nas inovações literárias. O pai de Narizinho descarregou uma série de vitupérios contra os modernistas; a virulência e estilo arrebatado podem ser vistos na classificação que ele fizera dos artistas:

Há duas espécies de artistas. Uma composta dos que vêem as coisas e em conseqüência fazem arte pura, guardados os eternos ritmos da vida, e adotados, para a concretização das emoções estéticas, os processos clássicos dos grandes mestres. Quem trilha esta senda, se tem gênio é Praxiteles na Grécia, é Rafael na Itália, é Reynolds na Inglaterra, é Dürer na Alemanha, é Zorn na Suécia, é Rodin na França, é Zuloaga na Espanha. Se tem apenas talento, vai engrossar a plêiade de satélites que gravitam em torno desses sóis imorredoiros. A outra espécie é formada dos que vêm anormalmente a natureza e a interpretam à luz das teorias efêmeras, sob a sugestão estrábica de escolas rebeldes, surgidas cá e lá como furúnculos da cultura excessiva. São produtos do cansaço e do sadismo de todos os períodos de decadência; são frutos de fim de estação, bichados ao nascedouro. Estrelas cadentes, brilham um instante, as mais das vezes com a luz do escândalo, e somem-se logo nas trevas do esquecimento (LOBATO, 1917). 
Lobato classificou os quadros de Anita Malfatti como "coisas de louco". Ele também argumentou que a arte realizada nos manicômios é sincera, embora seja produto de cérebros convulsionados por "estranhas psicoses", diferentemente das pinturas modernistas que nada mais eram que pura mistificação. As diatribes lobatianas ainda mencionam os "furúnculos mentais" e "almas bichadas" que só conseguem produzir coisas típicas dos manuais de psicopatologia; o "estrabismo das escolas rebeldes" explica a arte estranha, mas o poeta Guilherme de Almeida recorreu aos distúrbios visuais para explicar exatamente o oposto: são os vesgos e os portadores de daltonismo crônico é que não conseguem vislumbrar o valor da arte moderna. Não obstante a descrição sobre o estranho modo de funcionamento dos órgãos sensoriais, o malabarismo estilístico aproxima Lobato dos modernistas.

Os modernistas expressavam suas idéias de modo diferente e combatiam o estilo formal dos antigos intelectuais, como o romantismo de José de Alencar, a "lábia" do Padre Vieira ou o lado doutor e das citações de certos luminares, como o jurista Ruy Barbosa. Essas críticas são mencionadas nos textos Manifesto pau-brasil (Correio da Manhã, 18 de Março/1924) e Manifesto antropófago (Revista de Antropofagia, Maio/ 1928), ambos produzidos por Oswald de Andrade. Os dois manifestos não consomem mais que duas páginas, mas exigem especial atenção dos leitores, em razão do estilo rebuscado e pedante. Entretanto, um modernista importante acabou sendo seduzido pelo "lado das citações". Trata-se de Mario de Andrade, autor de dois livros de certo valor científico: Namoros com a medicina (1937) e Música de feitiçaria (1933; publicado postmortem em 1957).

O crítico Edgar Cavaleiro enalteceu a importância da primeira obra, valorizando o amadurecimento da linguagem de Mario de Andrade: era confusa, cheia de cacoetes, mas agora é segura e lógica. O poeta começou com estilo "descabeladamente moderno, usou e abusou dos cacoetes, complicando em vez de simplificar. Mas, com o decorrer do tempo, foi deixando o que havia de forçado e artificial... e nos últimos tempos, sua prosa atingia tal grau de cristalinidade e pureza, tal plasticidade e sabor, que dificilmente imaginaríamos escondesse a língua que falamos tão fartos recursos".

Os comentários de Cavaleiro enaltecem a obra de Mario de Andrade, mas trazem implícito uma grave crítica: o modernista só amadureceu quando passou a fazer uso da lógica e das citações, o que permitiu maior fundamentação e cristalinidade na expressão de seus pensamentos e idéias. 
Surge uma pergunta: o modernismo, em seu estágio inicial, era composto por jovens confusos ou gênios precoces?

\section{O modernismo em Santa Catarina}

Nas primeiras décadas do século 20, Florianópolis era uma cidadezinha atrasada e imersa em si mesma, diferentemente do atual paraíso que tanto encanta a geração dourada do surfe. O nome anterior era Ilha do Desterro, designação que lembra algo isolado, longínquo ou local destinado aos elementos expulsos da sociedade. A mudança de nome ocorreu em $1894 \mathrm{e}$ serviu para homenagear o presidente Floriano Peixoto (1839-95), militar que mandou fuzilar quase duas centenas de catarinenses na Ilha de Anhatomirim. Desterrenses quatrocentões não apreciam nem um pouco a homenagem e tampouco se sentem confortável com encurtamento licencioso do nome da cidade-Floripa.

Por mais de duas décadas Santa Catarina se manteve refratária às influências modernistas que emanavam de São Paulo. Várias razões têm sido arroladas para justificar esta postura. A principal delas reside na conviç̧ão realista/parnasiana preponderante na maioria da intelectualidade catarinense da época, em que se destacava a personalidade forte de Altino Corsino da Silva Flores (1892-1984). Usando como trincheira a revista Terra, que circulou entre Março/1920 e Janeiro/1921, e da qual fora o seu editor-chefe, Flores desenvolveu uma pregação sistemática contra as idéias modernistas (SABINO, 1979; CASTELLI, 1982; CORREA, 1999).

Altino Flores não gostava nem um pouco dos jovens modernistas, os quais, segundo o seu entendimento, "acasalavam espantosa ininteligência com lastimável falta de educação". Ele não vislumbrava futuro alvissareiro para a "literatura novíssima" e não perdia oportunidade para denunciar a "incrível falta de qualidades literárias" do rapazio modernista. As desavenças não se limitavam ao mundo das idéias, uma vez que o influente jornalista usou de seu prestígio para fechar as portas do jornal $O$ Estado aos membros do "famigerado" Círculo de Arte Moderna (JUNKES, 1982).

A dimensão reduzida da intelligentsia catarinense da época, as dificuldades de comunicação entre os vários centros culturais, o virtual autodidatismo dos intelectuais e a inexistência de casas editoras também serviram para truncar o acesso a novas idéias ou novas formas de criação artística. É sintomático que a Academia Catarinense de Letras, embora criada em 1920, 
tenha vegetado durante muito tempo, sem conseguir completar seu quadro ou editar uma revista. Somando-se a tudo isso, como ressaltou Carlos Humberto Correa em recente entrevista concedida à Revista de Ciências Humanas, a implantação da ditadura do Estado Novo deixou a intelectualidade catarinense esfacelada (ver GUERRA, 2008).

É neste cenário que, por volta de 1948, surge o movimento modernista em Santa Catarina, representado pelos jovens que se congregaram no Círculo de Arte Moderna (CAM). Eles eram majoritariamente egressos do Colégio Catarinense de Florianópolis, onde foram alunos de um certo professor que amava as artes. Os jovens modernistas buscavam espaço para vazão da produção literária, mas encontravam dificuldades, devido aos poucos jornais existentes e à natureza de suas propostas - eles queriam "abalar a pasmaceira da ilha"!

Eles se reuniam à sombra da frondosa figueira da Praça $\mathrm{XV}$ ou discutiam assuntos literários no Café Rio Branco, conhecido bar que ficava no final da rua Felipe Schmidt. De início, os jovens do CAM começam a aparecer nas páginas do periódico Folha da Juventude, que circulou entre Novembro/1946 e Agosto-Setembro/1947, num total de seis números (SABINO, 1979). A partir do terceiro número ela passou a ser dirigida por Antonio Paladino, tendo Ademar Américo Madeira como redator-chefe. Paladino foi um dos integrantes originais do CAM. A Folh a da Juventude era aberta a todas correntes literárias, mas passou a publicar cada vez mais as matérias dos integrantes do CAM; ela tinha uma página de arte moderna que era dirigida por Aníbal Nunes Pires.

O modernismo surgiu a partir dos encontros fortuitos dos ex-alunos do Colégio Catarinense e, após tantos anos, aquelas tertúlias literárias continuam a influenciar os corações e as mentes. O sucesso do movimento indubitavelmente se deve ao dinamismo e capacidade intelectual de dois personagens: Aníbal Nunes Pires (1915-78) e Salim Miguel (1924). Eram duas personalidades bem diferentes, mas mutuamente complementares.

Aníbal desempenhou um papel fundamental para a consolidação do grupo, pois era professor respeitável e pertencia a uma família tradicional. Ele foi uma espécie de mentor que, generosa e gentilmente, estimulava vocações literárias de seus alunos secundaristas; a simples presença de Aníbal proporcionava respeitabilidade ao grupo. Salim Miguel era cerca de 10 anos mais jovem que Aníbal, diferença etária bastante significativa quando se fala 


\section{Grupo Sul e a Revolução Modernista em Santa Catarina}

de pessoas em plena flor da mocidade. Ele foi o mais produtivo de todos e sua influência literária ultrapassa as fronteiras do nosso estado. Aconchegados numa espécie de ninho parental, o jovem libanês começou a se movimentar mais intensamente e, junto com os demais membros do que viria a ser o Grupo Sul, ganhou maturidade e deslanchou na carreira literária. Aníbal foi o elemento mais importante para o desabrochar e os primeiros passos do modernismo em Santa Catarina, mas Salim espontaneamente se tornou o "moderno" mais influente do grupo.

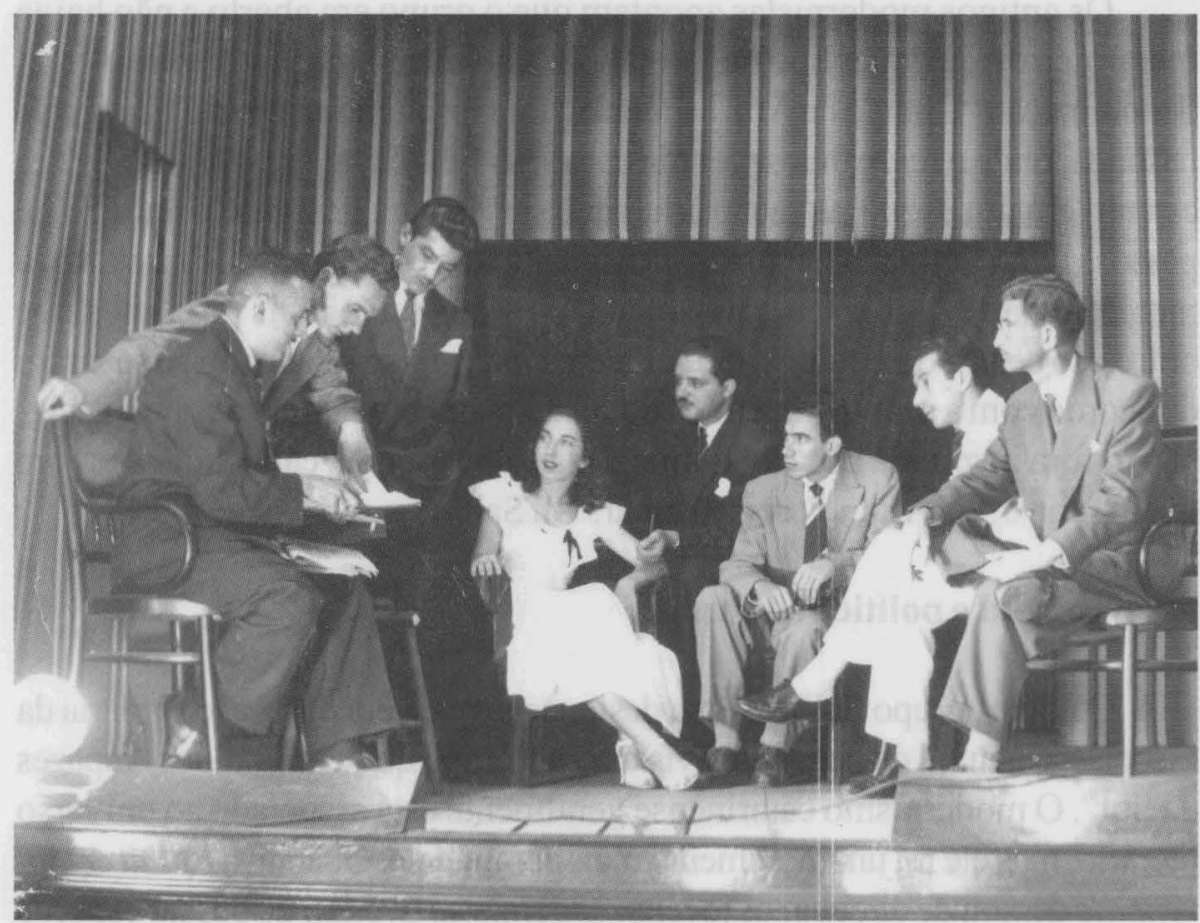

Figura 1

Ensaio teatral dos integrantes do então Círculo de Arte Moderna. A partir da esquerda: Aníbal Nunes Pires, Ody Fraga e Silva, Jason Cesar, Eglê Malheiros, Salim Miguel, Walmor Cardoso da Silva, Armando Carreirão e Archibaldo Cabral Neves.

A relembrança dos tempos do CAM revela coisas interessantes. Salim é uma figura reverenciada no mundo da literatura, mas ele não chegou a concluir o curso Clássico (equivalente ao $2^{\circ} \mathrm{Grau}$ de nossos dias), afugentado pela matemática. Aníbal, seu professor no Colégio Catarinense, 
fez de tudo para lhe inculcar os rudimentos da matéria, mas em vão. Salim terminou reprovado e interrompeu seus estudos, sem concluir o segundo grau. Por outro lado, os alunos gostavam de Aníbal; ele exibia pendores para as artes e procurava mostrar-lhes o componente poético da matemática. Salim achava-a intragável! A proximidade do professor com os jovens modernistas causava certa consternação aos seus colegas e aos dirigentes do vetusto Colégio Catarinense. Os depoimentos que virão a seguir mostram os problemas que ele enfrentou em decorrência de seu envolvimento com eles.

Os antigos modernistas apontam que o grupo era aberto e não havia hierarquia ou qualquer tipo de formalidade no relacionamento entre eles. A denominaçăo "Círculo de Arte Modema" fora inspirada na mitológica távola redonda, onde o rei Arthur se reumia com seus fiéis cavaleiros. A idéia de um círculo era um esquema metafórico que servia para designar a reunião de pessoas iguais num ambiente re fito (igualdade e completude). Entretanto, a metáfora não é plenamente adequada, poís uns estão mais próximos que outros do centro do círculo e os elementos internos se juntam ou se separam de acordo com a própria dinâmica do relacionamento. Uma vez que a designação fora inspirada nos cavaleiros da távola redonda, cabe indagar sobre quem seria o "rei Arthur": seria Aníbal? Ou Salim?

\section{A revista Sul e política editorial}

O nome "grupo Sul" foi uma designação que veio de fora, originária da associação natural do nome da revista com o grupo que a dirigia - os "rapazes da Sul". O modernismo catarinense geralmente está associado ao universo literário, mas ele foi um movimento mais abrangente. Quando a Folha da Juventude deixou de circular, os jovens modernistas tiveram de buscar espaços alternativos para dar vazão a sua produção literária. E como eles queriam avançar ainda mais, o desejo de criar uma revista logo se instalou. A falta de dinheiro para tanto foi solucionada com outro empreendimento cultural, a encenação de um espetáculo teatral. O episódio revela que o embrião do modernismo catarinense já era possuído por abrangentes pretensões artísticas, não circunscritas ao universo literário. É o próprio Salim que descreve:

Ody Fraga e Silva sugeriu que montássemos um espetáculo teatral, com três peças em um ato. Numa delas, "O homem da flor na boca", 
de Pirandello, lá estávamos o Aníbal Nunes Pires e eu, ambos sem nenhuma vocação para o palco, eu tímido e desajeitado, o Aníbal de voz rouca e falando para dentro. $O$ importante foi o resultado, as três peças: "Como ele mentiu ao marido dela", de Bernard Shaw, "As estátuas volantes", de Jean-Paul Sartre e a já citada, de Luigi Pirandello, tendo estreado em 7 de novembro de 1947 , lotaram o teatro por duas noites. Além dos dois primeiros números da Revista, a bilheteria possibilitou um jantar comemorativo no Lira Tênis Clube (MIGUEL, 2008; p. 134).

O dinheiro da bilheteria permitiu a criação da revista Sul, para alegria de Aníbal e dos ex-alunos do Colégio Catarinense. A revista se tornou um marco na história da inteligência catarinense, pois ela estimulou o surgimento de novos talentos e consolidou os já existentes, no Brasil e exterior. Do ponto de vista financeiro, ela enfrentou sérias dificuldades e exigia muita criatividade de seus fundadores para não fechar as portas. Sul era colocada à venda em algumas livrarias no centro da cidade, mas despertava pouco interesse. Certa ocasião alguém indagou a Walmor Cardoso da Silva, um dos mais antigos integrantes do grupo, sobre o sucesso do negócio. Ele prontamente respondeu: "- Vai bem. Olha, dos dez exemplares que colocamos à venda, ali, na livraria, acabo de verificar que já tem onze!" (DA SILVA, 2004; p. 7).

Apesar das dificuldades financeiras e despreparo do grupo, pois ninguém tinha experiência editorial, $S u l$ conseguiu sobreviver ao primeiro ano e manteve a pretendida periodicidade (bimestral). O editorial do primeiro número foi escrito por Aníbal e dizia o seguinte: "Sul se propõe, na medida das coisas possíveis, revelar valores novos e acompanhar as idéias do mundo atual". Aníbal foi o primeiro editor e a sua liderança facilitou a aceitação do modernismo na conservadora sociedade florianopolitana.

A revista $S u l$ logo se mostrou um veiculo insuficiente para dar vazão à crescente produção intelectual dos integrantes do grupo Sul (GS) e de seus colaboradores. $O$ formato e a periodicidade irregular eram fatores limitantes e, além disso, os modernistas tinham em mente as críticas que Altino Flores fizera, por ocasião da tentativa de criação da Academia Catarinense de Letras; o jornalista lançou a dúvida: "Onde estão os escritores catarinenses?" 


\section{HUMANAS}

Dizia ele que o cenário cultural era de "escritores sem livros", mas, apesar do terrivel diagnóstico, a ACL foi criada em 1920 e ele próprio se integrou aos seus quadros.

O GS tinha em mente essas críticas e, como tentativa de fugir ao diagnóstico de Altino Flores, desencadeou um ambicioso programa editorial. $\mathrm{O}$ início desse programa foram os Cadernos Sul, publicados a partir de 1949, inaugurando-se a série com Idade 21 , livro de poemas de Walmor Cardoso da Silva. Sete cadernos foram publicados até 1957, incluindo livros de autores não pertencentes formalmente ao GS.

O formato logo se revelou inadequado para obras de maior fôlego, de modo que, a partir de 1951, surgiram as Edições Sul, de que oito livros foram publicados até 1957. Salim Miguel inaugurou o novo empreendimento editorial com seu livro Velhice e outros contos. A qualidade gráfica melhorou bastante, pois o livro de Salim vinha com ilustrações de Edgar Koetz, artista plástico ligado à Editora Globo, de Porto Alegre, e que se encontrava no auge da fama. Além da revista Sul, o programa editorial serviu de plataforma de lançamento para as obras de autores atualmente conhecidos, como o lageano Guido Wilmar Sassi e o ilhéu Adolfo Boos Jr.

Salim Miguel e Eglê Malheiros, modernistas de primeira hora, são casados desde $1954 \mathrm{e}$ foram autores do primeiro longa metragem produzido $\mathrm{e}$ filmado no nosso estado ( $O$ preço da ilusão, 1957). Dois depoimentos esclarecem a importância de Aníbal e Salim para o surgimento e consolidação do movimento modernista catarinense. $O$ primeiro depoimento foi dado por Ernani Bayer, ex-reitor da Universidade Federal de Santa Catarina, e o segundo pertence ao conhecido escritor Silveira de Souza:

Por sua participação ativa durante todo o processo, Aníbal Nunes Pires se destacou. O mais velho do grupo, já formado, lecionando em vários lugares, de família tradicional, não só deu o seu aval (como fizera antes dele Graça Aranha em São Paulo), mas atuou ativamente em todo o movimento. Escreveu, foi ator, orientou, arranjou anúncios para a revista, vendeu edições, sofreu na própria carne preconceitos que em certo momento alcançaram os membros do grupo. Por isso, e porque era um desprendido, 


\section{Grupo Sul e a Revolução Modernista em Santa Catarina}

talvez não seja ressaltada a sua obra, que é pequena em quantidade, a medida exata de seu talento. Prejudicou-se em favor dos outros. Mas sentia-se feliz assim, sabem-no os que com ele conviveram (in: JUNKES, 1982; p. 13).

Às vezes chego a acreditar que talvez o tão discutido Grupo Sul, mesmo com o inegável talento literário de alguns de seus outros componentes, não chegasse a ter o prestígio que tem hoje, se não existisse a presença constante, persistente, articuladora, e não ostensiva, daquele líbano-biguaçuense incansável (DE SOUZA, 2008; p. 4).

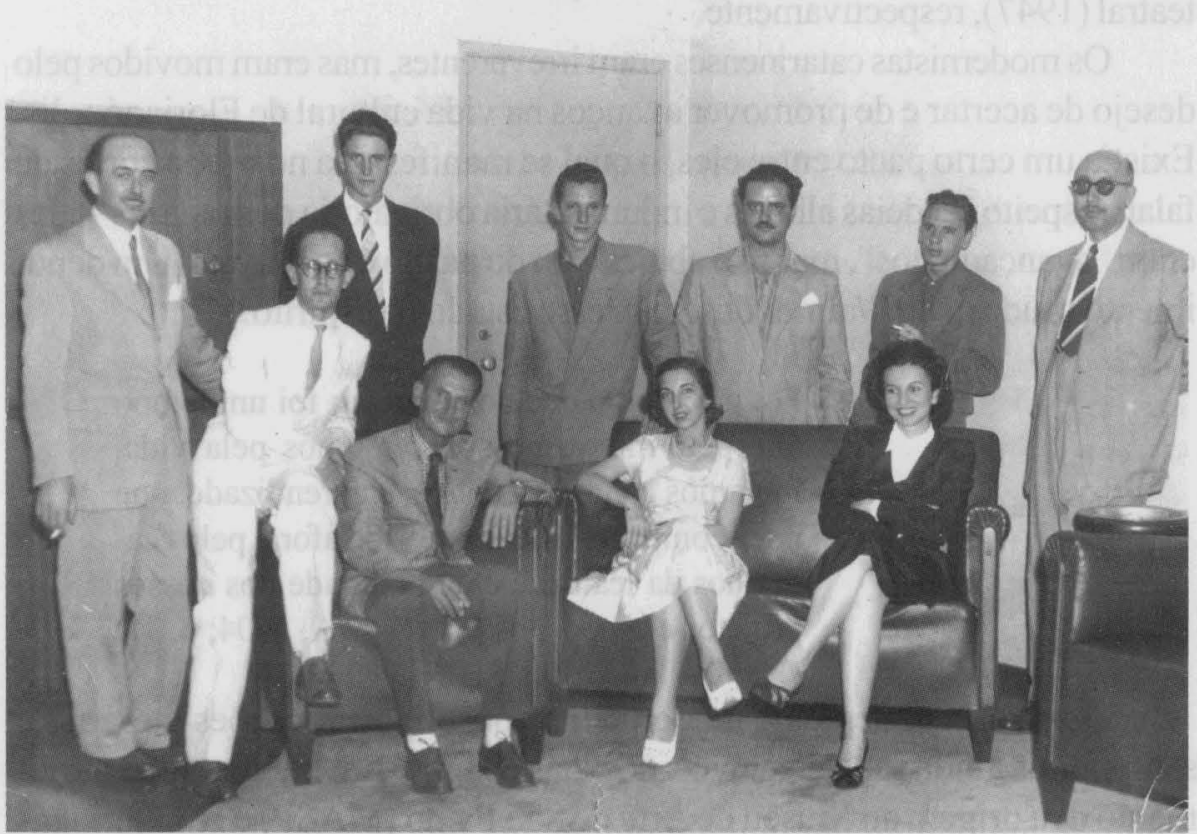

\section{Figura 2}

Visita dos modernistas catarinenses ao Rio de Janeiro. A partir da esquerda: Jorge Lacerda, Carlos Drummond de Andrade (terno branco), Pedro Taulois, Oswaldo Goeldi, Dante Ravaglio, Eglê Malheiros, Salim Miguel, Yedda Navarro, Ody Fraga e Silva e José Simeão Leal. 
O depoimento de Bayer aponta que Graça Aranha e Anibal Nunes Pires desempenharam papéis equivalentes na consolidação do modernismo, em São Paulo e em Florianópolis. Um exame mais atento também revela que a exposição de obras de arte e as conferências realizadas no Grupo Escolar Dias Velho foram uma espécie de reprise da "Semana de Arte Moderna", realizada em São Paulo. Em ambos os casos, os episódios suscitaram reações variadas e contraditórias na população. Entretanto, as semelhanças do movimento modernista paulista e catarinense não param por aí. Os dois movimentos sofreram rejeição por parte dos antigos intelectuais e seus componentes eram jovens com menos de 30 anos de idade, exceto seus líderes naturais, Graça Aranha e Aníbal, que já contavam com mais anos nas costas. Tanto em São Paulo quanto em Florianópolis, os modernistas organizaram um evento para deflagrar ou marcar a existência do movimento - a organização da "Semana de Arte Moderna" (1922) e a encenação de um espetáculo teatral (1947), respectivamente.

Os modernistas catarinenses eram irreverentes, mas eram movidos pelo desejo de acertar e de promover avanços na vida cultural de Florianópolis. Existia um certo pacto entre eles, o qual se manifestava no modo cortês de falar, respeito às idéias alheias e indumentária obrigatória dos rapazes-eles eram "avançadinhos", mas não abdicavam do paletó e da gravata. Um depoimento saudoso de Walmor descreve esse estado de espírito:

Foi um tempo que nos marcou; foi um tempo que determinou nossos caminhos pela vida. Levamos conosco a marca, o aprendizado, que nos acompanham sempre, vida afora, pelos caminhos da lealdade e da liberdade dos nossos projetos e propósitos (DA SILVA, 2004; p. 7).

O amadurecimento do modernismo consolidou vocaçð̃es literárias e seus efeitos ainda são detectáveis nos dias de hoje. Em São Paulo, o movimento deu origem ao Museu de Arte de São Paulo (MASP) e em Florianópolis foi criado algo semelhante, o Museu de Arte Contemporânea (MAC). Anita Malfatti foi a musa dos modernistas paulistas e Eglê Malheiros, a bonita e elegante poeta, inspirou os modernistas catarinenses e acabou se casando com Salim. Outras curiosidades: o jornalista e escritor Altino Flores combateu tenazmente a nova tendência literária, tal como fizera o conhecido escritor e editor Monteiro Lobato em relação aos modernistas de São Paulo. 
O grupo Sul era composto por jovens inteligentes e arrojados e, por motivos misteriosos ou artimanhas do destino, eles repetiam os percalços enfrentados pelos modernistas da matriz paulista.

\section{Quais eram os membros do Grupo Sul?}

Os ventos do modernismo sacudiram Florianópolis. Em razão da revista que publicavam, os jovens do CAM passaram a ser conhecidos como os "rapazes da revista Sul" ou, mais parcimoniosamente, como o Grupo Sul (GS). Os estudiosos do movimento freqüentemente tentam elucidar quais eram os componentes do grupo mencionam, com algum acerto e justiça, que ele era composto, em ordem alfabética, por Adolfo Boos Jr., Aldo Sagaz, Aníbal Nunes Pires, Antonio Paladino, Archibaldo Cabral Neves, Cláudio Bousfield Vieira, Eglê Malheiros, Elio Ballstaedt, Guido Wilmar Sassi, Hiedy de Assis Correa, o Hassis, João Paulo Silveira de Souza, Ody Fraga e Silva, Oswaldo Ferreira de Melo, Salim Miguel e Walmor Cardoso da Silva. Entretanto, não é adequado associar o tempo de vida do GS à existência da revista Sul (1948-57) e, portanto, a lista não é isenta de dúvidas e desacordos.

O modernismo catarinense foi um movimento bastante abrangente no tempo e em suas pretensões artísticas. Alguns modernistas de primeira hora faleceram ou abandonaram o GS no meio do caminho, como ocorreu com Antonio Paladino (1925-50) e Elio Ballstaedt, respectivamente. Os dois abraçaram o movimento em seus estágios iniciais e deram importantes contribuições para o sucesso da revista Sul, mas, desafortunadamente, seus nomes foram eclipsados pelo desenrolar dos acontecimentos. Por outro lado, Guido Wilmar Sassi (1922-2002) é reconhecido como membro genuíno do GS, pois contribuía regularmente com a revista $S u l$, embora residisse em Lages e, mais tarde, tenha fixado residência no Rio de Janeiro. Sassi não participava das reuniões do GS, mas seu espírito morava junto aos modernistas de Florianópolis.

Sul foi um empreendimento que permite fixar o modernismo no tempo e no espaço, mas o espírito modernista já existia antes de sua criação e perdura até os dias atuais - as idéias não nascem espontaneamente, tampouco desaparecem sem deixar vestígios. Além disso, o bonde modernista estava sempre em movimento e dele saltavam ou ingressavam novos passageiros, de modo que os componentes mudavam com o decorrer do tempo. 
Os depoimentos de Salim, Eglê e Walmor revelam que muitas pessoas auxiliavam na condução da revista, mas pouco ou nada publicaram e seus nomes se perderam no tempo. Esses modernistas estavam presentes em todos os momentos, ajudavam no gerenciamento da revista e se envolviam nos debates, mas ninguém associa seus nomes ao GS. Por outro lado, a revista tinha correspondentes que contribuíam regularmente com textos, poesias e ensaios literários; eles ajudaram muito na consolidação do grupo, mas nunca davam as caras. Nesse sentido, até Salim, Eglê e Walmor ficam confusos no momento em que tentam identificar quais eram os verdadeiros integrantes do GS. Seriam aqueles que prestavam ajuda e freqüentavam os debates, sem que tivessem dado alguma contribuição ao engrandecimento da revista Sul? Ou seriam aqueles intelectuais que viviam fora de Santa Catarina e que contribuíam regularmente com a revista, ignorando se estes eram gordos ou magros?

\section{Cineclubismo e as artes plásticas}

O cineclubismo começou de modo tímido por volta de 1949, ainda nos tempos do CAM e envolvendo contatos com Instituto Brasil Estados Unidos (IBEU), que então funcionava em Florianópolis. Foi através desses contatos que os jovens modernistas catarinenses tiveram acesso a filmes de curta metragem e desenhos animados. Uma vez que o IBEU exigia uma organização formal para os empréstimos de longa metragens, logo foi criado o Clube de Cinema do CAM, que mais tarde se transformou no Clube de Cinema de Florianópolis. O objetivo dos empréstimos era ampliar o conhecimento sobre a sétima arte e exibição de filmes que normalmente não seriam exibidos na cidade. As sessões estimulavam os estudos e debates ou serviam como motivo para realização de conferências.

$\mathrm{E}$ foi assim que começaram a ser exibidos e discutidos filmes de Alberto Lattuada, René Clair, John Huston, Charles Chaplin, Maya Deren e de outros diretores famosos. Os empréstimos nem sempre eram fáceis, de modo que o Clube de Cinema "morria e renascia", no dizer de Walmor Cardoso da Silva. O apoio de Paulo Fontoura Gastal, do Cine-clube de Porto Alegre, foi muito importante, pois ele estava envolvido há mais tempo em tais atividades e emprestou a sua experiência e seus contatos para o 
sucesso do empreendimento catarinense. Em comemoração ao primeiro aniversário do cine-clube, o CAM teve sucesso no pedido de empréstimo de quatro filmes do cineasta italiano Enrico Gras, cedidos pela filmoteca do SODRE (Servicio Oficial de Difusión, Radiotelevisión y Espectáculos, do Uruguai).

Das discussões sobre cinema-arte resultou a intenção de rodar um filme de longa metragem em Santa Catarina. Com uma equipe mista, integrada de teóricos e profissionais, Armando Carreirão criou a Sul Cine Produções e levantou recursos por meio de financiamento bancário e subscrição de cotas. Com roteiro de Salim Miguel e Eglê Malheiros, foi rodado o filme $O$ Preço da Ilusão (1957), fortemente influenciado pelo neo-realismo italiano de pósguerra. Mas por problemas na montagem, realizada em São Paulo, o filme não correspondeu às expectativas.

O filme desapareceu e hoje só restam os oito minutos finais. Adolfo Boos Jr. nos fornece uma explicação para o insucesso do primeiro longa metragem genuinamente catarinense: “o filme até era bom, mas foi montado de modo completamente errado e sem supervisão, o que explica o seu fracasso - eles pagaram o "preço da inexperiência". Infelizmente, nada de significativo foi produzido em seguida, exceto documentários eventuais"(ver mais detalhes na seção Depoimentos).

Em seus primeiros números, a revista $\mathrm{Sul}$ prestigiou artistas externos em suas capas (Fayga Ostrower, Iberê Camargo, Alexander Calder e Bruno Giorgi, entre outros). Logo a revista emprestou espaço para a divulgação de gravuras e desenhos de artistas locais. Entre os gravuristas, ali apareceram Dimas Rosa e Aldo Nunes; entre os desenhistas, surgiram Hassis, Orlando Ferreira de Mello, Martinho de Haro, Meyer Filho, Tércio d'Ávila e outros. No corpo da revista as artes plásticas foram tema de artigos e entrevistas. O GS promoveu também conferências e debates sobre o assunto, destacando-se a Exposição de Gravuras Brasileiras (1954), que ocorreu nas dependências do Lux Hotel. Foi nessa ocasião que o renomado artista Carlos Scliar ministra um curso de artes plásticas. Com o desaparecimento do GS (1957), o enorme vazio deixado pelo GS leva os artistas locais a criarem o Grupo de Artes Plásticas de Florianópolis (GAPF), que, desafortunadamente, teve curta existência. Muitos artistas dessa época alcançaram projeção no cenário nacional. 


\section{HUMANAS}

\section{Marques Rebelo em Florianópolis}

O Grupo Sul criou um cine-clube, produziu peças de teatro, editou livros e vivia mergulhado em acaloradas discussões literárias. A década de 1950 foi muito importante, pois é o período de maior atividade do movimento modernista em Santa Catarina, quando surgem novos artistas plásticos e revistas de arte. A efervescência intelectual diminui ou é pulverizada com o encerramento da revista Sul. As lideranças diferenciadas e mutuamente complementares de Aníbal e Salim avivavam o GS, mas o modernismo catarinense ganha ainda mais prestígio com o surgimento de um terceiro personagem, o escritor Marques Rebelo (1907-73).

Através dos amigos comuns e da divulgação da revista Sul, o conhecido escritor fica sabendo dos esforços daqueles jovens catarinenses e se dispõe a organizar uma exposição de arte contemporânea em Florianópolis. Ele entra em contato com Armando Simone Pereira, Secretário de Educação do governador Aderbal Ramos da Silva (1947-51). O apoio das duas autoridades foi fundamental para a realização da primeira mostra de arte moderna em Santa Catarina. Foi o próprio Rebelo quem tomou as iniciativas, pois ele estava realizando exposições de arte em outras cidades e na Argentina e se interessara em realizar algo semelhante em Florianópolis. Após a iniciativa de Rebelo, o secretário Pereira busca apoio de Aníbal para a realização da exposição e, ato contínuo, os rapazes do GS acenam positivamente, com entusiasmo e sem refletirem sobre a complexidade do empreendimento.

A exposição de arte contemporânea foi realizada no pátio interno do Grupo Escolar Dias Velho e suscitou reações variadas nos moradores da pequena Florianópolis. Uns ficaram entusiasmados com os avanços da ilha em direção à modernidade, outros demonstraram espanto e até indignação com o uso do glorioso colégio para exposição daquilo que eles consideravam "arte degenerada". O empreendimento foi mais um "escândalo" produzido pelos modernistas, mas rendeu bons frutos. Influenciado pelo escritor carioca e contando com a ajuda dos rapazes do GS, o governador Aderbal Ramos da Silva resolve criar o Museu de Arte Contemporânea (18 de Março/1949). Atualmente, ele é o Museu de Arte Moderna de Florianópolis (MAMF) e se encontra instalado no Centro Integrado de Cultura Prof. Henrique da Silva Fontes (os depoimentos revelam que Fontes foi um ilustre simpatizante dos modernistas). O seu primeiro diretor foi Sálvio de Oliveira, seguido pelo artista plástico Martinho de Haro. 


\section{Grupo Sul e a Revolução Modernista em Santa Catarina}

\section{A travessia do Atlântico e ocaso do GS}

A criação do MAMF mostra que Santa Catarina estava em sintonia com os acontecimentos nas duas grandes metrópoles, São Paulo e Rio de Janeiro. Com efeito, foi apenas no ano anterior que surgiu o Museu de Arte de São Paulo (MASP), criado por iniciativa do industrial Francisco Ciccilo Matarazzo Sobrinho. Atualmente, ele ocupa um prédio de arquitetura modernista, em forma de caixote e com espantoso vão livre; a planta foi desenhada pelo conhecido arquiteto Oscar Niemeyer. O Museu de Arte Moderna (MAM) do Rio de Janeiro foi criado em 1948.

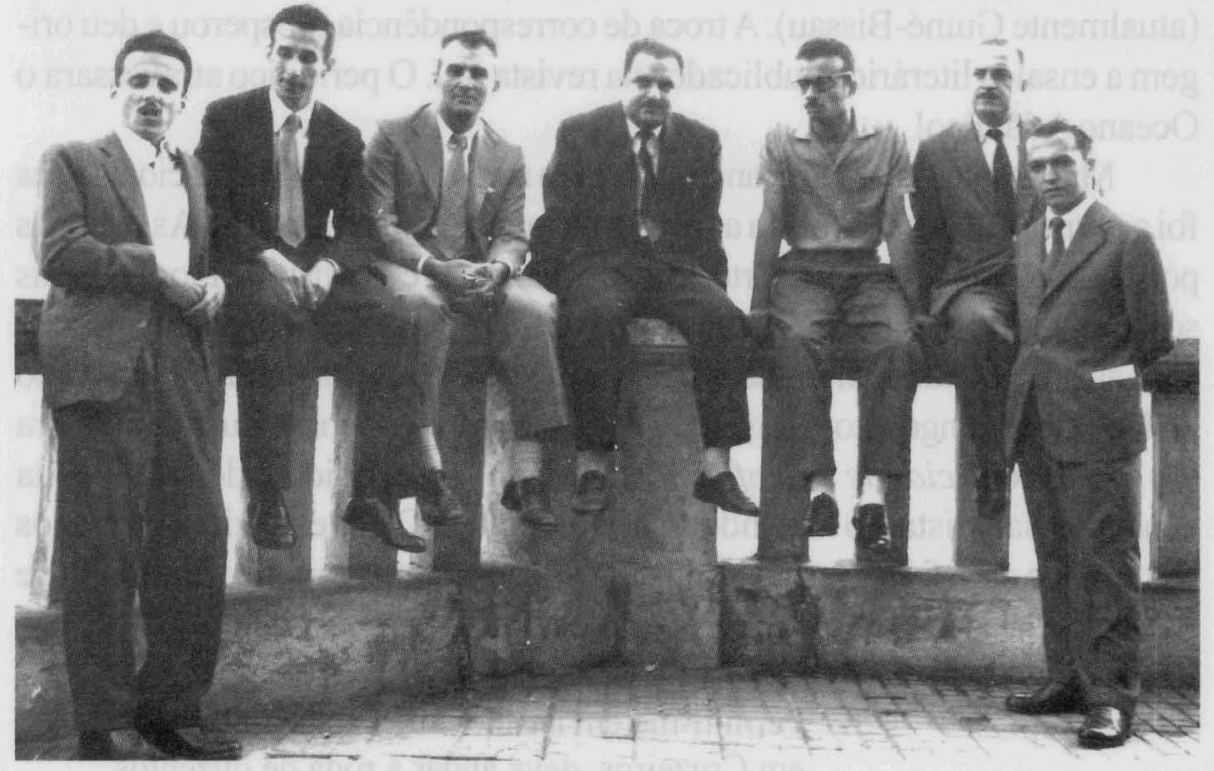

Figura 3

Os modernistas num encontro no Miramar-rebeldes, mas de paletó e gravata. A partir da esquerda: Murilo Pirajá Martins, Armando Carreirão, Elio Ballstaedt, Salim Miguel, E.M. Santos, Aníbal Nunes Pires e João Paulo Silveira de Souza.

O movimento modernista catarinense influenciou as gerações seguintes e teve impacto institucional, como a criação do Museu de Arte Contemporânea. As idéias extravagantes de Marques Rebelo alimentaram os arroubos dos jovens modernistas e interferiram nas relações diplomáticas do Brasil com Portugal e de suas ex-colônias na África. 
O consórcio intelectual entre os modernistas catarinenses com seus pares d'além mar não tem sido examinado como deveria, de modo que nós tentaremos lançar algumas luzes sobre os desdobramentos diplomáticos.

A conversa dos membros do GS com Marques Rebelo foi bastante proveitosa e rendeu sólida amizade. Certa ocasião e numa conversa informal, o escritor sugeriu o intercâmbio com os intelectuais portugueses e africanos. Novamente, a sugestão foi bem recebida e a troca de correspondência se deu inicialmente com o português Manuel Pinto e o moçambicano Augusto dos Santos Abranches, mas logo se instalou um importante canal de comunicação com os intelectuais de Angola, Cabo Verde, Guiné Portuguesa (atualmente Guiné-Bissau). A troca de correspondência prosperou e deu origem a ensaios literários publicados na revista $\mathrm{Sul}$. O periódico atravessara o Oceano Atlântico!

Muitos intelectuais africanos ganharam reconhecimento intemacional, mas foi a revista Sul que lhes abriu as portas no início de suas carreiras. As colônias portuguesas enfrentavama forte censura salazarista e a revista de Florianópolis se tornou um elemento importente para vencer o bloqueio. Salim Miguel relata bem as dificuldades enfrentadas pelos africanos. A revista publicou um conto de José Graça, angolano que ganhou fama intemacional como Luandino Vieira - o seu livro $A$ cidade e a infáncia (1957) foi apreendido e destruído pela censura salazarista, só restando três exemplares. O GS estendera os braços aos irmãos da África e estes viram o gesto como uma rara oportunidade de sobrevivência, como pode ser visto no depoimento de Luandino:

Permiti-me enviar-lhe um cheque cujo valor, em Cruzeiros, deve andar à roda de duzentos e qualquer coisa. É para o meu amigo fazerme o favor de adquirir na Agência Farroupilha os seguintes livros... Para reduzir ao mínimo as possíveis complicações, peço-lhe diligenciar para que os livros não venham como encomenda de livraria em que forem adquiridos, mas sim como encomenda particular, oferta de amigo. Se possível, deverão ser vestidos com capas de outros livros vulgares. $E$, finalmente, os embrulhos, que deverão ser pouco volumosos, convém sejam feitos de papel forte. 
- Claro: se o primeiro livro daquela lista custar todo o dinheiro que lhe mandei, adquira esse e mais nenhum. Os outros, comprá-los-ei oportunamente (In: MIGUEL, 2005; p. 42-3).

\section{A rejeição ao modernismo e a "fogueira das vaidades"}

Os antigos intelectuais reagiram de modo desfavorável em relação ao GS, mas alguns deles externavam simpatias e apoiaram sistematicamente os jovens modernistas. Entre aqueles que hostilizaram, o patrono foi Altino Flores (1892-1984), membro da Academia Catarinense de Letras e jornalista influente. Os simpatizantes foram Henrique da Silva Fontes (1885-1966), Oswaldo Rodrigues Cabral (1903-78) e Othon da Gama Lobo D'Eça (18921965), todos intelectuais respeitáveis. A rejeição ao GS foi resultante da colisão das idéias dos antigos intelectuais e dos modernistas - nos anos $1940 \mathrm{e}$ 50 , Florianópolis era um corpo fossilizado e imperava uma intensa pasmaceira - e pela inclinação ideológica à esquerda de alguns de seus membros, principalmente de Eglê Malheiros e Salim Miguel.

O modernismo esteve associado erroneamente ao anarquismo e ao comunismo, o que explica parcialmente as animosidades que os modernistas enfrentaram nos anos que se seguiram à instalação do regime militar (196485). Com efeito, Aníbal sofreu os efeitos negativos da convivência com os "comunistas" do GS, mesmo sendo professor respeitável e filho de tradicional família catarinense. $O$ grupo era composto por gente de todo o tipo e as discussões giravam em torno das artes. Entretanto, dois membros importantes do GS tinham idéias incompatíveis com o conservadorismo da ilha: Eglê militava no Partido Comunista do Brasil e Salim, seu companheiro durante todos esses anos, compartilhava as mesmas idéias, embora nunca tivesse envolvimento com qualquer partido político.

O casal modernista passou uma temporada nos cárceres da ditadura $\mathrm{e}$ sofreram perseguições políticas; as duas prisões ocorreram logo no início do golpe militar, em Abril/1964 (ver MIGUEL, 1994). Ainda na prisão, Salim soube da destruição da Livraria Anita Garibaldi - ela não mais lhe pertencia, mas todos conheciam o local como a "livraria do Salim". Alguns desafetos atearam fogo da livraria, formando uma enorme fogueira com preciosos livros de arte, fotografia e literatura geral. Livros sobre cubismo foram confundidos com qualquer coisa relacionada a Cuba e serviram para alimentar as chamas da enorme fogueira instalada na rua Felipe Schmidt! 


\section{HUMANAS}

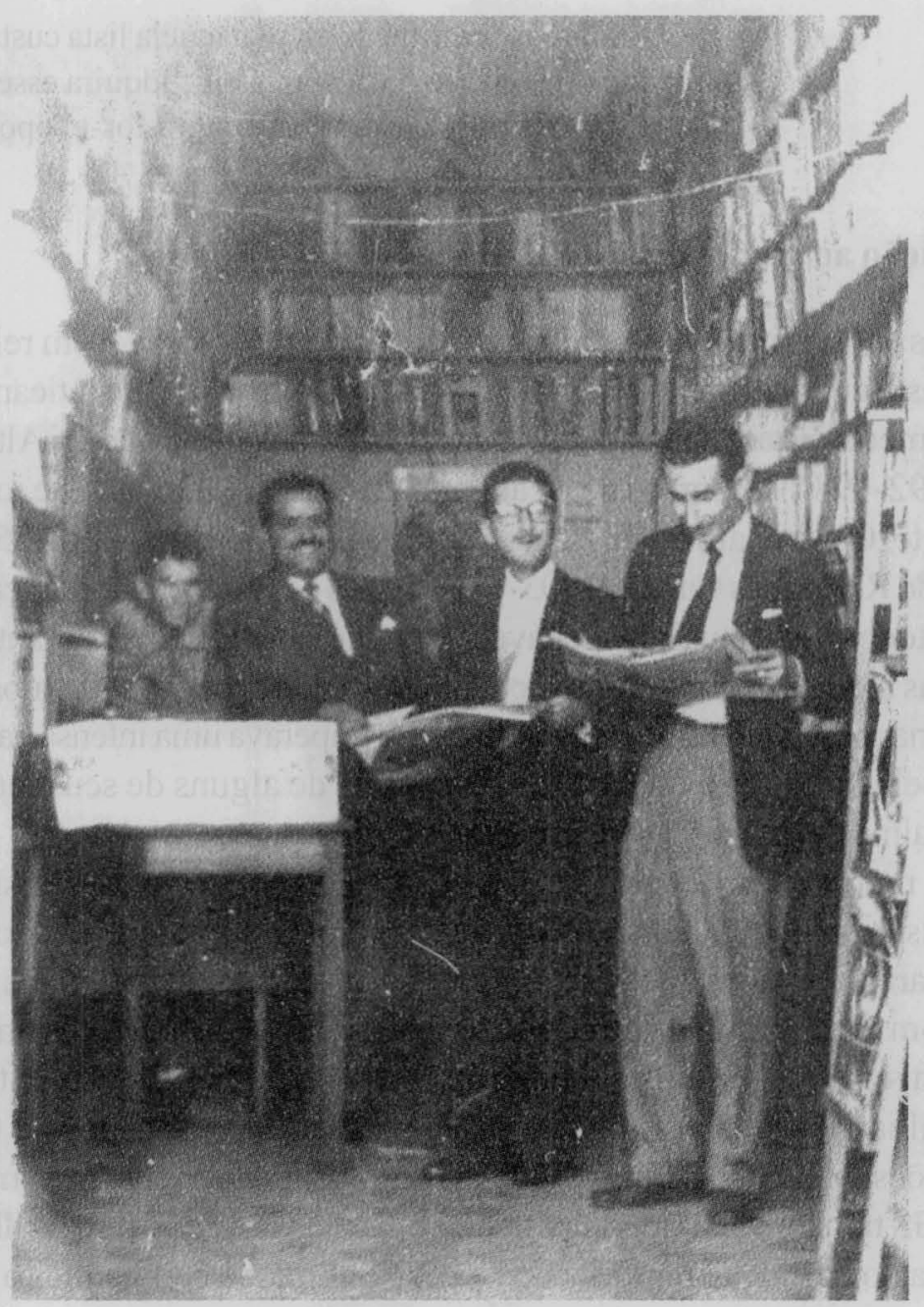

Figura 4

O ambiente da conhecida livraria do Salim. A partir da esquerda: o funcionário que cuidava dos negócios, Salim e seu sorriso generoso, Humberto Aníbal Clímaco e Armando Carreirão.

O incêndio criminoso revela que certos episódios estranhamente se repetem ao longo da história. Com efeito, a destruição dos livros é uma repetição da "fogueira das vaidades", evento que fora conduzido por Girolamo Savonarola (1452-98), padre dominicano que ordenava a queima de objetos considerados frívolos pela Igreja Católica (i.e., pinturas de artistas famosos, 
adornos variados, jogos de cartas e livros catalogados pelo Index Librorum Prohibitorum). Uma imensa fogueira era promovida durante as festas comemorativas do carnaval, para deleite dos fanáticos. Savonarola incitava os fiéis a se despirem de todas as "frivolidades mundanas", mas ele ganhara muitos inimigos, dentro e fora da Igreja Católica. Certa ocasião, ele é convocado a Roma para se defender de acusações de heresia (1495), mas mantém suas opiniões; ele é expulso da Ordem dos Dominicanos e é condenado à morte na fogueira (1498). Alguns vêem Savonarola como um fanático imerso no mundo das trevas, mas outros consideram um santo e mártir do catolicismo. As dúvidas persistem, mas, felizmente, os livros e as idéias sempre sobrevivem a todo tipo de fanatismo.

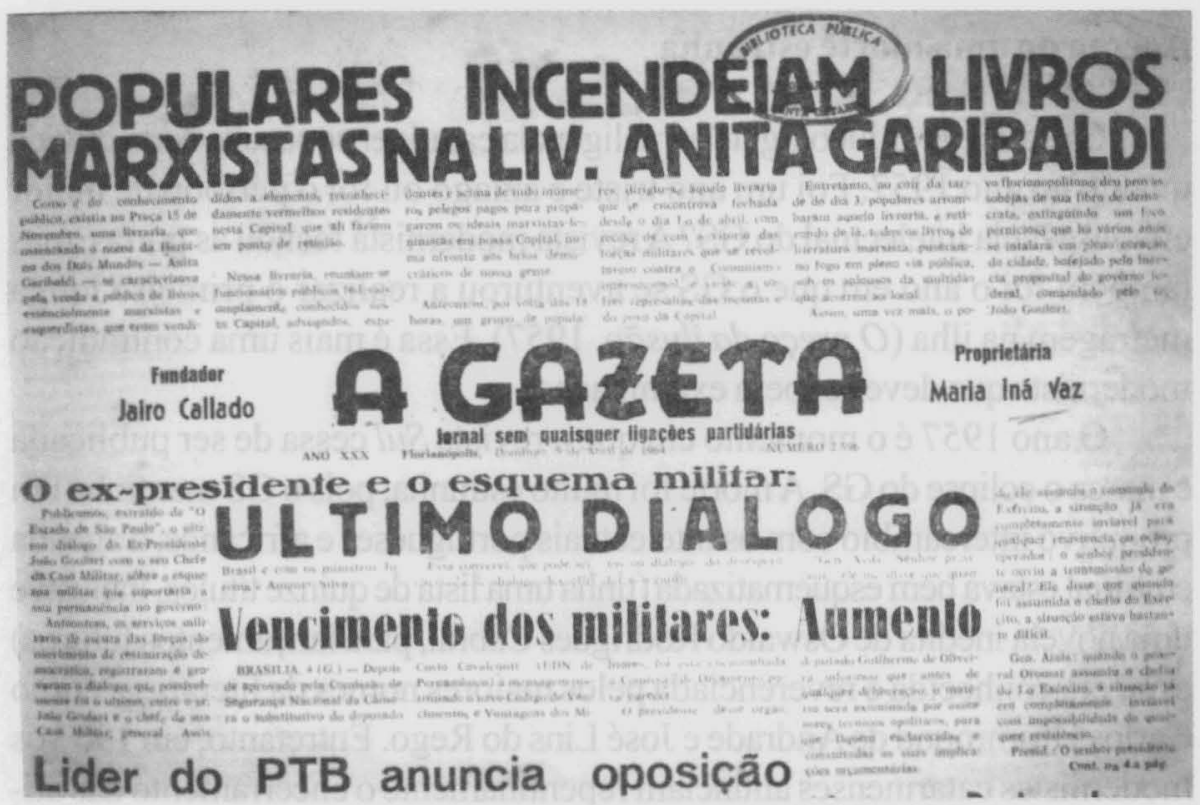

Figura 5

Manchete do jornal A Gazeta noticiando o incêndio da livraria "marxista" do Salim (5 de Abril/1964).

O destino do medonho Savonarola foi o limbo da história, tal como ocorreria com os discípulos retardatários que agiram em Florianópolis. Livros e obras de arte são as mais puras manifestações do gênero humano e devem ser preservados. Os depoimentos de Salim e Eglê apontam os possíveis motivos que levaram à prisão dos dois e à destruição da livraria. 


\section{HUMANAS}

Interessantemente, os dois postulam que tais barbarismos foram prejudiciais aos atores que deles participaram. Com efeito, a sociedade florianopolitana ficou sensibilizada com a prisão de Eglê, pois Salim já se encontrava na prisão e ela foi forçada a deixar os filhos quase que entregues à própria sorte. Por mais que rejeitemos as idéias de alguém, a integridade familiar e a devoção aos filhos sobrepujam qualquer viés ideológico, da mesma forma que livros e obras de arte são símbolos da civilização e devem ser preservados, não destruídos. Florianópolis era uma cidade pacata e provinciana, mas os moradores logo perceberam que os episódios eram exagerados e despropositados. Submeter crianças à privação dos carinhos de uma mãe atenciosa $\mathrm{e}$ a destruição dos livros anunciavam que a barbárie estava do outro lado.

\section{Acerca de uma morte estranha}

O estudo da arqueologia da inteligência catarinense suscita certa dúvida quanto ao ano 1957. Foi um ano triste e aziago ou foi o período de maior efervescência intelectual do GS? A revista modernista fechou as portas, mas também foi o ano em que o GS se aventurou a realizar o primeiro longa metragem na ilha ( $O$ preço da ilusão, 1957). Essa é mais uma contradição modernista que deve ser bem examinada.

O ano 1957 é o momento em que a revista $\mathrm{Sul}$ cessa de ser publicada e marca o eclipse do GS. A morte foi muito estranha, pois o GS mantinha um produtivo intercâmbio com os intelectuais portugueses e africanos, a agenda editorial estava bem esquematizada (tinha uma lista de quinze títulos, inclusive uma novela inédita de Oswaldo Rodrigues Cabral, para lançamentos futuros) e Sul era conhecida e reverenciada pelos maiores nomes da literatura, como Carlos Drummond de Andrade e José Lins do Rego. Entretanto, em 1957 os modernistas catarinenses anunciam repentinamente o encerramento das atividades da revista. O escritor Affonso Romano de Sant'Anna lamenta o episódio no jornal Diário de Minas (16 de Março/1958) e fornece uma explicação para tal:

Dá para cismar porque e até quando o governo terá tanto desleixo para com as coisas de cultura. Sim, porque, a SUL morre por falta da seiva monetária. Morre, porque nesse País ainda é loucura fazer arte e meter-se a literato. Morre (DE SANT'ANNA, 2004; p. 24). 
A explicação do ilustre mineiro não é inteiramente correta, pois as limitações orçamentárias sempre perseguem os programas editoriais e as dificuldades deveriam ser bem maiores no início das atividades do GS. As causas para o encerramento das atividades da revista $S u l$, a locomotiva do trem modernista, deve ser atribuída a um conjunto de fatores. Ainda no número 29 (meados de 1957), a revista exibia seus planos editoriais e listava os futuros lançamentos dos Cadernos Sul e das Edições Sul, mas no número seguinte (Dezembro/ 1957) vem a ducha fria: a partir do número 30 , a revista não mais seria publicada. O otimismo se transforma em desalento total, pois não mais havia entendimento entre os membros do grupo - palavras lacônicas de Salim Miguel informam que o "mofo acadêmico estava se infiltrando nas páginas da revista".

A revista era confeccionada na Imprensa Oficial do Estado de Santa Catarina, o que permitia a manutenção da qualidade gráfica. Em virtude do aumento na demanda dos serviços, o Governo do Estado tentou limitar o uso de suas instalações, mas as novas condições não inviabilizavam o sucesso da revista; a proposta era compatível com a rotina de publicação, mas os editores da revista decidiram pelo encerramento das atividades. Parece que as restrições da Imprensa Oficial foram apenas um pretexto para o encerramento das atividades de Sul. Após uma década de trabalho, as atividades febris trouxeram fama e respeitabilidade aos modernistas de Sul, mas o empreendimento não trazia nenhum retorno financeiro ou qualquer tipo de remuneração aos responsáveis pela revista (SABINO, 1979).

Os integrantes do GS eram alunos secundaristas do Colégio Catarinense quando iniciaram a aventura modernista, mas agora tinham mais de trinta anos, eram casados e lutavam para garantir o sustento de suas famílias. Assim sendo, os interesses conflitavam, a dedicação exclusiva foi minguando gradativamente e a carga de trabalho foi ficando penosa para aqueles que teimavam em manter em funcionamento a revista. Como ninguém é de ferro, logo bateu o cansaço...

Os depoimentos que se seguem oferecem mais detalhes sobre a história do modernismo catarinense e as vicissitudes enfrentadas por aqueles jovens idealistas. O escritor carioca Nelson Rodrigues (1912-80), a fina flor do pensamento cínico e conservador, recomendava aos jovens que desejavam trilhar os caminhos do poeta Rimbaud: "Cresçam! Amadureçam o mais rapidamente possível!' Os modernistas paulistas e catarinenses eram jovens quase imberbes, mas o transbordamento de energia foi canalizado para a realização de um sonho, o que provocou mudanças visíveis no mundo das artes e nos costumes. 
O modernismo foi um movimento bastante abrangente e seus efeitos são visíveis nos dias atuais, das artes plásticas até a moderna arquitetura. Outra lição importante a ser extraída da aventura modernista: ouçamos os jovens!

\section{Momentos do modernismo brasileiro e catarinense}

1913 - Publicação do livro Totem e tabu, do médico austríaco Sigmund Freud. Exposição de quadros do pintor Lasar Segall, em São Paulo e Campinas.

1914 -Deflagração da I Guerra Mundial (1914-18).

1915 - Publicação do livro O pirralho, de Oswald de Andrade.

1917 - Revolução russa (1917-22).

Exposição de quadros da pintora Anita Malfatti, em São Paulo.

Publicação de um artigo de J.B. Monteiro Lobato condenando o modernismo.

1918 - Publicação de Urupês, livro inicial de J.B. Monteiro Lobato. 1920 - Fundação da Academia Catarinense de Letras, em Florianópolis.

Criação da revista Terra, cujo editor é Altino Corsino da Silva Flores. 1922 - Criação da União das Repúblicas Socialistas Soviéticas (URSS).

Fundação do Partido Comunista no Brasil.

Revolta do forte de Copacabana.

Primeira travessia aérea do Atlântico Sul, realizada por aviadores portugueses.

História da colonização portuguesa no Brasil, organizada por Carlos M. Dias.

Publicação do livro Paulicéia desvairada, de Mario de Andrade.

Realização da Semana de Arte Moderna.

Criação da revista literária Klaxon.

1924 - Publicação do Manifesto Pau-Brasil, de Oswald de Andrade.

1925 - Publicação do livro O espírito moderno, de Graça Aranha.

1928 - Criação da Revista de Antropofagia.

Criação da revista $O$ Cruzeiro.

Publicação do Manifesto antropófago, de Oswald de Andrade.

1930 - Implantação da ditadura do Estado Novo, liderada por Getulio Vargas. 1933 - Publicação do livro Casa grande \& senzala, de Gilberto Freyre. 1936 - Publicação do livro Raízes do Brasil, de Sergio Buarque de Hollanda. 1939 - Deflagração da II Guerra Mundial (1939-45).

1945 - Guerra Fria (1945-70), período marcado por animosidades entre EUA e URSS. 
1946 - Criação da Folha da Juventude, com uma página de arte moderna.

1947-Realização de um espetáculo teatral para financiar a revista literária Sul.

1948 - Fundação do Museu de Arte Moderna de São Paulo (MASP).

Criação do Círculo de Arte Moderna (CAM).

Nasce a revista literária $\mathrm{Sul}$.

1949 - Fundação do Museu de Arte de Florianópolis (MASF).

Clube de Cinema do CAM, mais tarde Clube de Cinema de Florianópolis.

Exposição de arte no Grupo Escolar Dias Velho, idealizada por Marques Rebelo.

Cadernos Sul lança o livro Idade 21, de Walmor Cardoso da Silva.

1951 - Edições Sul lança o livro Velhice e outros contos, de Salim Miguel.

1957-Realização do primeiro longa metragem catarinense: $O$ preço da ilusão. A revista Sul encerra as atividades.

Diáspora dos modernistas do Grupo Sul.

1960 - Fundação de Brasília (21 de Abril/1960), conhecida pela arquitetura modernista.

1964 - Implantação do Regime Militar.

Salim Miguel e Eglê Malheiros são presos.

A "livraria do Salim" é incendiada.

\section{Referências bibliográficas}

BOAVENTURA, M.E. A Semana de Arte Moderna e a crítica contemporânea. Cadernos de Pós-Graduação da UNICAMP, 8: 1-12, 2006.

CASTELLI, M.A. A revista Terra: literatura e sociedade catarinenses nos anos 20. Programa de Pós-Graduação Literatura Brasileira. Florianópolis: UFSC, 1982.

CORREA, C.H. A criatividade intelectual: dependência e liberdade. In: S.C. dos Santos, Org. Pp. 111-49. Santa Catarina no século XX. Florianópolis: EdUFSC, Univali e FCC Edições, 1999.

COSTA, C. Contribuição à história das idéias no Brasil. Rio de Janeiro: Editora Civilização Brasileira, 1967.

DA SILVA, W.C. Éramos críticos severos de nós mesmos. In: K. Klock (Org.). Sul-Edição especial. Pp. 6-7. Florianópolis: Imprensa Oficial do Estado de Santa Catarina, 2004. 


\section{HUMANAS}

DEAZEVEDO, F. Brazilian culture. Nova York: The MacMillan Co., 1950.

DE SANT'ANNA, A.R. Era uma vez uma ponte. In: K. Klock(Org.). SulEdição especial. Pp. 24-5. Florianópolis: Imprensa Oficial do Estado de Santa Catarina, 2004.

DE SOUSA, S. Salim, o amigo. In: S. Miguel. Minhas memórias de escritores. Pp. 3-5. Palhoça: Editora Unisul, 2008.

FACCHINETTI, C. Psicanálise modernista no Brasil: um recorte histórico. Physis: Revista de Saúde Coletiva, 13(1): 115-37, 2003.

FERREIRA, M.A.T. Anarquismo, anarquistas e Semana de Arte Moderna: o papel dos intelectuais. Fundação João Pinheiro, 7(1): 108-26, 1992.

GUERRA, R.F. Oswaldo Rodrigues Cabral: notas sobre a trajetória de vida de um intellectual brilhante. Revista de Ciências Humanas, 42(1-2): 9-60, 2008.

JUNKES, L. Aníbal Nunes Pires e o Grupo Sul. Florianópolis: EDUFSC e Editora Lunardelli, 1982.

LOBATO, J.B.M. Paranóia ou mistificação? A propósito da exposição Malfatti. O Estado de São Paulo, 20 de Dezembro/1917.

MIGUEL, S. Primeiro de Abril - Narrativas da cadeia. Rio de Janeiro: José Olympio Editora, 1994.

MIGUEL, S. 2005. Cartas d'África e alguma poesia. Rio de Janeiro: TopBooks, 2005.

MIGUEL, S. Minhas memórias de escritores. Palhoça: Editora Unisul, 2008.

OLIVEIRA, L.L. Repensando a tradição. Ciência Hoje, 7(38): 58-65, 1987.

PINTO, M.I.M.B. Urbes: o modernismo e a paulicéia como ícone da brasilidade. Revista Brasileira de História, 21(42): 435-55, 2001.

SABINO, L.L. O Grupo Sul. Programa de Pós-Graduação Literatura Brasileira. Florianópolis: UFSC, 1979.

SOUZA, R.S.M. Portugal-Brasil: modernismo em perspectiva. Anais do XI Congresso Internacional da ABRALIC: USP, 13 a 17 de Julho/2008. 


\section{Depoimentos}

\section{Salim Miguel}

Ele nasceu em Kfarsouroun, Líbano (30 de Janeiro/1924), filho de uma família de cristãos ortodoxos. Um dos mais destacados escritores de Santa Catarina, Salim foi um dos fundadores do GS, ao lado de Walmor Cardoso da Silva e Eglê, a sua companheira. Ele pertenceu ao corpo editorial da revista Ficção (Rio de Janeiro, 1976-79), foi diretor executivo da Editora da UFSC e presidente da Fundação Cultural Franklin Cascaes. Seus interesses pela sétima arte levaram-no a atuar como co-roteirista de $O$ preço da ilusão, $A$ cartomante e Fogo morto.

Dono de uma vasta obra literária, destacamos os seguintes livros: Velhice e outros contos (1951), Alguma gente (1953), Rede (1955), O primeiro gosto (1973), A morte do tenente e outras mortes (1979), A voz submersa (1984), Dez contos escolhidos (1985), O castelo de Frankenstein, anotações sobre autores e livros (1986), A vida breve de Sezefredo das Neves, poeta (1987), As areias do tempo (1988), O castelo de Frankenstein, II (1990), As várias faces (1994), Primeiro de abril, narrativas da cadeia (1994), As desquitadas de Florianópolis (1995), Onze de Biguaçu mais um (1997), Variações sobre o livro (1997), As confissões prematuras (1998), Nur na escuridão (1999), Apontamentos sobre meu escrever (2000), Eu e as corruiras (2001), Mare Nostrum (2004), As cartas d'África e alguma poesia (2005), O sabor da fome (2007), Minhas memórias dos outros escritores, anotações sobre autores e livros (2008) e Jornada com Rupert (2008).

Salim Miguel é um autodidata e não possui qualquer graduação universitária, mas, em reconhecimento aos seus méritos, a UFSC lhe concedeu o título de Doutor Honoris Causa (13 de Junho/2002). O livro Eu e as corruíras (2001) deu a Salim o cobiçado prêmio Juca Pato de Intelectual do Ano (2002), outorgado pela União Brasileira de Escritores, em parceria com o jornal Folha de São Paulo. Ao finalizar este texto também ficamos sabendo que a Academia Brasileira de Letras o homenageou como prêmio Machado de Assis (2009). Salim teve longa atuação como jornalista, foi dono de livraria e editora e se aposentou como funcionário público. Seus amigos insistiram, sem sucesso, para que ele ingressasse nos quadros da Academia Catarinense de Letras, mas ele sempre alegou incompatibilidade com os ares e as formalidades da academia. 


\section{HUMANAs}

\section{Eglê Malheiros}

Ela nasceu em Tubarão/SC, 3 de Julho de 1928. É professora, escritora, tradutora. Eglê cursou Direito na UFSC e concluiu o Mestrado em Comunicação (Universidade Federal do Rio de Janeiro). Ela foi professora do Instituto Estadual de Educação, onde foi lente de História; teve atuação em todos os momentos do GS, onde publicou o seu primeiro livro de poemas (Manhã, 1952; Edições Sul); mais tarde surgiram outros livros, como Vozes veladas (1996) e Os meus fantasmas (2002). Ela participou dos primórdios do modernismo, desde a publicação do jornalzinho Folha da Juventude até a extinção do GS. Ela pertenceu ao corpo editorial da revista Ficção (Rio de Janeiro, 1976-79) e foi diretora-secretária da Fundação Nacional do Livro Infantil e Juvenil; além dos interesses literários, ela também atuou como co-roteirista de

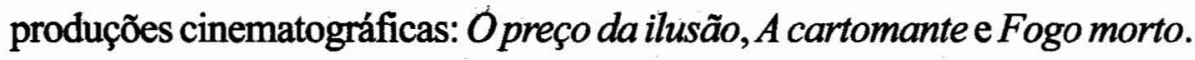
Eglê é funcionária aposentada do serviço público.

\section{Walmor Cardoso da Silva}

Ele nasceu em Florianópolis, 2 de Junho de 1927. Formou-se em Direito e em Filosofia, onde teve como colega Eglê Malheiros, que o convidou a integrar o grupo dos modernistas catarinenses. Ele foi secretário da revista $S u l$, a partir da $13^{\mathrm{a}}$ edição, onde publicou vários poemas - outros poemas também se encontram espalhados nos jornais $O$ Estado e $A$ Gazeta. Walmor também participou de encenações de peças teatrais: Como ele mentia ao marido dela e Cândida, ambas de George Bernard Shaw e dirigidas por Ody Fraga e Silva (1927-87), outro modernista de primeira hora. A sua atuação como Pinocchio na peça homônima é até hoje bastante lembrada pelos amigos e pesquisadores da história do teatro em Santa Catarina. Ele publicou o livro de poemas Idade 21 (Cadernos Sul, 1949) e anunciou que viria outro livro de poemas, promessa que não se concretizou. Os amigos até hoje sentem-se frustrados.

Após a cessação da febre modernista, Walmor acabou se dedicando à advocacia e ao ensino universitário. O livro Idade 21 merece ser destacado por dois motivos: foi o primeiro que germinou nos Cadernos Sul e é nesse ano (2009) que a obra completa 60 anos de vida. Walmor conviveu intensamente com os modernistas catarinenses, foi aluno do desembargador Henrique da Silva Fontes; ao lado de sua esposa, D. Emiliana Simas Cardoso da Silva, 
ele é um dos fundadores do curso de graduação em Psicologia da UFSC, onde ingressou em 10 de Março/1967. Ele é professor aposentado e participa intensamente, junto com D. Emiliana, das atividades do Núcleo da Terceira Idade da UFSC.

RCH - Como foi a sua infância?

Salim-Meu pai saiu do Líbano e pretendia se fixar nos EUA, em busca de melhores condições de vida. Não havia emprego no Líbano e o país pertencia ao império otomano. Posteriormente, Síria e Líbano foram desmembrados e se transformaram em protetorados inglês e francês, respectivamente (1918). A transformação agravou mais ainda as condições de vida e meu pai se viu forçado a migrar para outro país. A intenção inicial era migrar para os EUA, pois minha mãe tinha três irmãos naquele país e um de meus primos, com quem eu mantinha correspondência regular, chegou a ser diretor da Biblioteca do Congresso. Infelizmente, o meu pai teve um problema nos olhos - as casualidades da vida, maktub - e nós tivemos que interromper a viagem em Marselha. Junto com meu pai, estavam meu tio, duas irmãs e minha mãe. O meu pai se lembrou de uma irmã que morava em Magé e para lá rumamos, pensando em retomar mais tarde o projeto de mudança para os EUA. Meu pai acabou gostando do Brasil e aqui instalou um comércio (secos e molhados, como era então conhecido), mas não tinha a mínima vocação para tal. Minha mãe tinha estudado russo e inglês e meu pai, o idioma francês; ambos me entretinham contando as histórias de As mil e uma noites. Aos oito anos de idade, eu descobri um almanaque contendo o poema "A Carolina", de Machado de Assis. Um dos mais belos sonetos. O primeiro romance que eu li, aos nove anos: $O$ tronco do ipê (1871), de José de Alencar.

RCH-Quais foram as primeiras impressões sobre o Brasil? Existia algum tipo de preconceito em relação aos imigrantes?

Salim - As pessoas diziam que no Brasil se colhia dinheiro em árvore, de modo que meu pai se sentiu motivado para mudar para o país. Ele queria dar educação e transmitir ensinamentos éticos aos filhos. Meu pai começou mascateando em Magé, mas logo ele se lembrou de uns primos que moravam em Florianópolis. Em 1928, ele abre uma vendola em São Pedro de Alcantara, o primeiro núcleo de colonização alemã em Santa Catarina, instalado 100 anos atrás. 


\section{HUMANAs}

Eu fui alfabetizado em árabe e alemão. Em seguida, nós rumamos para Biguaçu (1931-43), onde passei uma boa parte de minha infância e me transformei num cidadão de duas naturalidades: líbano-biguaçuense. Houve uma nova mudança da família para Florianópolis, pois a II Guerra Mundial havia tornado a vida difícil para os comerciantes (meu pai vendia muito fiado, não recebia e o negócio não prosperara). Na capital, meu pai abriu outra loja de secos e molhados e, em seguida, passou a vender tecidos. A lojinha foi instalada na rua Padre Miguelinho, ao lado da Catedral Metropolitana.

RCH - Como era o ambiente no Colégio Catarinense?

Salim - Eu freqüentava o curso clássico e era péssimo em matemática. Aníbal Nunes Pires era professor do Colégio Catarinense e ele próprio julgava que clássico e científico deveriam ser separados, pois o primeiro é mais direcionado para o lado das ciências humanas, enquanto que o curso científico era mais voltado para as ciências exatas. Como eu tinha dificuldade em aprender matemática, resolvi interromper os estudos. Com a criação da Faculdade de Filosofia (1954), o Aníbal me estimulou a ingressar no curso de filosofia, pois na época não havia a exigência dos exames vestibulares e, além disso, eu tinha "notório saber"- eu havia publicado alguma coisa e já era conhecido. Para frustração do Aníbal, eu recusei.

RCH - O casal Eglê e Salim formam uma parceria intelectual cuja duração ultrapassa meio século. Como vocês dois se conheceram?

Eglê - Salim me disse que me conheceu numa peça de teatro, mas eu o conheci muito antes disso. Eu tive que me mudar para Porto Alegre para cursar o $2^{\circ}$ grau no Colégio Americano, pois em Florianópolis não havia o curso para moças. Eu tentei cursar no Ginásio Catarinense, pois havia uma lei que dizia que quando não houvesse escola para mulheres, elas poderiam se matricular num colégio de rapazes. Eu fui falar com o padre Braun, do Colégio Catarinense, e ele respondeu: "-A senhora poderá cursar com os rapazes, mas enfrentará muitas dificuldades". Eu acabei optando por realizar meus estudos em Porto Alegre. Nessa ocasião, eu participava das agitações políticas do pós-guerra e sempre retornava a Florianópolis nas férias. A sede do Partido Comunista ficava na Praça XV e foi lá que eu conheci o Salim. Ele não se lembra de mim, mas eu disse para a minha mãe: "Eu conheci um rapaz tão inteligente, mas é uma pena que ele é filho de libaneses, pois logo se casará com uma patrícia!". Isso foi por volta de 1945. 
RCH - Como surgiu a idéia de criação de um grupo literário?

Eglê - Inicialmente, o grupo era composto por Salim, Ody, Paladino, Anibal, Walmor e eu. Mais tarde, outros foram se agregando ao grupo. Ele surgiu na Praça XV, onde os jovens da cidade tomavam sorvetes e bebiam café. Havia muita discussão sobre assuntos variados e tínhamos oportunidade de conhecer poesias produzidas pelos colegas. A idéia de criação da revista Sul emergiu naturalmente. Ela não era registrada, não tinha sede (exceto a caixa postal 384) e nós nos reuníamos na praça ou na casa de algum dos componentes do grupo, a fim de estabelecer os rumos para novas edições. Tudo era informal e improvisado. As duas primeiras edições da revista eram pura balbúrdia e nós utilizamos muito material da embaixada inglesa e francesa para ilustrar a revista. Entretanto, o terceiro número já tem o aspecto definido de uma revista literária, pois a edição foi dedicada ao poeta Cruz e Sousa; mais tarde, ela passou a ser ilustrada por Aldo Nunes, Silveira D'Ávila, Hassis, Meyer Filho, Hugo Mund e outros que se tornaram importantes artistas plásticos.

RCH-Qual era a novidade do movimento modernista? Quais eram os objetivos? Eglê - O movimento demoliu a idéia da "torre de marfim": os poetas se julgavam superiores às demais pessoas, mas nós mostramos que éramos "trabalhadores intelectuais". Este grupo era composto por pessoas cultas (advogados, médicos, engenheiros), mas seus membros não agiam de modo organizado. Cada um ficava encerrado em sua poesia ou em seu conto, como se vivesse num mundo à parte. Nós éramos tratados com certo respeito por alguns, mas nós resolvemos demonstrar que dava para discutir de igual para igual, sem aceitar nada empacotado. Tudo era criticado no Círculo de Arte Moderna, não havia nenhum tipo de hierarquia e o exercício da escrita permitiu um salto de qualidade. Os olhos foram abertos às artes plásticas e cinema, estabelecemos contato com cine-clubes e movimentos literários de outros estados.

RCH-Walmor, descreva para nós como eramos encontros dos "artes modernas". Walmor-Eu já peguei o bonde andando. Eu era colega de Eglê na Faculdade de Direito e fui por ela convidado a participar do GS. Nós começamos em 1947, mas nessa época já existia a Folha da Juventude. Eu escrevia poemas, a cidade era muito pequena e o entrosamento era fácil e agradável. 
Quem liderava o grupo era o Aníbal, que tinha sido o meu professor de matemática e português. Outro professor antigo que simpatizava bastante com o grupo foi Henrique Fontes, que nos chamava de "os artes modernas". O relacionamento dentro do grupo Sul era bastante cordial e nós nos reuníamos no Café Rio Branco, na rua Felipe Schmidt. Dentro do GS havia gente de várias tendências, políticas ou religiosas, mas nós estávamos interessados na literatura e em outras formas de manifestação artística, como o teatro e cinema. Toda a produção literária era feita de modo artesanal, mas as pessoas liam o que escrevíamos. Apóś a publicação de um texto, surgia o Fontes em sala de aula dizendo: "Olha, eu li a página tal. Gostei muito!". Outros que externavam suas simpatias em relação ao grupo foram Othon Gama D'Eça, Madeira Neves e Osmundo Wanderley da Nobrega.

Salim -A designação grupo Sul só surgiu mais tarde, em função da revista Sul, mas o nome original era Círculo de Arte Moderna. Não existia nenhum líder entre nós e as palestras eram organizadas para permitir o debate de temas literários e coisas afins. Ody Fraga era quem mais se envolvia com essas atividades e, com efeito, certa ocasião foi programado que ele daria uma palestra. Ele não compareceu, pois nós ficamos bebericando num bar e acabamos deixando de lado o evento. $O$ professor Fontes, que nunca perdia uma dessas palestras, no dia seguinte protestou em sala de aula: “-Vejam só o que é arte moderna. Marcam palestras, mas nem o próprio palestrante comparece! Mas eu compareci!"

RCH-O movimento catarinense estava em sintonia com os modernistas de São Paulo?

Salim-ASemana de Arte Moderna havia ocorrido em 1922 e o próprio Mario de Andrade, num depoimento no Ministério das Relações Exteriores, já apontava a necessidade de reavaliação. Em Florianópolis, falar sobre arte moderna era quase motivo para ser preso. O poeta Carlos Drummond de Andrade escreveu um poema dizendo haver "uma pedra no meio do caminho" e alguém dizia: "isso é poesia?’ Nós tentamos fazer aqui algo que já estava sendo reavaliado no país. O Círculo de Arte Moderna já incorporava todas essas reavaliações. Nós queríamos mostrar algo novo. Florianópolis estava parada no tempo e existiam apenas quatro jornais ( $O$ Estado, Diário da Manhã, Diário da Tarde e $A$ Gazeta) e uma revista no estado (Atualidades). 
RCH - Houve algum conflito com os intelectuais "conservadores"?

Eglê -Alguns deles aceitavam bem as propostas do GS, outros imaginavam que nós estávamos ocupando o lugar deles e houve forte reação contrária. Os simpatizantes foram Henrique da Silva Fontes, Oswaldo Rodrigues Cabral, Arthur Pereira e Oliveira, Othon Gama D'Eça e Wilmar Dias, pois eram intelectuais respeitáveis e nós tínhamos uma boa convivência. O prof. Cabral chegou a publicar um texto na revista $\mathrm{Sul} \mathrm{e,} \mathrm{certa} \mathrm{ocasião,}$ o Fontes chegou a me dizer: “-D. Eglê, que a senhora não coloque pontos e vírgulas em seus poemas, tudo bem. Mas, arrume alguns pontos e algumas vírgulas para que eu possa ler!". Alguns intelectuais ficavam em "cima do muro", mas outros partiam para ataques frontais, como Altino Flores. Ele hostilizou o GS desde o início e, certa ocasião, me designou como a "pequena grande atriz de comédias".

Salim -Altino nos ofendia com regularidade e usava a sua coluna no jornal $O$ Estado para desferir seus ataques. Ele manteve acesa uma polêmica sobre a importância do modernismo, desferindo ataques que duraram mais ou menos um ano. Ao se referir a mim, ele vociferou: "- Esse turco que quer ser escritor, quer ser jornalista... Devia é ficar esfregando a barriga na venda do pai".

RCH - Afinal, quem pertencia de fato ao GS?

Salim - O grupo era aberto e nós tínhamos muitos amigos que conviviam diariamente e nos auxiliavam de várias formas, embora não tenham dado nenhuma contribuição literária ao movimento. Essas pessoas estavam sempre presentes, mas temos dúvidas em julgar se eles pertenciam ou não ao GS. Por outro lado, nós tínhamos colaboradores de outras regiões que nunca haviam dado as caras. Eles mandavam suas colaborações através do correio, a comissão editorial aprovava ou não a publicação e nós mantínhamos uma intensa correspondência. Nós não conhecíamos essas pessoas, mas podemos dizer que elas "pertenciam" ao GS.

RCH - Como era o relacionamento do GS com os membros da Academia Catarinense de Letras? Eles eram favoráveis às inovações modernistas?

Salim - Eles não eram favoráveis, nem contrários ao GS. AAcademia Catarinense de Letras estava paralisada no tempo e sequer havia completado as cadeiras vagas, diferentemente da competição que ocorre nos dias de hoje. 
Naquela época faltavam escritores para completar seus quadros. Muitos membros do GS não entraram para a academia, exceto Hugo Mund Júnior, Oswaldo Ferreira de Mello e Silveira de Souza, representante da segunda fase do grupo. O próprio Silveira dizia: “-O mal da academia é que dela só saímos mortos. Eu não sei por que entrei e não sei como sair!" O Fernando Sabino dizia algo parecido: "Entramos de pé, saímos deitados!"

RCH-Como surgiu a idéia de realização de uma exposição de arte moderna? Salim - Inicialmente, nós lutamos para ganhar espaço e inauguramos uma página de arte moderna, a Folha da Juventude; ela surgiu em Novembro de 1946 e era dirigida pelo Aníbal. Nós devemos muito ao Aníbal, tanto quanto ao Marques Rebelo e Flávio de Aquino, da equipe de Oscar Niemeyer. Flávio era filho do senador Ivo de Aquino; ele morava no Rio de Janeiro e regularmente lhe mandávamos exemplares da revista Sul. Certa ocasião, Marques Rebelo manifestou o interesse de inserir Florianópolis no roteiro das exposições de arte contemporânea, realizadas no Brasil e exterior. Flávio mandou uma carta ao Aníbal expondo o interesse e, sem medir as conseqüências, o grupo se manifestou prontamente favorável à mostra.

RCH - Qual foi a reação dos moradores de Florianópolis? A exposição de arte moderna foi bem sucedida?

Salim - Ela ocorreu no pátio interno do Grupo Escolar Dias Velho. Muitos moradores ficaram escandalizados com as pinturas e mais ainda com as três palestras do Marques Rebelo. Um pecuarista viu um quadro de Iberê Camargo, retratando um boi, e disse: “- Estou notando vários defeitos nesse boi!". Por outro lado, as palestras do Marques Rebelo apresentavam os novos conceitos de arte, mas o seu estilo irreverente e suas frases "machucavam" alguns ouvintes. Certa ocasião, um jornal do Rio de Janeiro lhe perguntou quais os dez escritores mais importantes do país. Ele respondeu: "Não existem dez, mas apenas dois. Eu e o Graciliano Ramos!'. Marques Rebelo era uma pessoa divertida e sabia orientar os novos talentos. Toda vez que nós nos encontrávamos no Rio, ele chegava com um livro e dizia: "-Olha, eu tenho esse livro aqui. Eu tenho dois exemplares. Você fica com ele, lê e me diz o que você acha". Foi assim que nós tivemos contato com escritores importantes, como Jacobsen e Raymond Radiguet. Certo dia, ele trouxe o livro de Jules Renard e ficou frustrado ao saber que nós já conhecíamos e que havíamos publicado uma tradução de sua peça (Prazer de romper), feita por Hercílio Medeiros. Marques Rebelo não se conteve: "-Como vocês conhecem?!" 


\section{Grupo Sul e a Revolução Modernista em Santa Catarina}

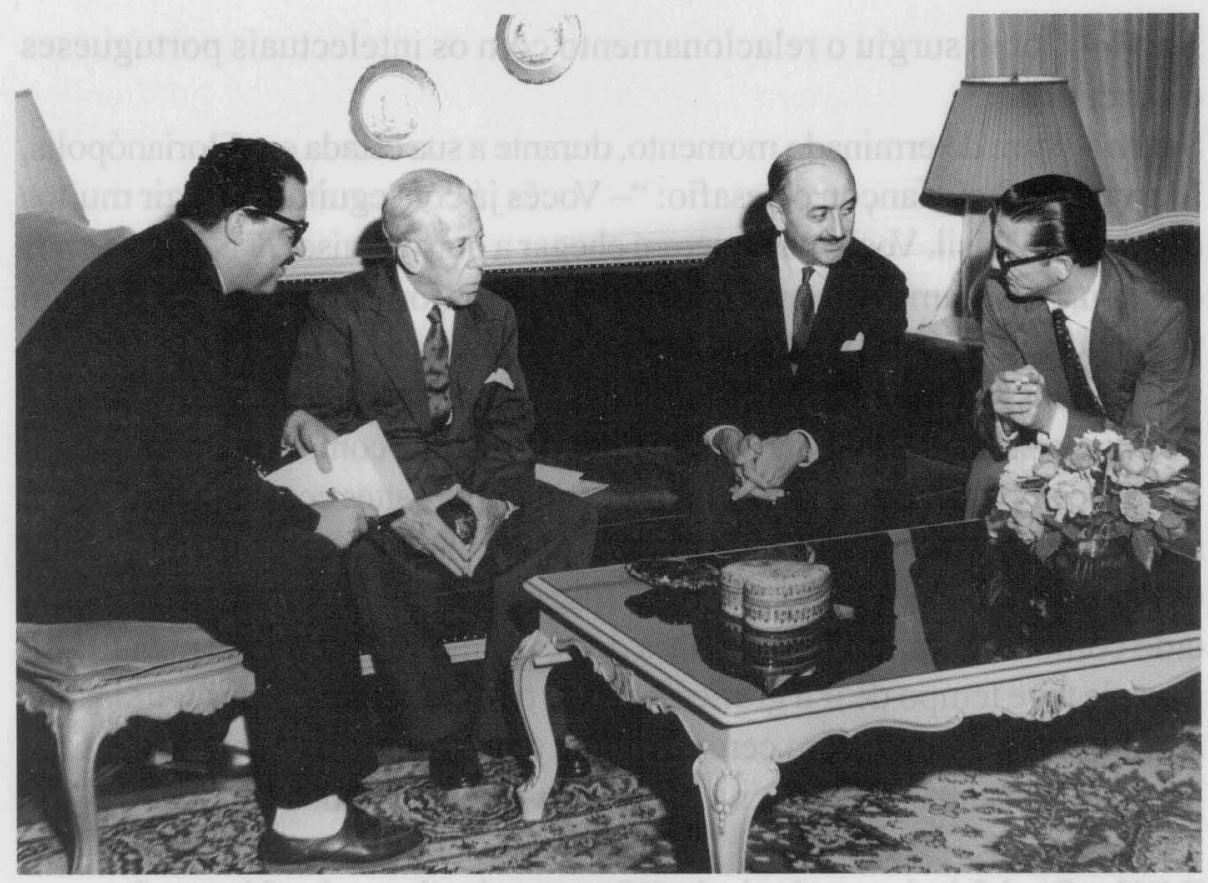

Figura 6

O encontro de Salim Miguel com autoridades no Palácio da Agronômica, residência oficial do Governo Estadual de Santa Catarina (1956). A partir da esquerda: Salim (meias brancas), presidente Herbert Moses (Associação Brasileira de Imprensa) e o governador Jorge Lacerda e seu Assessor de Imprensa, José Hamilton Martinelli.

RCH - O governo estadual apoiou os modernistas catarinenses?

Salim - O governador Aderbal Ramos da Silva e o secretário Armando Pereira deram integral apoio à vinda de Marques Rebelo, o que permitiu a exposição de pintores modernistas, como Di Cavalcanti, Portinari, Pancetti e Iberê Camargo. A exposição contribuiu decisivamente para a criação do Museu de Arte Moderna de Florianópolis (1949). Inicialmente, a nossa revista era confeccionada numa gráfica particular e a composição era manual, mas, a partir do terceiro número, ela passou a ser feita na Imprensa Oficial do Estado. O secretário Pereira colocou a estrutura à nossa disposição, mas exigiu que a impressão fosse realizada fora do expediente normal; o fornecimento de papel e o pagamento das horas extras aos funcionários também deveriam ser custeados por nós. Isso permitiu melhor qualidade gráfica e o sucesso da revista, que durou 10 anos. 
RCH-Como surgiu o relacionamento com os intelectuais portugueses e africanos?

Salim - Num determinado momento, durante a sua estada em Florianópolis, Marques Rebelo lançou o desafio: "- Vocês já conseguiram atingir muitos estados no Brasil. Vocês năọ querem chegar a outros países?" Nós dissemos que sim, pois éramos joven simpulsivos. Elenos forneceu o endereco de um poeta português e de outró ens h fta que morava em Mocambique, embora também fosse portuguets. Foi ajpertir desse momento que nós comecamos a interagir com intelectuais de outras partes do mundo, como Argontina, Angola e Moçambique. Esses intelectuigis deram importantes contribuiçōes para a revista Sul, destacando-se o angolano Antonio Jacinto, ministro da Cultura de Agostinho Neto, Viriato da Cruz e José Graca, que se tornou mais conhecido como Luandino Vieira. Alobra deste último foi queimada pela PIDE, mas ele teve tempo de ir à gráfica é salvar trés exemplars. Emo seguida, nós ampliamos o contato com cerca de vinte paises, entre os quais Argentina, Uruguai, Espanha, Itália, China, Uniåo Soviética e Estados Unidos.

RCH-Qual foi a importância do GS para os intelectuais africanos?

Salim - Eu acho que foi uma válvula de escape. Alguns poderiam indagar por que o contato dos africanos não se deu com a Bahia ou com o Rio de Janeiro? Esses estados estavam mais próximos da África e contavam com elementos mais representativos da cultura negra. Por seu turno, Santa Catarina estava mais distante da África, não se destacava no aspecto cultural e a população negra era relativamente muito pequena. Novamente, voltamos ao elemento casual: se não houvesse a interferência direta do Marques Rebelo e a necessidade dos africanos em dar vazão à produção intelectual, o intercâmbio talvez nunca tivesse existido. É importante ressaltar que, na época, já existiam cerca de 40 publicações, nas quais os jovens intercambiavam contribuições com o Brasil inteiro. No Rio Grande do Sul existiam três revistas (Quixote, Crucial e Horizonte) e os próprios catarinenses já contavam com duas revistas: a Sul e uma outra que era editada em Lages por Guido Wilmar Sassi. Um pouco mais tarde, surgiu a revista Litoral, dos irmãos Apóstolo.

RCH - Descreva melhor os traços de personalidade desses dois personagens, Aníbal e Marques Rebelo. 
Salim - Aníbal Nunes Pires era professor de português e matemática. Por causa da participação no GS ele acabou sendo demitido do Colégio Coração de Jesus, o colégio das moças de Florianópolis - ele não tinha "perfil adequado", alegaram as irmãs de caridade. Aníbal não nos deixou uma obra e, com bastante esforço nosso e de sua esposa, D. Geninha, nós conseguimos lhe fazer uma surpresa: a publicação do livro de poemas Terra fraca. Ele se sentia realizado vendo a produção do grupo, sempre nos estimulando. Muito do sucesso do GS nós devemos ao Aníbal e Marques Rebelo, pessoas bem diferentes. Rebelo fumava desbragadamente, mas era abstêmio.

RCH - Qual é o legado cultural deixado pelo GS?

Walmor-Em primeiro lugar, o movimento representou um enriquecimento pessoal. Os benefícios trazidos para Florianópolis só se manifestaram algum tempo depois. As inovações e atividades empreendidas pelo GS inspiraram a criação de novos grupos, como o Litoral e o grupo independente de Hugo Mund Jr. e de Silveira de Souza. Os modernistas também influenciaram as artes plásticas e o GS impulsionou a produção literária de Santa Catarina.

RCH - Salim, v. enfrentou sérios problemas logo no início da instalação do regime militar. Por favor, descreva a prisão e o incêndio da "livraria do Salim".

Salim - Nessa ocasião, eu era chefe do escritório da Agência Nacional e pertencia à assessoria de imprensa do governador Celso Ramos. No governo de João Goulart, o diretor da Agência Nacional foi Josué Guimarães, que foi um excelente jornalista e se transformou num excelente romancista. Ele decidiu abrir escritórios em todos os estados da federação. $O$ objetivo era permitir o entrosamento entre os estados que recebiam notícias da agência central, que ficava no Rio de Janeiro. Eu havia trabalhado com Josué Guimarães no jornal $A$ Hora, de Porto Alegre. Ele me fez o convite para que assumisse a chefia local, eu aceitei. No dia 2 de Abril/1964, eu estava saindo do Palácio Cruz e Sousa e me dirigindo ao correio para despachar uma mensagem telegráfica. Eu resolvi dar uma parada para tomar um cafezinho no Ponto Chic, ocasião em que notei a aproximação de uma ambulância - naquela época a Felipe Schmidt era uma rua aberta, diferentemente dos dias de hoje, que só permite o movimento de pedestres. $O$ comissário se aproximou e disse: "--Estás preso!". Eu fiquei surpreso e julguei que fosse brincadeira. 


\section{HUMANAS}

Ele disse que era sério e tentou me convencer a acompanhá-lo até o $5^{\circ}$ Distrito Naval. Eu relutei e, então, ele propôs a minha condução para a Escola de Aprendizes de Marinheiros. Eu continuei relutando e a conversa durou mais ou menos $30 \mathrm{~min}$. Ele se afastou para um telefonema e ao voltar disse: “-Preso tu estás, mas serás conduzido para o Quartel da Polícia Militar". Ele queria que eu fosse na ambulância, mas novamente eu recusei a ordem, alegando que não estava doente. Foi autorizado que o deslocamento fosse feito num táxi, escoltado por dois soldados que iriam num outro veículo. Entretanto, os dois soldados pediram para ir comigo, pois alegaram que teriam que tirar do próprio bolso os custos da viagem de táxi. Eu aceitei e, portanto, fomos todos nós num único carro em direção ao quartel da Polícia Militar. Eu fui à frente, os dois soltados atrás segurando seus fuzis.

RCH - Quanto tempo durou temporada na prisão?

Salim - Eu fiquei 48 dias preso e fui solto com a intervenção do escritor Adonias Filho, o novo diretor da Agência Nacional. O quartel ficava na Praça Getúlio Vargas, onde no alojamento havia cerca de 60 presos. Parece que os militares não gostavam da palavra "preso", pois diziam que nós estávamos "detidos para averiguação". Outros presos estavam espalhados em outras repartições militares, como a Escola de Aprendizes de Marinheiros e $5^{\circ}$ Distrito Naval; eles eram políticos, operários, médicos e gente de todas as categorias. Eu me lembro de um preso de São Joaquim que ficou 18 dias encarcerado; sempre que um oficial aparecia para verificar as condições do alojamento, ele desatava a chorar, agarrava-se ao oficial e dizia que a sua prisão fora um equívoco. Chorando, ele clamava: “- Por favor, eu não sei o que é agitação! Eu sou apenas um agiota!". Naqueles tempos, um simples telefonema ou uma carta anônima podia conduzir o acusado à prisão.

RCH - Quais foram os motivos que o conduziram à prisão?

Salim -Eu nunca pertenci a algum partido político, embora sempre fosse de esquerda. Eu era sócio numa livraria e fui acusado de vender livros comunistas. Minha livraria vendia de tudo: livros estrangeiros e de arte, mas fui acusado de ser proprietário de uma "livraria marxista". Quando fui preso a livraria não mais me pertencia. Ela foi invadida, depredada e os livros foram queimados em praça pública. O episódio foi noticiado no jornal $A$ Gaze$t a$, mas nenhum outro jornal publicou alguma notícia sobre o vandalismo. 
Eu tenho a impressão que um dos líderes que promoveu a queima da livraria fora o próprio autor da matéria jornalística. Os líderes do grupo ficavam incitando a população a tocar fogo nos livros e a turba era composta por mais ou menos 15 pessoas, entre os quais os três líderes: um comissário da polícia, um empregado de casa de comércio, que tinha ligação com um informante da polícia, e o cabeça da agitação. Teve um quarto líder, que ficava anunciando a queima da livraria numa emissora de rádio, ao mesmo tempo que incitava os populares a irem lá para auxiliar a tocar fogo.

RCH - ...E quanto à sua prisão, Eglê, como ela ocorreu?

Eglê-Eu estava no Instituto Estadual de Educação quando o diretor Pedro Bosco interrompeu a minha aula para informar: "-Olha, Eglê, você tem que ir para casa. Eu recebi ordens para que v. não mais pusesse os pés aqui”. Em solidariedade, ele anunciou que iria entregar o cargo, mas eu pedi para que não fizesse isso. "De que adiantaria você abandonar o cargo? Eles iriam colocar uma pessoa que não tem o seu caráter, o que seria pior ainda", eu lhe disse. Eu fui para casa e me preocupei com as pessoas que não sabiam o que fazer naqueles tempos confusos. Alguns conhecidos foram presos, como o então proprietário da Livraria Anita Garibaldi, que deixou filhos praticamente sozinhos e desamparados. Eu fui à casa de sua esposa e lhe prestei alguma ajuda, sem saber que o pessoal da polícia vinha me seguindo havia algum tempo. Em 6 de Abril/1964, a polícia bateu na minha porta, dizendo que eu estava sendo convocada para prestar depoimento. O Salim já estava preso e eu disse: “-E as crianças?". A minha vizinha ficou com meus filhos e eu acabei indo para o Hospital da Polícia Militar, onde fiquei presa numa das enfermarias. Em seguida, eu fui convocada para prestar depoimento e eles me apresentaram uma lista de pessoas, gente que eu não conhecia e que eles alegaram que eu tinha algum relacionamento. À noite, uma enfermeira dormia comigo no quarto, acompanhada de seu filho de mais ou menos nove anos de idade. A situação era engraçada, pois mãe e filho dormiam tranqüilamente e a chave do quarto ficava bem visível, próxima à cabeceira. Eu nunca pensei em fugir, pois isso deixaria a pobre mulher em sérias dificuldades, mas a facilidade era bastante convidativa.

RCH - Como a sociedade reagiu diante desses atos? Os amigos vieram em socorro? 
Eglê - Muitos cidadãos protestaram pela minha prisão, pessoas que eu nunca soube quem eram - teve até uma senhora que se dispôs a adotar nossos filhos! Eles pediam para que permanecesse em casa, cuidando de meus filhos. Depois do depoimento no Inquérito Policial Militar, eu fui para a prisão domiciliar, o que significou a minha libertação. Minhas crianças ficaram chocadas e pediam, quando iam para a escola, que eu não saísse até o portão, temendo que eu voltasse para prisão. Após a libertação do Salim, eu ainda estava em prisão domiciliar. Quando fui convocada a prestar novo depoimento, eu fiz a minha própria defesa. O presidente da comissão de inquérito era nosso amigo e alegou que eu deveria receber alguma punição, ficando em disponibilidade. Eu não fui demitida do Instituto de Educação, mas não havia nenhuma possibilidade de progresso na carreira. Naquela época, nós estávamos reivindicando horários para estudo e um plano de carreira para o magistério. Havia uma excelente equipe de professores no Instituto de Educação e o próprio governador Celso Ramos apoiava as nossas reivindicações. O golpe militar de 1964 acabou interrompendo tudo isso. Eu sempre tive militância política e todos os alunos sabiam quais eram as minhas inclinações ideológicas, mas nunca houve alguma queixa sobre a minha conduta na escola. É importante ressaltar que eu e Salim fomos tratados com alguma consideração, pois nós ocupávamos cargos importantes e éramos conhecidos na cidade. Os cidadãos comuns não recebiam nenhuma consideração por parte do aparato policial; eles entravam nas residências arrebentando as portas e espancando as pessoas. Eles prendiam quem bem entendessem, sem maiores problemas.

Salim - Eu tenho a impressão de que a sociedade florianopolitana ficou escandalizada e reagiu em nosso favor devido à prisão de Eglê e o incêndio criminoso da Livraria Anita Garibaldi. Os dois episódios dividiram a cidade: como seria possível a prisão de uma mãe, a qual fora obrigada a abandonar os filhos à própria sorte? A destruição da livraria também chamou a atenção dos moradores, pois os livros são símbolos da cultura e do conhecimento; eles são itens valiosos e devem ser preservados, não queimados por uma turba de radicais. Algumas pessoas me apoiaram, tal como o Othon Gama D'Eça que fazia questão de tomar cafezinho comigo, mas, por outro lado, alguns colegas de escola se desviavam do caminho para evitar alguma aproximação. Tais episódios permitiram que eu conhecesse melhor o bicho homem. 
RCH - Maktub é uma palavra do idioma árabe que diz respeito ao papel do acaso em nossas vidas. Descreva as casualidades que nortearam o sucesso do GS.

Salim-São as casualidades e muitos "ses" que explicam a sobrevivência e o sucesso do GS. É possível que o grupo tivesse sucumbido logo no início, caso o Flávio deAquino não fosse amigo do Aníbal e tivessem estudados juntos no Rio de Janeiro. Flávio era amigo de Marques Rebelo e é possível que o GS não tivesse todo o sucesso, caso o próprio Rebelo não estivesse envolvido na mostra de arte moderna pelo país afora ou não externasse ao Flávio o desejo de realizar algo parecido em nosso estado. Armando Simone Pereira, secretário de estado no governo de Aderbal Ramos da Silva, fica sabendo dessas tramitações e, através do Aníbal, pede o apoio do GS para a realização da mostra. Nós éramos jovens e nada sabíamos da complexidade inerente a tal evento, mas manifestamos imediatamente o nosso apoio. Caso não houvesse uma conjugação de esforços, dificilmente a mostra teria sido realizada. Marques Rebelo proferiu três palestras em Florianópolis e isso fez germinara idéia da criação do Museu de Arte Moderna em nosso estado. Em 1949, o governador Aderbal Ramos da Silva designou Sálvio de Oliveira, o primeiro diretor, que se fez seguir por Martinho de Haro. O museu foi inaugurado com somente 6 quadros, mas logo o acervo foi substancialmente ampliado com doações de quadros de pintores modernistas, solicitadas por Rebelo ao governador de São Paulo. Rebelo gostou muito da cidade e sempre manifestava interesse em saber como andava o museu que ele tanto ajudara a criar.

RCH - Descreva o processo de criação literária. O que determina o sucesso literário?

Salim - Escrever é escrever, reescrever e cortar. Algumas vezes, o final vem antes do começo ou o início é um caos, sem que o autor saiba se aquilo terá algum valor ou se o destino será a cesta de lixo. É a arte do imponderável. Eu tenho 30 livros publicados, mas eu ficaria bastante satisfeito, caso eu seja lembrado por apenas um deles. Escritores como Tomasi di Lampedusa (18961957), J.D. Salinger (1919-) e Augusto dos Anjos (1884-1914) publicaram pouco ou apenas uma obra, mas hoje eles são importantes referências literárias. Outros escritores publicaram muito, mas caíram no esquecimento. Eu venho notando o aumento das publicações, mas uma diminuição no número de leitores; o fenômeno pode ser explicado em razão da variedade de entretenimento, principalmente a TV. 


\section{HÜMANAS}

RCH - Uma pergunta de natureza intimista e dirigida ao Salim. Como v. convive com a perda da visão? O prazer da leitura pode ser preservado nessa circunstância?

Salim - Eu sempre fui um leitor voraz e me habituei a nunca abandonar um livro pela metade, mesmo sendo ruim! É claro que a perda da visão provocou uma diminuição em minhas leituras, mas felizmente eu tenho a Eglêe meu neto que lêem em voz alta para mim. Eglê e eu temos interesses comuns e ela tem me auxiliado muito. Na minha idade, as pessoas mais relêem do que lêem novidades; ao reler um romance, eu frequentemente me deparo com certas passagens e fico surpreso: "-Puxa, como deixei escapar isso!". Algumas obras de Machado de Assis eu reli várias vezes, mas ao ouvir uma passagem do texto eu tenho outras informações, as quais me escaparam durante a primeira leitura. Eglê e o meu neto dão a entonação necessária ao texto $\mathrm{e}$ isso facilita ainda mais a apreciação da obra.

\section{Adolfo Boos Jr.}

Ele nasceu em Florianópolis/SC, 16 de Março de 1931. Durante muitos anos foi funcionário graduado do Banco do Brasil, até a aposentadoria - ele sempre se dedicou à literatura, mas mergulhou intensamente na atividade quando encerrou as atividades no BB. As atividades literárias foram iniciadas no GS (1947-57), onde publicou o seu primeiro livro (Teodora \& Cia., 1956); o segundo livro veio bem mais tarde (As familias, 1980), mas o sucesso the garantiu o primeiro lugar no Concurso Virgílio Várzea, da Fundação Catarinense de Cultura. Em 1986, ele participou da $3^{\text {a } B i e n a l ~ N e s t l e ́ ~ d e ~ L i t e r a t u r a ; ~ a ~}$ coletânea de contos Companheira noturna foi classificada em $2^{\circ}$ lugarna categoria contos, e seu romance Quadrilátero, $\mathrm{em} 3^{\circ}$ lugar na categoria romance. Outras obras importantes da carreira de Boos foram Oúltimo e outros dias (1988), Um largo, sete memórias (1998), Presenças de Pedro Cirilo (2001) e Burabas (2005). Ele também participou das coletâneas Contistas novos de Santa Catarina (Edições Sul), Vinte e um dedos de prosa (Ediç̃̃es Cambirela), Assim escrevem os catarinenses (Editora Alfa-Omega) e Este mar Catarina e Este humor Catarina (Editora da UFSC).

RCH-Como foi a sua infầncia? As coisas que mais lhe marcaram? Boos - A minha avó foi a primeira a vender mudas de plantas. A nossa casa era cheia de sombras e meu pai era vendedor de caramelos. 
O quintal era um imenso latifúndio, pois tinha coqueiros e goiabeiras. $\mathrm{Na}$ minha infância, eu lia muito as histórias de Flash Gordon, Tom Mix, Fantasma e Tarzan. Eu me lembro que sentia muito medo quando ouvia o navio do Hoepcke, o qual tocava a sirena quando entrava na Baía Norte, próximo à Ilha Ratones. Meu pai era o chaveiro e era designado a abrir o escritório da empresa; ele saía correndo quando o navio adentrava a Baía Norte e eu corria para dentro de casa cheio de medo. Eu não sei bem a razão do medo, mas certa ocasião apareceu alguém na janela de casa, no meio da noite e no exato momento em que a sirena anunciava a entrada do navio. Eu acho que isso também explica um pouco a gagueira na infância. $O$ distúrbio causava enorme aflição na família, pois era inadmissivel ter um filho homem gago. Era uma tragédia. Quando eu começava a gaguejar, o meu pai dizia: "- Pare, respire fundo, diz e repita". Quando eu ingressei no Grupo Escolar Lauro Muller, a minha tia era professora e recomendava: “-Escreva tudo, não leia". Eu venci o problema e hoje falo pelos cotovelos. O problema da fala me distanciou dos colegas na escola, pois não queria ser motivo de chacotas, $\mathrm{e}$ acabei me transformando num bom aluno. Eu lia muito, principalmente os gibis que estavam entrando no Brasil. Meu avô comprava os gibis para o meu tio Arthur, que morreu em razão do alcoolismo. Ele era quatro anos mais velho e me repassava todas as revistas que havia lido; eu fui alfabetizado aos seis anos de idade e lia tudo que caía em minhas mãos. Num determinado momento, eu comecei a criar minhas próprias histórias.

RCH -Algumas de suas obras descrevem o dia-a-dia dos imigrantes alemães. A sua família sofreu problemas parecidos?

Boos - O meu avô me relatou que durante a II Guerra Mundial houve um quebra-quebra na rua Bocaiúva, onde moravam muitas famílias de origem alemã. O quebra-quebra ocorreu em 1943, quando o Brasil decretou guerra contra a Alemanha. Os populares quebraram tudo o que viram pela frente. $O$ consulado alemão ficava na rua Trompowski e também foi apedrejado pelos manifestantes. A casa de meu pai foi poupada, pois ele era goleiro do Avaí e um dos manifestantes anunciou: "-Aqui, não! Aqui mora o galego Boos". Nós estávamos trancados dentro de casa e eu tive oportunidade de ouvir a frase. Meu avô havia pressentido que ocorreria o quebra-quebra, pois em 1914 havia ocorrido algo parecido no local onde moravam as famílias Molenda e Wendhausen. Advertido por meu avô, o meu pai queimou todas as revistas alemãs que o Hoepcke lhe emprestava, engraxou bem todas as armas e as enterrou dentro de latas de banha. 


\section{HUMANAS}

RCH -...E de onde surgiu a vocação literária?

Boos - Eu sempre fui um bom leitor, marcado por leituras como as de Graciliano Ramos, que exibe um estilo integrado à natureza. Outro autor que me marcou muito foi William Faulkner, o qual evito reler com medo de ser "contaminado" por seu estilo. Érico Veríssimo e o estilo debochado de Marques Rebelo também me agradam muito. Na minha família, o meu avô incentivava muito as mulheres ao estudo, enquanto que aos homens bastava aprender um oficio. Oúnico filho que resolveu estudar foi meu tio Arthur; ele se formou em Direito e trabalhava no IBGE, mas morreu em função da bebida. A sua morte foi um verdadeiro desperdício. Por outro lado, o meu pai nunca quis estudar, mas exigia que as filhas estudassem, para terem um bom casamento.

RCH - Como era o relacionamento com Aníbal Nunes Pires e os intelectuais da época?

Boos - Aníbal Nunes Pires era o nosso pai, quem incentivava a todos. Ele não era companheiro, mas o patriarca do grupo; ele nunca tomava cerveja e se contentava com café. Ele era professor de matemática e, curiosamente, utilizava a própria mesa do bar para escrever as liçðes ministradas aos alunos retardatários. Num determinado momento, ele interrompia a lição, pedia nova xícara de café e solicitava ao garçom que apagasse as fórmulas matemáticas escritas sobre a mesa; ela era feita de um material parecido com fórmica e permitia os rabiscos em sua superfície. Ele dava muitas aulas de reforço por dois ou três cafés; quando a coisa apertava, ele dizia: "-Maneca, traga mais café e passe o pano!" O Aníbal foi bem aceito pela rapaziada, pois ele não usava a sua autoridade para se impor e a sua presença dava certa proteção e facilitava a aceitação do GS. Ele estimulava a produção literária e elogiava até as drogas que nós produzíamos no início da carreira. Para falar a verdade, o Aníbal foi uma espécie de "freio" que manteve o equilíbrio nas ações do GS. A rapaziada tinha espírito desbravador, queria romper as barreiras e a presença do Aníbal estabelecia certa ponderação.

RCH - Descreva o seu relacionamento com os amigos da velha guarda. Boos - Um grande amigo foi o Hassis, artista plástico que eu encontrava durante as minhas caminhadas, após o retorno da Bahia. De vez em quando ele me ligava: "-Venha tomar uma cerveja em meu estúdio". Eu aceitava o convite e ficava contemplando os seus quadros, o que chamava a sua atenção. 
“Estás gostando?", perguntava ele. Ao acenar positivamente, ele me vendia o quadro a preço quase simbólico (mais ou menos 50 reais, nos dias de hoje). Foi assim que adquiri todas as obras do Hassis que compõem a minha coleção: bebia cerveja de graça e ainda levava quadros por 50 reais. Eu fícava sem graça, mas ele insistia. Salim Miguel é outra amizade de valor inestimável. Às vezes, ele até era antipático e não fazia questão de esconder o que pensava, mas sempre foi correto. Eu sempre respeitei a sua opinião. Ao retornar à Florianópolis, após um longo período no Rio de Janeiro, nós nos cumprimentamos e ele agiu como se nós tivéssemos nos despedido no dia anterior. Ele me cumprimentou de modo frio e não houve nenhum abraço. Eu estranhei o seu modo, mas no dia seguinte a amizade já estava engrenada!

RCH - Muitos intelectuais enfrentaram sérios problemas após a instalação do regime militar de 1964. Descreva suas impressões sobre esse período.

Boos-O movimento militar de 1964 castrou a criação artística. Eu trabalhava como fiscal da carteira agrícola do Banco do Brasil e fui convocado para prestar depoimento, pois andava muito pelo interior de Santa Catarina e alguém havia me denunciado, dizendo que eu estava distribuindo panfletos ou talvez até armas. Eu fui convocado à Blumenau, onde prestei depoimento no batalhão do Exército. O comissário me perguntou o que eu estava escrevendo e eu respondi que havia publicado o livro Teodora \& Cia. (1956). "Era subversivo?", perguntou o comissário. "Depende de quem lê", eu respondi. Quem lê a Bíblia e chega à parte que descreve o sexo que Lot fizera com suas duas filhas é capaz de concluir que o livro aborda putaria e coisas do gênero. Em seguida, eu dei detalhes sobre o teor de meu livro e tive a impressão de que o comissário se deu por satisfeito, pois ao final ele disse que eu fora convocado em razão de uma denúncia anônima. Em seguida, eu fui liberado e informado de que deveria aguardar nova convocação para outro depoimento. Eu voltei para Brusque e, junto com minha esposa, fui tomar café num bar, ocasião em que encontrei meu amigo Manfredo Hoffman. Ele não saía do bar e, ao me ver, manifestou espanto: “-Você aqui? O Leleco (o apelido do comissário que ele conhecia) me disse que se tratava de uma denúncia anônima e que iria convocar para prestar depoimento a pessoa que me denunciara". Dentro desse cenário, logo surgiu uma vaga para trabalhar na carteira agrícola do BB na Bahia e eu me candidatei para a vaga de sub-gerência. Meu gerente de Brusque me advertiu: "-Olha, que você ganha, hein!" Era um horror e não havia mais candidatos, de modo que ganhei a vaga. 
RCH-Como foi a mudança para a Bahia?

Boos - Eu ganhei a sub-gerência da Bahia e, então, eu me transferi para Canavieiras, Caitité e em seguida Paulo Afonso. Eu também fui criador de cães para exposição do Kennel Club (Dobermann) e posso dizer que fui "soldado da fortuna", mas depois eu abandonei todas essas atividades. $\mathrm{O}$ interior da Bahia é outra civilização. Eu fiquei encantado com os costumes e o novo cenário. $\mathrm{O}$ sincretismo religioso era uma novidade para mim e ampliou minhas experiências de vida. Minha família detestou e, depois de alguns anos, eu retornei à Florianópolis com armas e bagagens. Durante o período na Bahia, eu perdi um pouco o contato com o GS, pois Salim Miguel, o meu mentor literário, havia se transferido para o Rio de Janeiro.

RCH - Parece que o trabalho no Banco do Brasil foi a causa da interrupção da produção de obras mais extensas, como os romances. É correta essa avaliação? Boos - Naqueles tempos, eu tinha uma pastinha com alguns textos inéditos, mas eu tinha parado de escrever ficção. Eu tinha feito um pouco de jornalismo, mas tinha parado com a produção de textos literários. $\mathrm{O}$ trabalho no BB era extenuante e eu atuava na carteira de crédito, direcionado para a produção cacaueira. Eu permaneci no posto quase dez anos (196675) e tive que retornar à Florianópolis, pois meus filhos estavam crescendo e estavam se encaminhando para a universidade e eu estava envelhecendo. Eu tinha contribuído com GS desde a publicação de meu primeiro livro (Teodora \& Cia., 1956) e, ao retornar à Florianópolis, eu logo me integrei com os antigos componentes do grupo. A minha pastinha estava cheia de textos inéditos e eu tinha que dar um novo direcionamento à minha vida. Eu passei a me dedicar mais intensamente à literatura, o que culminou na premiação na Bienal da Nestlé ( $2^{\circ} \mathrm{e} 3^{\circ}$ lugar, nas categorias Romance e Contos).

RCH-Como foi o início do relacionamento com os intelectuais do GS? Boos - Numa noite de carraspana, eu estava acompanhado por dois amigos (Paulo Santos e Marcos Farias, diretor de cinema) e encontrei o Silveira de Souza e Hugo Mund Jr. num bar. Repentinamente, Silveirinha sobe na mesa e começa a declamar o poema Sete faces, de Carlos Drummond de Andrade. Eu nem sequer sabia quem era Drummond, para você ter uma idéia de como eu era "casca grossa"! Eu fiquei encantado com a recitação e, por assim dizer, o poema facilitou o contato com o GS. Durante a conversa com Hugo Mund, meu primo, eu relatei que tinha algumas coisas escritas, inéditas. 
Ele mostrou interesse e pediu para dar uma olhadinha no conto Fim. Eu atendi ao pedido e, algum tempo depois, eu lhe perguntei a sua opinião sobre o conto. Hugo me informou que passara o conto às mãos de Salim Miguel, o que deixou a minha família escandalizada - além do futuro incerto da literatura, meus parentes julgavam que eu estava me misturando com "comunistas". Florianópolis era uma ilha atrasada e a minha tia, professora, dizia que tudo aquilo era "coisa de maluco". Meu pai também não estimulava a minha carreira literária: ao me ver escrevendo algo, já adulto, ele perguntava: "-O que você está fazendo?" Eu dizia que estava escrevendo um conto e ele devolvia: “-Larga isso! Isso não dá camisa a ninguém!" Quem me estimulou a dar prosseguimento na carreira literária foi Salim; ele lia meus textos, criticava e pedia para ler outras coisas minhas. Ele disse que meus textos eram bons, mas eu tinha que "trabalhar os textos". Eu nunca tinha ouvido falar em coisa parecida, mas logo deduzi que era escrever e reescrever o texto, o que me transformou no escravo do texto.

RCH-Quais foram suas impressões sobre os novos amigos?

Boos-Eu conheci casualmente o Salim. Eu trabalhava numa casa de ferragem no centro de Florianópolis e sempre dava uma passadinha no Café Rio Branco; bem próximo ao local, Salim e Carreirão tinham uma banca de revista. Ele havia lido o meu conto Fim e, através de Hugo Mund, informara que desejava me conhecer pessoalmente. Feito o contato, logo surgiu uma longa e intensa amizade. A banca de revista é transformada numa livraria e, nas minhas horas de folga, eu quase quebrava o pescoço de tanto ler as lombadas dos livros. Walmor Cardoso da Silva também freqüentava muito a livraria. Salim era de esquerda e nunca teve pretensões políticas; era um bonachão. AEglê, sim, era batalhadora e tinha militância política.

RCH - ... E os intelectuais que não pertenciam formalmente ao GS?

Boos - Outro intelectual que contribuiu bastante para o sucesso do GS foi Marques Rebelo, o proponente da exposição de arte moderna e que contou com o suporte dos modernistas catarinenses. O governador Jorge Lacerda também aceitou plenamente as atividades dos modernistas. Após a publicação de meu livro Teodora \& Cia., eu fui encaminhado por Salim ao governador, ocasião em que nós dois despendemos um bom tempo conversando.

RCH - O livro Teodora \& Cia. teve boa aceitação? Ele lhe ampliou os horizontes literários? 
Boos - O destino sempre trabalhou a meu favor. Certa ocasião, o editor Carlos Jorge Appel veio a Florianópolis e, em seguida, embarcou para Brusque, utilizando a antiga rodoviária que ficava na Avenida Hercílio Luz. Para passar o tempo durante a viagem, ele foi a uma banca de jornal, onde encontrou o livro Teodora \& Cia. Ele leu o livro durante a viagem, que naquela época durava quatro horas. Chegando $\mathrm{a}$ Brusque, ele se dirigiu à casa de sua prima, dizendo que havia apreciado bastante a leitura. Appel perguntou à prima se conhecia o autor do livro e ela informou: "-Sim, é claro. Ele mora nesta mesma rua, no outro lado!". Lá foi o Appel à minha casa, dando surgimento a uma grande amizade. Ele sempre me incitava: "-Ainda vou publicar um livro seu!". Ele queria algo sobre a guerra do contestado e naquela época eu saía muito com o Julio Dutra, major da polícia e que havia trabalhado como delegado. Dutra se apaixonara pela guerra do contestado e tinha vários livros sobre 0 assunto. Pór outro lado, Appel sempre surgia dizendo: “- O contestado está à sua espera". Diante disso tudo, eu recorri ao Dutra, que não demorou muito a surgir na minha casa com seis livros sobre o assunto. Eu li todo o material sobre a guerra do contestado e julguei que tudo aquilo daria um bom livro. A forma já estava mais ou menos pronta na minha cabeça, eu só necessitava dos fundamentos.

RCH - Após longos anos trabalhando como funcionário do $\mathrm{BB}$, você se aposentou e mergulhou na carreira literária. Como são esses novos tempos? Boos - Neste mês (Março/2009), eu receberei a visita de Carlos Jorge Appel, o representante da Editora Movimento. O objetivo é acertar a continuação do romance Quadrilátero, mais a publicação de um livro de contos. Eu estou interessado que Appel logo defina as condições para a publicação desses livros. $O$ texto que eu tenho em mente mistura fantasia, realismo mágico e tem como cenário a esquina da rua Bocaiúva, próximo à Chácara do Molenda, onde eu nasci. Eu já tenho alguns apontamentos sobre história e estou ansioso para iniciar a construção do texto. Trata-se de uma experiência nova para mim, pois o romance envolve muitos personagens, imagens eflashbacks. De vez em quando, eu recebo visitas inesperadas, como a de Leonardo Toulouse, professor da Universidade de Paris que caiu de pára-quedas na minha vida. Ele tem dupla cidadania - o pai é francês, mas ele nasceu no Brasil - e leciona Literatura Brasileira. Ao fazer uma pesquisa sobre a influência da colonização sobre a nossa literatura, Toulouse se viu forçado a discorrer sobre a cultura alemã. Ele soube de meu livro Quadrilátero e, 
casualmente, encontrou um exemplar à venda num dos sebos de Paris. É a mão poderosa do destino! A França é conhecida por seus inúmeros sebos e meu livro não foi traduzido para o francês. Eu não sei como o livro foi parar lá, mas eu suspeito que tenha sido da família de um rapaz de Santa Catarina, o qual teve que sair às pressas do Brasil, por ocasião da eclosão do golpe militar (1964). É possível que ele tenha falecido e a família teve que se desfazer da obra, visando desocupar espaço nas estantes. $O$ prof. Toulouse viu a obra e imediatamente a adquiriu. Quando ele veio ao Brasil para ministrar uma palestra na Universidade de Brasília, ele indagou se alguém conhecia o escritor Adolfo Boos. Uma dessas pessoas era justamente Regina, nora do Salim, que imediatamente informou que me conhecia muito bem. Na mesma hora ela telefona para o Salim, anota o meu endereço e repassa a informação para Toulouse. Ele telefonou para marcar uma entrevista e nós tivemos uma longa conversa, que durou das 9:00 às $24: 00 \mathrm{~h}$.

RCH - Como v. cria suas obras? Qual é a sua rotina de trabalho?

Boos - O escritor é um parasita, vive à custa dos outros, das experiências alheias! Nós temos o costume de olhar para as pessoas e ver personagens literários. São os vícios do ofício. Eu fui forjado a golpes de machado, não sigo nenhuma teoria literária e gosto muito de ler ficção. Eu sempre tive compulsão à leitura e, após a aposentadoria no BB, eu mergulhei no mundo da literatura. Eu não dirijo automóveis, raramente vou aos supermercados e me dedico integralmente à literatura. Eu acordo bem cedo, tomo o meu café da manhã e inicio a minha jornada de trabalho. O meu estúdio é um quarto desocupado de empregada, onde existe uma despensa que utilizo para colocar meus livros. A familia aceitou a minha decisão e, portanto, eu me isolo até às $10 \mathrm{~h}$ da noite: lendo, relendo e escrevendo. Eu tenho a minha maneira própria de trabalhar: durante algum tempo eu fico com uma idéia na cabeça, arquitetando um modo como contar a história, pois cada história exige um procedimento ou abordagem diferente. Quando eu me dirijo para o computador, eu despejo minhas idéias e não interrompo o processo até colocar um ponto final. Deixo o material em banho-maria, mais ou menos finalizado. Após algum tempo, eu retorno às idéias para "trabalhar o texto", coisa que aprendi saindo da boca do Salim - eu era um brutamontes e não sabia como finalizar adequadamente um texto. Atualmente, eu não faço outra coisa, senão escrever e reler meus livros preferidos; a disciplina adquirida como funcionário do $\mathrm{BB}$ tem sido muito útil. 
RCH-OGS produziu peças teatrais e esteve à frente do primeiro filme realizado em Santa Catarina, embora muitos pensem que o modernismo estivesse restrito às atividades literárias. Descreva suas impressões sobre essas atividades.

Boos - O movimento modernista influenciou não somente a literatura, mas as artes de modo geral. Inicialmente, o GS montou algumas peças teatrais para financiar a criação da revista $S u l$. Eu me lembro bem como ocorreu uma dessas encenações, episódio divertido envolvendo Ody Fraga e Armando Carreirão. Os dois atuavam como ator e no controle do ponto, respectivamente, numa peça de Jean Paul Sartre (1905-80), filósofo e escritor francês. O palco tinha dois aposentos, separados por um jogo de iluminação - uma peça ficava iluminada, enquanto a outra permanecia no escuro. Os controladores de luzes eram peças de baquelita que ficavam dentro da caixa de ponto; eles eram barulhentos e quem acionava o mecanismo era Carreirão. A encenação teatral foi marcada por grande improvisação e a equipe de apoio foi abandonando o trabalho à medida que cumpria a função-a vergonha era enorme! Ao final da peça, Ody ficava deitado numa chaise longue, enquanto as luzes iam se apagando e as cortinas se fechando. O controle da tarefa fícou ao encargo do Carreirão, mas ele já havia abandonado o local. Ody ficou esperando o fechamento das cortinas, mas nada aconteceu. Ele esperou longos minutos, mas ao final perdeu a paciência $\mathrm{e}$ informou à platéia: " $-\mathrm{A}$ peça acabou!". Todos se levantaram e foram embora. No dia seguinte, surgiam os comentários sobre o inusitado final: "-Sartre é foda!"

RCH - Qual é a sua opinião sobre o filme do Salim e Eglê?

Boos - O título do filme era $O$ preço da ilusão. Ele até que era bom, mas se perdeu na montagem. Ele foi enviado para São Paulo, onde foi montado de modo completamente errado e sem supervisão. Isso explica o fracasso do filme: eles pagaram o "preço da inexperiência". Infelizmente, nada de significativo foi produzido desde então, exceto documentários eventuais.

RCH-Qual é a sua avaliação sobre a revolução modemista conduzida pelo GS? Boos - Eu acho que o saldo é imensamente positivo, pois o GS está na cabeça de todas as pessoas que trabalham com literatura. Ele impulsionou Florianópolis para a modernidade, embora a geração seguinte não tenha feito nada de significativo, exceto nas artes plásticas. Eu publiquei Teodora \& Cia. quando eu já estava no Banco do Brasil. A decisão de encerrar as atividades do GS foi em conjunto e partiu do seguinte pressuposto: "quem tinha asas, que alçasse vôo próprio." 


\section{Grupo Sul e a Revolução Modernista em Santa Catarina}

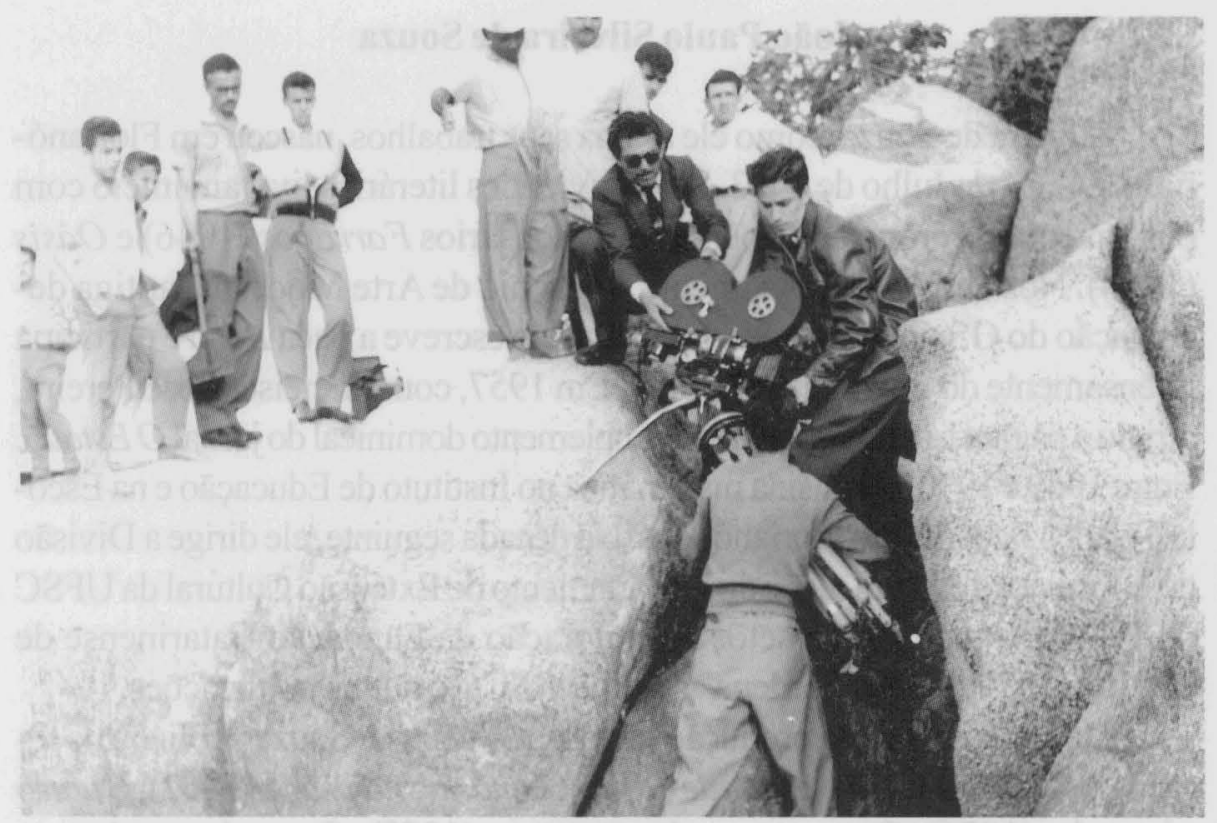

\section{Figura 7}

A equipe em ação durante as filmagens de "O preço da ilusão" (1957). A partir da esquerda: Murilo Pirajá Martins (o quarto), Salim Miguel (no centro e de paletó branco) e Armando Carreirão (óculos escuros).

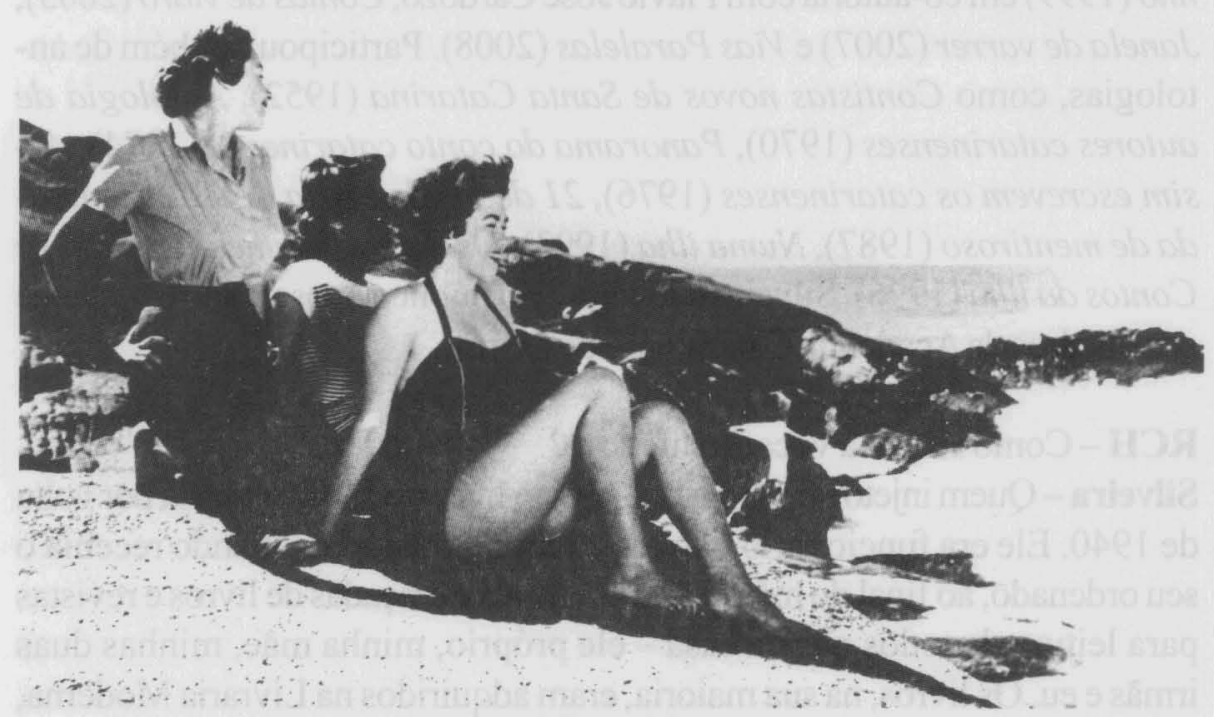

Figura 8

Mulheres figurantes de "O preço da ilusão" (1957). 


\section{João Paulo Silveira de Souza}

Silveira de Souza, como ele assina seus trabalhos, nasceu em Florianópolis/SC, 27 de Julho de 1933. Suas atividades literárias tiveram início com publicações de crônicas e poemas nos mensários Farrapos (1946) e Oásis (1948). Nos anos 1950, ele integra o Círculo de Arte Moderna, antiga designação do GS. Por essa mesma época, ele escreve a peça Beco e participa intensamente do grupo teatral TESC. Em 1957, com Francisco José Pereira, dirigiu a página Literatura e Artes do suplemento dominical do jomal $O$ Estado. Entre 1960 e 1970, ele ensina matemática no Instituto de Educação e na Escola Técnica Federal, em Florianópolis. Na década seguinte, ele dirige a Divisão de Informação e Divulgạ̧ão do Departamento de Extensão Cultural da UFSC (1971-76), atua junto aọ setor de editoração da Fundação Catarinense de Cultura (1979), onde coordena as Edições FCC e outras publicações.

Dono de uma vasta prođução literária, Silveira de Souza publicou os seguintes livros: O vigia e a cidade (1960), Uma voz na praça (1962), Quatro alamedas (1976), Os pequenos desencontros (1977), O cavalo em chamas (1981), Canário de assobio (1985), Um ônibus e quatro destinos (1994) em co-autoria com Francisco José Pereira e Holdemar Menezes, Rumor de folhas (1996), Relatos escolhidos (1998), Trololó para flauta e cavaquinho (1999) em co-autoria com Flávio José Cardozo, Contas de vidro (2003), Janela de varrer (2007) e Vias Paralelas (2008). Participou também de antologias, como Contistas novos de Santa Catarina (1952), Antologia de autores catarinenses (1970), Panorama do conto catarinense (1974), Assim escrevem os catarinenses (1976), 21 dedos de Prosa (1980), Cambada de mentiroso (1987), Numa ilha (1993), Os dez mandamentos (1996) e Contos da ilha (1996). Silveira é funcionário público aposentado e pertence aos quadros da Academia Catarinense de Letras.

RCH - Como surgiu a vocação literária?

Silveira-Quem injetou em mim o micróbio literário foi meu pai, lá por volta de 1940. Ele era funcionário público e leitor entusiasta. Quando recebia o seu ordenado, ao final do mês, costumava trazer braçadas de livros e revistas para leitura de todos nós da casa - ele próprio, minha mãe, minhas duas irmãs e eu. Os livros, na sua maioria, eram adquiridos na Livraria Moderna, situada na rua Felipe Schmidt, que pertencia ao Sr. Pedro Xavier; as revistas vinham provavelmente da Banca do Sr. Beck, na Praça XV de Novembro. 
Nessa idade eu já aprendera a ler com minha mãe. Ganhava não só livros de histórias para crianças, coleções da Editora Melhoramentos, mas também revistas em quadrinhos, o Almanaque do Tico-tico, coisas assim. Meu pai não tinha o hábito de escrever; era subdiretor de Contabilidade do Tesouro do Estado e os seus passatempos caseiros, além da leitura, eram a flauta e o charadismo. Quanto à flauta, em certa ocasião ele mandou importar da Alemanha, por intermédio de uma empresa de São Paulo, uma flauta transversa Boehm. Essa encomenda demorou dois ou três meses para chegar e eu ainda lembro do nervosismo, da ansiedade com que ele esperava o instrumento. Chegada por fim a flauta, de imediato ele passou a ministrar o meu primeiro aprendizado de prática e teoria musical. Aprendi a ler partituras, a interpretar na flauta algumas pequenas peças de música popular, valsas, chorinhos, foxtrots, aquilo que na época se chamava "tango brasileiro" e muitos exercícios de escalas. Mais tarde, no início dos anos 1950, cheguei a participar aqui em Florianópolis de uma Orquestra Juvenil, regida por Mário Loureiro, da qual, entre outros músicos, faziam parte pessoas então bastante próximas, como O.F. de Melo Filho, Hélio Teixeira da Rosa e Pedro Bosco. Numa apresentação que essa Orquestra fez no Teatro Álvaro de Carvalho, eu interpretei uma pequena peça de Villa-Lobos para coral e flauta, assim como um arranjo para flauta e orquestra da Processión, de Sarda. Do meu pai charadista, que colaborava com uma ou duas revistas de outros estados criando charadas e logogrifos (atividade que estava em alta naquela época), recordo de um grupo de amigos aficcionados que vinha uma vez por semana a nossa casa e ali ficava, às vezes até tarde da noite, na sala de visitas, bebendo vinho ou cerveja, a emitir em altas vozes palavras as mais esdrúxulas e a inventar situações extremamente enigmáticas. Veja: só isso, as leituras de livros e revistas, a música e aquele estranho mundo de palavras e enigmas extravagantes jogados ao acaso em altas vozes noite a dentro, já poderiam instilar na mente de um garoto uma forte tendência para o mistério e a ficção. Mas houve também as leituras em voz alta.

RCH - Música e literatura se misturavam no ambiente familiar... Descreva melhor esse consórcio.

Silveira-Lá pelos meus 11 ou 12 anos, a diversão maior lá em casa era ouvir rádio. Claro, vivíamos no Brasil a plena "Era do Rádio". E era através do aparelho de rádio que tínhamos em casa, uma caixa abaulada com a marca da holandesa Philco, que acompanhávamos o noticiário sobre a II Guerra Mundial, 
o noticiário político do país através do Repórter Esso, as marchinhas que seriam cantadas no próximo Carnaval, muitos programas humorísticos e musicais, principalmente os das rádios Tupy e Record, do Rio de Janeiro e São Paulo. Os cinemas não eram muito frequentados por nós nesse estágio de minha vida. Então, durante a semana, tínhamos o vagar suficiente para reuniões noturnas da família em volta da mesa da sala de estar, quando minhas irmãs faziam rodízio para leitura em voz alta de contos e romances. Foi desse modo, através do ouvido, que pela primeira vez conheci alguns contos de Machado de Assis, de Edgar Allan Poe, de Monteiro Lobato, de Conan Doyle, de Guy de Maupassant, de Eça de Queiroz, As mil e uma noites e outros autores. Reconheço, hoje, que aquelas sessões de leitura em voz alta, que geravam comentários e discussões diversos, foram de importância fundamental para a minha formação de leitor e escritor (mais leitor que escritor, certamente). Parece que hoje em dia as famílias já não dispõem de muito tempo para tais sessões. Mas acredito que os colégios, pelo menos alguns colégios, estejam cumprindo essa missão. Enfim, esses primeiros contatos que tive com a literatura descortinaram em minha mente um universo complexo de magia, sonho e realidade. Aquela diversidade de acontecimentos que os livros ofereciam, a multiplicidade de personagens e cenários, alguns tão próximos, tão familiares e outros tão distantes e exóticos; as diferenças tão marcantes de destinos humanos, que variavam numa escala de mendigos a príncipes e reis; as conjunções de alegrias e sofrimentos, misérias e faustos; tudo aquilo fazia com que eu me perdesse em especulações e questionamentos mentais. E não cabe dúvida que a vibração interior que eles despertavam passou a estimular o desejo ou a vontade de também escrever coisas assim, coisas que pudessem atingir a sensibilidade de um possivel leitor e, ao mesmo tempo, pudesse ser um instrumento muito particular de investigação e de compreensão de mim mesmo e do universo a minha volta.

RCH - Na meninice, quais eram suas leituras preferidas? O que mais lhe fascinava?

Silveira-Numa primeira fase, entre os meus 8 e 10 anos, a fase da "braçada de livros" trazidas mensalmente por meu pai, recordo de algumas publicações que me atingiram em cheio, ou seja, que me encantaram ou comoveram de modo especial. Entre elas posso mencionar: As Reinações de Narizinho e $O$ Garimpeiro do Rio das Garças, livros de Monteiro Lobato; Alice no País das Maravilhas, de Lewis Carrol (numa adaptação de Lobato), 
o Pinóquio, do italiano Carlo Collodi; um volume intitulado Histórias da Mata Virgem, que eram histórias de onças, macacos, raposas, jabutis e outros espécimes da fauna brasileira, do qual não tenho certeza quem era o autor, mas suponho ter sido Renato Sêneca Fleury e uma inesquecível adaptação, toda ilustrada, de contos de Hans Christian Andersen (teria sido trabalho de Lobato?), obra que reli diversas vezes, principalmente as maravilhosas histórias de um soldadinho de chumbo, de um patinho feio, de um isqueiro mágico (que termina numa ampla sala no interior do tronco de uma árvore, guardada por assombrosos cães com olhos de pires), de um rouxinol mecânico, da inexistente roupa nova de um rei, de uma garota que calçou um par de sapatinhos vermelhos enfeitiçados, que nunca paravam de dançar, até que a garota morreu de puro esgotamento físico e psicológico. Devo acrescentar ainda $A$ terra dos meninos pelados, um livro que achei estranho, diferente, mas que fascinava de certa maneira muito particular, de um autor, Graciliano Ramos, que mais tarde, no final dos anos 1950, passou a ser uma de minhas leituras mais impressivas. Numa segunda fase, a das leituras em voz alta, livros e autores de um nível literário mais denso, ou "adulto", passaram a ser objeto de leituras paralelas, agora individuais e silenciosas. Além de buscar outros títulos dos autores das leituras em voz alta, Machado de Assis, Monteiro Lobato, Edgar Poe, Maupassant, Arthur Conan Doyle, etc., também outros nomes despertaram a minha atenção, como Jules Verne ( $V i$ agem ao centro da Terra, 1864), H.G. Wells (A guerra dos mundos, 1898) e Robert Louis Stevenson ( $A$ ilha do tesouro e $O$ médico e o monstro, 1883 e 1886). A leitura que mais me sensibilizou nesse período foi $O$ morro dos ventos uivantes, (1847), de Emily Brontë. Foi nesse período que eu comecei a ler os primeiros poetas, aqueles que estavam em alguns livros guardados nas prateleiras de um armário envidraçado, na sala de entrada de minha casa, a biblioteca de meu pai: Olavo Bilac, Casemiro de Abreu, Raimundo Correia, Castro Alves, Cruz e Sousa, Álvares de Azevedo, Gonçalves Dias. Na verdade, as obras de poesia geralmente não eram lidas na íntegra, mas apenas os poemas mais conhecidos e citados na época (um que outro eu até sabia de cor), como por exemplo: Mal secreto e As pombas, de Raimundo Correia; Navio negreiro, de Castro Alves; Ora, direis, ouvir estrelas, do Bilac; Meus oito anos, de Casemiro de Abreu; Se eu morresse amanhã, de Álvares de Azevedo; Canção do exílio e I-Juca Pirama, de Gonçalves Dias; Caminho da glória, de Cruz e Sousa; e alguns outros mais. 
RCH -Muitos escritores relatam o fascínio juvenil pelas histórias em quadrinhos, especialmente de ficção científica. V. também foi seduzido por elas? Silveira - Tudo bem. A literatura era uma feiticeira envolvente. Mas devo confessar que os que mais me "fizeram a cabeça", entre os 12 e 14 anos, foram alguns álbuns de histórias em quadrinhos, especialmente o de Flash Gordon no Planeta Mongo, de Alex Raymond (1905-56). Esse álbum foi um deslumbre e ainda guardo um exemplar dele, numa edição mais recente. Pela primeira vez, na minha curta e limitada vidinha (isso no início dos anos 1940), eu me deparava com uma aventura humana desenvolvida fora do nosso planeta, em outra "bola girante no espaço", em Mongo, com foguetes espaciais, animais monstruosos, seres que eram um misto de homem e leão, de homem e peixe, de homem e pássaro, todos convivendo num mesmo espaço uma aventura fantástica, narrada num ritmo estonteante, em desenhos maravilhosos. E essa impressão não era só minha. Os garotos de minha rua que não podiam comprar o álbum, faziam fila para a sua leitura na sala de minha casa. Pois eu não o emprestava a ninguém. Não mesmo. Poderia emprestar qualquer um dos livros "comuns", mas quando se tratava do álbum de Flash Gordon eu era de um egocentrismo brutal.

RCH-Qual foi a maior contribuição do GS? Quem eram os intelectuais que mais se destacaram no movimento modemista?

Silveira - Parece-me que a professora Lina Leal Sabino sintetizou muito bem a importância do GS, ao dizer em seu livro Grupo Sul: O modernismo em Santa Catarina (1982, FCC Edições): "Desconhecemos notícias de outro movimento na literatura de Santa Catarina que tenha sido tão longo (dez anos), tão abrangente (teatro, cinema, artes plásticas, literatura) e que tenha produzido tantos frutos. Não só frutos dentro da época a que pertence cronologicamente, no caso a transformação estéticoliterária dos anos 40 e 50, mas também pelos nomes que, aí gerados, realizam-se vida em fora". Entre os frutos da época poderíamos citar a criação do Museu de Arte Moderna; a inovação das apresentações teatrais com a encenação de peças de grandes dramaturgos do século 20 como, por exemplo, George Bernard Shaw e Pirandelo. $O$ impulso dado às artes plásticas, com o apoio a exposições e o acolhimento nas páginas da revista Sul de trabalhos dos melhores artistas locais, abrindo assim o caminho para a criaçåo, mais tarde, do Grupo de Artistas Plásticos de Florianópolis (GAPF); 
a experiência com o filme $O$ preço da ilusão, primeiro longa metragem realizado em Florianópolis; na literatura, a "descoberta" de Guido Wilmar Sassi, que embora a rigor não tivesse pertencido ao GS, teve o seu primeiro livro, Piá, lançado pela Edições Sul. E se pensarmos nos nomes que, gerados pelo GS, "realizam-se vida em fora". Aí estão os livros de Salim Miguel e Adolfo Boos Júnior, entre os melhores da moderna literatura de Santa Catarina.

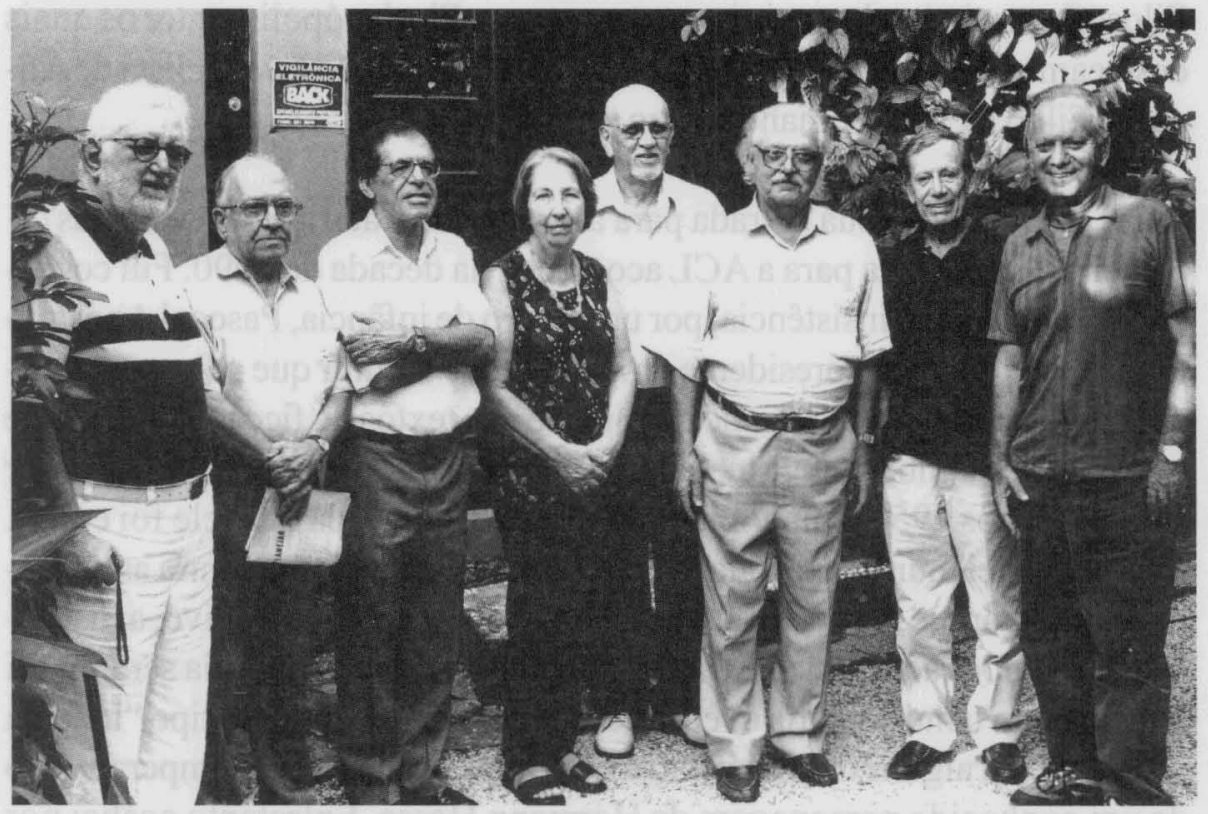

Figura 9

Alguns membros do Grupo Sul no lançamento do documentário "Modernos do Sul", dirigido pela jornalista Kátia Klock (2004). A partir da esquerda: Archibaldo Cabral Neves, João Paulo Silveira de Souza, Tercio da Gama, Eglê Malheiros, Adolfo Boos Jr., Salim Miguel, Walmor Cardoso da Silva e Miro Morais.

RCH - Fora da Academia Catarinense de Letras e do Grupo Sul, existia alguma movimentação intelectual?

Silveira - Quase ao final das atividades do GS surgiu o grupo Litoral, que era liderado pelos irmãos Pascoal e Nicolau Apóstolo Pítsica. Eles começaram com uma página literária semanal no jornal $O$ Estado, depois editaram a revista Litoral, que deu nome ao grupo. Mas o movimento teve curta duração. 
Nesse contexto surgiram jovens de talento, como C. Ronald, Iaponan Soares, Rodrigo de Haro, (que mais tarde também participou do Grupo de Artistas Plásticos de Florianópolis, GAPF) e Pedro Garcia. Eles todos de certo modo usufruíram do clima inovador implantado pelo GS. Outro marco importante para o desenvolvimento intelectual catarinense foi a fundação da Faculdade Catarinense de Filosofia (1954), uma das instituições que deram origem a Universidade Federal de Santa Catarina (1960). A Faculdade de Filosofia atraiu intelectuais importantes para Florianópolis, entre os quais destacamos Agostinho da Silva, Eudoro de Souza, João Evangelista de Andrade Filho e Paulo Fernando Lago.

RCH - Como foi a sua entrada para a Academia Catarinense de Letras? Silveira - A entrada para a ACL aconteceu na década de 1990. Fui convidado, com alguma insistência, por um amigo de infância, Pascoal Apóstolo Pítsica, que era então presidente da ACL. Devo admitir que o Pascoal sempre havia demonstrado grande admiração aos textos de ficção literária que eu escrevia e também deve ter contribuido para esse convite o fato de eu ter sido, nos anos 1950, colaborador da revista Litoral, da qual ele foi editor. Mas eu relutei muito em aceitar o convite, não porque fosse contra as academias, mas porque me considero avesso, sabe-se lá porque motivo, a discussð̃es e reuniões acadêmicas. O meu trabalho de criação literária sempre foi uma luta um tanto solitária e reconheço ter um temperamento tipo "lobo da estepe", com alguns traços bastante próximos (creio eu) do temperamento de um conhecido personagem de Hermann Hesse. Entretanto acabei por aceitar e me submeter à votação para a Cadeira 33, tendo sido eleito. Por que aceitei? Vaidade? Não creio. Antes, me parece haver predominado como válida, na época, a seguinte racionalização: a ACL não interfere na criação literária individual de seus membros e é uma instituição que soma para os esforços de valorização dos autores de Santa Catarina.

RCH - Como os intelectuais da época viam o GS? Qual era a origem de tantas animosidades em relação a ele?

Silveira - Não participei diretamente dos anos iniciais do GS, ou seja, do período entre 1948 e 1951, quando as reações contra as atividades do grupo parecem ter sido as mais visíveis e acirradas. Em 1948 eu tinha 15 anos de idade, ainda era aluno do Ginásio (hoje Colégio) Catarinense e podia ver 
que boa parte dos professores não admitiam as liberdades formais existentes nos poemas e textos publicados pelos componentes do GS, o que pode parecer estranho, pois essas liberdades já haviam sido assumidas em 1922 pelo Movimento Modernista no Brasil. Em casa, meu pai, que era um homem de mente aberta, despida de preconceitos, também estranhamente relutava em aceitar aqueles novos parâmetros de construção literária. Então, pode-se admitir que havia, em Florianópolis, um desconhecimento quase total a respeito das consequências da Semana de Arte Moderna, ocorrida em São Paulo (1922), que se somava a uma espécie de inércia intelectual, um apego às formas consagradas do passado. Esse apego era instilado principalmente pelas obras de escritores e poetas, brasileiros e portugueses, como Alexandre Herculano, Camilo Castelo Branco, Camões, Eça de Queiroz, Machado de Assis, Olavo Bilac, Coelho Neto, Monteiro Lobato e outros. Muitos não se davam conta de que vivíamos outro momento, já bastante distanciado daquelas influências literárias. A propósito, o próprio Lobato, um homem extraordináriamente lúcido em tantos aspectos, foi uma das reações mais notáveis contra a Semana de 22 .

RCH - As críticas ao GS eram pertinentes ou sinalizavam o conservadorismo da época?

Silveira-Em Floripa, as reações mais qualificadas (para os leitores em geral) vieram de intelectuais da Academia Catarinense de Letras, como Altino Flores e Othon D'Eça. Altino foi o mais radical, pois além de acreditar na literatura e na arte como algo de inspiração a bem dizer "divina", repudiava não só o estilo "chulo", os palavrões, enfim a vulgarização da linguagem daqueles modernistas, como também fazia restrições ideológicas: para ele, aquele movimento, dito cultural, parecia inspirado pelas idéias políticas do comunismo internacional. Quando, em 1951, comecei a fazer parte do GS, os aspectos formais de "nova" literatura já estavam suficientemente assimilados pela maioria dos leitores, mas ainda perduravam as "pechas" de que éramos todos um bando de comunistas. O que verifiquei não serem verdadeiras. Havia comunistas assumidos, sim, mas havia também adeptos das mais diversas ideologias políticas, sociais e religiosas. Predominava, é certo, uma visão geral mais à esquerda, o que era sem dúvida uma característica dos mais importantes intelectuais do século em todo o mundo. No GS se evitava qualquer proselitismo ideológico, além do que pudesse transparecer em manifestações puramente individuais. 
RCH-V. foi professor de matemática e muitos imaginam que tal disciplina é incompatível com a produção artística e literária. O que v. tem a dizer sobre isso? Silveira - É uma pergunta que sempre me assusta nas entrevistas que tenho feito. Na verdade, acredito que o fato de ter sido, durante cerca de 10 anos, um professor de matemática para estudantes de nível médio, de modo algum me habilita a falar dessa estrutura tão complexa do conhecimento humano. Então, o que posso relatar é alguma coisa da minha experiência pessoal numa dimimuta fração dessa monumental estrutura. Paradoxalmente, o interesse pela matemática começou lá pelo final dos anos 1950 , quando resolvi "tirar a limpo" o fato de eu ter sido até ali um péssimo aluno de matemática nos colégios. Cheguei mesmo a ser reprovado em matemática na terceira série ginasial. Daí eu me perguntava: será isso um problema meu, uma espécie de deficiência mental, ou os professores não estavam acertando o modo de ensinar essa disciplina, de modo que eu e grande número de outros alunos deixassem de sentir tanta dificuldade de entendêla? Era uma pergunta razoável, até mesmo com um leve matiz científico. Devo também acrescentar que, por essa época, eu costumava ler obras de caráter filosófico de Bertrand Russel (1872-1970), que foi um dos nomes mais respeitáveis da nova lógica matemática e isso me deixava mais frustrado ainda em relação a minha indesculpável ignorância do assunto. Pois bem, a partir daí comecei a estudar matemática, a princípio por conta própria, em livros didáticos e mais tarde ingressando no curso de Matemática da UFSC. Foi uma experiência pessoalmente bastante válida, que me abriu novos horizontes em relação a diversos assuntos, inclusive a criação literária. Ainda hoje, mesmo afastado do magistério e de cursos de matemática, ainda reservo algum tempo para a leitura de livros e textos de divulgação, principalmente de lógica simbólica.

RCH - Entretanto, muitos ainda persistem na idéia de que matemática e as artes são universos mutuamente excludentes...

Silveira - A idéia de que a matemática é incompatível com a literatura e a arte não deixa de ser um equívoco grosseiro. Ao contrário, hoje eu não tenho dúvidas de que se existe um tipo de conhecimento que possa ser compatível com tudo o mais, esse é o conhecimento lógico-matemático. Ele está visceralmente ligado ao nosso dia-a-dia, em qualquer cogitação comercial ou que exija qualquer tipo de estratégia. Está na raíz da nossa linguagem articulada, 
de toda linguagem articulada. A questão é que em geral associamos erroneamente a matemática, quase exclusivamente, com cálculos numéricos, quando na verdade ela se refere à nossa capacidade de estabelecer relações, seja entre objetos "reais", seja entre idéias abstratas. E podemos encontrar escritores que usaram explicitamente de conceitos lógico-matemáticos ou da física na construção de algumas de suas histórias, como Lewis Carroll, Edgar Allan Poe, Thomas Mann, Jorge Luis Borges, Ítalo Calvino e Umberto Eco, para citar só alguns. Se você ler, por exemplo, o livro Discusión, de Borges, vai encontrar uma resenha sobre o livro Matemática e imaginação, de Edward Kasner e James Newman (traduzido no Brasil pela Editora Zahar) e um ensaio intitulado Avatares de la tortuga, a propósito de um dos mais conhecidos paradoxos de Zenão. É claro que essas criações literárias não são criações matemáticas, embora tenham se valido delas. Literatura e matemática são coisas diferentes, mas não são incompatíveis entre si, assim como não vejo nenhuma incompatibilidade entre literatura e geografia, literatura e história, literatura e filosofia, literatura e o diabo a quatro. A literatura envolve todo o universo humano e, por consequência, todo o universo do conhecimento humano.

RCH - A literatura deve ter uma função social?

Silveira - Eu perguntaria, a prostituição deve ter uma função social? A corrupção tem alguma coisa a ver com o social? Chego a acreditar que tudo o que um homem faz, tem a sua cota de social. Pois o comportamento de um homem (ou mulher), quem quer que seja ele (ou ela), pode afetar pessoas que lhes estão próximas. A literatura, em geral, preocupa-se, ainda que de maneira fictícia, com o ser humano. E se aceitarmos que ela é uma forma de comunicação, então a sua natureza é transitiva, isto é, busca alcançar um público receptor, de preferência o maior possível. Quando o editor distribui um livro para um determinado público, a mensagem do livro torna-se social. Então, inevitávelmente, a literatura tem o seu lado social. Pode-se discutir se esse lado social é ou não o mais importante, mas a presença dele é indiscutível, mesmo que seu autor não tenha nenhuma preocupação neste sentido.

RCH - Quais são os novos projetos?

Silveira - Até agora eu realizei textos de pequena dimensão, contos, crônicas e alguns poemas. Tudo bem, nada contra isso, acho até que foi uma boa experiência, no sentido de uma gratificação interior muito pessoal. 


\section{HUMANAS}

Mas agora a idéia de algo maior (ou, pelo menos, mais extenso) começa a se infiltrar em minha mente. Imagens ainda um tanto caóticas, situações, rostos, personagens, ambientes, tudo isso querendo ganhar corpo, exigindo a minha atenção. Começo a tomar notas, a buscar um caminho no interior do caos. Por certo está pintando uma novela ou um romance. Mas ainda é cedo para saber o que será. Ainda estou à espera daquilo que chamam de "salto quântico", aquela faísca que um elétron solta quando pula de uma órbita mais alta para outra mais baixa e que hoje é entendida como símbolo da criatividade, a faísca capaz de estabelecer uma ordem no caos.

RCH-O que é mais importante numa obra? A história ou estilo?

Silveira-Em geral as obras literárias de ficção tem o que se poderia chamar de uma história e a gente sempre pode identificar nelas um estilo. $O$ estilo talvez seja aquilo que nos faz gostar mais de um autor que de outro. Não é só o modo de construir sentenças, mas o modo de conduzir ou escolher personagens, de refletir sobre o que é essa coisa tão estranha que é o ser humano a viver num universo estranho. Mas devo confessar que não me prendo muito a esses mecanismos teóricos. No meu modo de ver, o mais importante numa obra é o seu feitiço, aquela coisa mágica que te envolve e te leva até o final da leitura com a sensação de que você conheceu um outro mundo, ou uma outra dimensão até então desconhecida de teu próprio mundo.

RCH - Atualmente, nós dispomos de recursos tecnológicos que facilitam a produção de textos, mas não surgiram talentos como Machado de Assis ou Cruz e Sousa. Qual é a sua opinião sobre esse assunto?

Silveira - Eu penso que a tecnologia é muito importante, tão importante quanto a ciência propriamente dita. Isso pode ser visto de modo mais imediato na medicina: os progressos tecnológicos são impressionantes (PETScan e os exames tomográficos). Falamos faz pouco alguma coisa de matemática. Pois já foi dito que a evolução da matemática do século 18 até a presente data foi extraordinariamente maior que a sua evolução da antiguidade até o século 18, isto graças às invenções e aperfeiçoamentos a partir deste século de máquinas de calcular, culminando em nossos dias com o computador. Na Idade Média, por exemplo, um astrônomo despendia um tempo enorme, que poderia ser de vários meses, para resolver uma complexa equação matemática. Com o desenvolvimento das máquinas de calcular, o trabalho de resolver os "carroções numéricos" foi enormemente reduzido, 
abrindo um espaço muito maior para a pura criação e incrementando portanto os avanços da ciência. Atualmente, os computadores permitem simulações do clima de um planeta distante e testes de hipóteses sobre a possibilidade ou não de vida em outras regiões do Cosmo; esses cálculos envolvem algoritmos complexos e dificilmente seriam resolvidos sem o uso de computadores. Mas é quase impossível para mim dizer se tais recursos tecnológicos, que deram um impulso tão grande à ciência, possam ter algum efeito, positivo ou negativo, em relação à criação literária e artística. Acredito que não. Além do mais, os talentos excepcionais dificilmente nascem em pencas. Se no século 19 tivemos Machado de Assis e Cruz e Sousa, no século 20 acho que podem ser considerados como grandes criadores um Guimarães Rosa, um João Cabral de Melo Neto, um Carlos Drummond de Andrade.

\section{Flávio José Cardozo}

Nasceu em Lauro Müller, SC, em 2 de novembro de 1938. É jornalista, escritor e manteve por vários anos uma coluna de crônicas no jornal Diário Catarinense. É autor das primeiras traduções das obras de Jorge Luis Borges (1899-1986), conhecido escritor argentino. Cardozo foi premiado no Concurso Universitário de Contos (Porto Alegre, 1965), no Concurso Nacional de Contos (Florianópolis, 1967), no I Concurso Nacional de Contos do Paraná (Curitiba, 1968) e no Concurso Remington de Literatura (Rio de Janeiro, 1977). Seu primeiro livro de contos foi Singradura (1970); oito anos depois veio Zélica e outros (1978). Os dois livros têm como cenário a Ilha de Santa Catarina, época em que a cidade não tinha as feições turísticas atuais. Outros livros são Água do pote (1982), Sobre sete viventes (1985), Longinquas baleias (1986), Beco da lamparina (1987), Sofá na rua (1988), Tiroteio depois do filme, (1989), Senhora do meu desterro (1991), Trololó para flauta e cavaquinho, em parceria com Silveira de Souza (1999), Uns papéis que voam (2003), Guatá (2005), um conjunto de contos em andamento de romance que tardiamente retoma o cenário da vila da infância, e Duas violas arteiras, em parceria com Sérgio da Costa Ramos (2008). Cardozo é funcionário público aposentado e pertence aos quadros da Academia Catarinense de Letras.

RCH - Como foi a sua infância? 
Cardozo - Nasci na região carbonifera de Santa Catarina, no município de Lauro Müller, bem no pé da Serra do Rio do Rastro. Passei a infância, até os onze anos, no distrito do Guatá, uma vila de trabalhadores das minas. $\mathrm{O}$ meu último livro tem o nome dessa vila (Guatá, 2008). A infância me marcou bastante, mas não influenciou de imediato a minha literatura. Ainda garoto, me desliguei desse ambiente, passando por um período de transição num seminário, isso depois que pela nossa região andaram uns padres em busca de vocações sacerdotais. Eram frades da Ordem dos Servos de Maria (Servitas), que tinham o seminário em Turvo, cidade próxima a Araranguá, no Sul do estado. Uns vinte moleques atenderam à chamada e lá foram para o seminário - na verdade, todos nós queríamos ver um mundo novo, escapar daquela pobreza, e o seminário acenava com boas perspectivas de educação $e$ futuro. Para desencanto de minha mãe, que já me via padre, fiquei lá bem pouco tempo, cerca de um ano e meio. Não tinha nenhuma vocação. Agora, que foi uma experiência muito importante para mim isso foi. Na nossa casa de família pobre nós tínhamos apenas uma Bíblia resumida, almanaques, $\mathrm{e}$ só. Na escolinha, meia prateleira de um armário com uns dez livros. No seminário tive contato com uma coisa chamada biblioteca.

RCH-Quais eram as leituras preferidas do jovem seminarista?

Cardozo - Os livros eram pré-selecionados pelos padres, claro que eles não iam deixar que lêssemos qualquer coisa. Lá estava o sempre bem lembrado Tesouro da Juventude, a coleção Terramarear de aventuras, o livro Cora$c ̧ \tilde{a} o$, de Edmondo de Amicis... Tive a sorte de ter um grande professor de Português, que nos mandava fazer bastante redação e era muito severo na correção. Chamava-se frei Romeu, o melhor professor que já tive. Ele era filho de uma família abastada do Rio de Janeiro, mas havia deixado tudo para seguir a vida austera de religioso e a pobreza voluntária com os demais padres. A formação oferecida no seminário era muito boa, mas aquela maneira de viver era um sacrificio para além das minhas forças, aquela disciplina rigorosa, aquelas orações tão compridas. Eu não era bem um exemplo de fé e devoção e estava ocupando o espaço de alguém com verdadeira vocação religiosa. Vou sempre reconhecer que os padres eram uns abnegados e que o período vivido no seminário, mesmo tão curto, me influenciou bastante, sobretudo em relação ao meu gosto pela leitura e às minhas primeiras tentativas com a escrita. 
RCH-Existia algum tipo de castigo físico no seminário?

Cardozo - Não, mas havia uma punição que nos causava algum desconforto, embora a gente entendesse muito bem que ela visava à nossa disciplina, os nossos bons modos. No refeitório, quando alguém derrubava um talher no chão, já sabia o que devia fazer: tinha de ir lá diante da mesa dos padres e se ajoelhar. Ficava de joelhos por uns bons minutos, ouvindo o barulho do pessoal comendo, e só voltava ao seu lugar quando o padre reitor autorizava com um toque de campainha. Não sei se era uma estratégia dos padres para ensinar os alunos, mas certo dia um deles derrubou um talher e não teve dúvida, ele foi ajoelhar-se e lá ficou até ser perdoado. A cena me impressionou, mas até hoje desconfio que aquilo era uma jogada combinada para melhor instruir a turma.

RCH - Embora tenha nascido no pé da serra, boa parte da sua obra explora essencialmente o cenário litorâneo. Quais as razões para tal?

Cardozo - Vim a conhecer o mar somente por volta dos doze anos de idade, quando ainda estava no seminário. No verão, os padres organizavam excursões à praia do Arroio Silva e do Morro dos Conventos, em Araranguá, para entretenimento da gurizada. Conseguiam um caminhão de algum colono e lá iam todos na maior alegria do mundo. A praia ficava a uns trinta quilômetros, a estrada era de cascalho, saíamos bem cedo. A primeira vez, então, que vi o mar foi uma coisa fantástica, quase tive um treco de tanto deslumbramento: eu era do pé da serra, mal imaginava como podia ser o tal Oceano Atlântico, e a imagem daquela vastidão me provocou uma emoção de fato muito forte. Foi uma impressão que nunca mais se apagou. Uma crônica de Afonso Romano de Sant'Anna também descreve o primeiro dia em que ele se deparou com o mar, algo bem semelhante ao que ocorreu comigo. Quem nasce próximo ao mar não faz idéia dessa experiência - eu brinco com minha mulher, que nasceu em Florianópolis, dizendo que sinto muita pena dela por não ter entre suas grandes lembranças essa da descoberta do mar já com mais idade. Uns anos depois, aquela revelação física acontecida no Arroio Silva teve um complemento, refinou-se com a leitura de Homens e algas (1957), de Othon d'Eça. Esse livro veio dar uma nova dimensão ao meu sentimento pelo mar, pois agora eram reveladas vidas humanas vivendo junto a ele e dele, não era apenas aquele cenário grandioso, era também o espaço de muitas histórias, de muita poesia. O livro de Gama d'Eça foi fundamental para a minha opção pelo ambiente praiano como um filão literário. 


\section{UMANAS}

Admiro muito Othon d'Eça também por sua atuação em nosso meio cultural, por sua fama de bom conversador e por ter tido um espírito sempre aberto para os jovens. Olhava com grande simpatia os jovens modernistas, embora sem nenhuma vinculação com o GS.

RCH - Como foi o seu relacionamento com o GS?

Cardozo-Meu relacionamento com o GS foi apenas o de um curioso, um tímido espectador. Eu tinha mais ou menos vinte anos quando vim morar em Florianópolis, em 1957, ou seja, o GS já estava em sua fase final, pois se deu por encerrado no ano seguinte. Era ainda um guri, fui estudar no Colégio Dias Velho, fazia minhas redações nas aulas da professora Carolina e do Nereu Corrêa e gostava muito de ler. Acompanhava o movimento literário, as atividades do GS, lia a revista $\mathrm{Sul}$ na Biblioteca Pública. Frequentei a livraria Anita Garibaldi, do Salim, gostava de ir ver as novidades, mas só ver, porque dinheiro que era bom só no bolso dos outros, não no meu. Se bem me lembro, o único livro que comprei lá foi exatamente Homens e algas. Me relacionei um pouco mais foi com o pessoal da minha idade. Na minha sala do Curso Clássico estudava o Paschoal Apóstolo que, junto com o irmão gêmeo Nicolau, foi um dos fundadores do grupo Litoral. Como eu era bonzinho em Português, colaborei com a revista Litoral como revisor, a convite do Paschoal, atividade que no futuro acabou sendo especialmente muito útil, pois pôde ser contada como um ano de serviço no meu tempo de aposentadoria. Bem, minha participação em grupo, portanto, foi com o Litoral - e na condição de revisor da revista, nada com alguma criação minha. Do GS sempre foi uma distância respeitosa, espiando de longe. $O$ mais próximo que eu estive foi da Eglê Malheiros, que era nossa professora de História, no Dias Velho, e do Aníbal Nunes Pires, que dava aquela matéria medonha chamada Matemática. O pessoal todo do GS eu via como que nas alturas, pois já haviam publicado livros e eu nem chegava ainda a sonhar com isso.

RCH - O que v. tem a dizer acerca do desaparecimento do GS?

Cardozo-O grupo era ambicioso, atuava em várias frentes e deu mesmo uma boa mexida no ambiente. Está aí a História registrando isso. Havia uma enorme ansiedade criadora dentro do grupo, o que talvez tenha acabado por provocar uma exaustão falo da atividade do grupo como grupo, não do potencial de cada um. O GS foi um movimento muito solidário, cheio de entusiasmo, 
e esse entusiasmo de vários de seus elementos continuou (ainda continua), como foi o caso de Guido Wilmar Sassi, e até hoje o de Salim Miguel, Eglê Malheiros, Adolfo Boos Jr., Silveira de Souza.

RCH-Alguns escritores relatam que são leitores compulsivos. V. pertence a este grupo? Leituras e releituras facilitam o processo literário?

Cardozo-No processo de formação, como a maioria dos que se imaginam com alguma tendência para escrever, fui bastante ansioso para produzir algo. Chegava a doer aquilo de ver o tempo passando e nada acontecer. Via os outros produzirem e eu tão pouquinho, só as redações de colégio, umas experiências em jornal, a participação em concursos. Com o tempo, fui administrando o meu ritmo, me conformando com minha lentidão natural. $\mathrm{O}$ primeiro livro, Singradura, saiu quando já estava com 32 anos, e o segundo, Zélica e outros, oito anos depois, ambos ambientados na Ilha de Santa Catarina. A idéia de escrever sobre a região da minha infância só se tornou concreta em 2005 (Guatá). Escrevi um bom tempo para jornal e alguns livros com seleção de crônicas apareceram. No que diz respeito às leituras, elas são desordenadas, não obedecem a método algum. Já fiz alguns esforços para ser mais disciplinado, mas sem resultado. De qualquer maneira, acho que o que li me deu bastante proveito. Hoje, não leio tantas novidades como lia antes, mas em compensação releio bem mais os autores que me marcaram. Esse processo de releitura é uma necessidade, é um reencontro em que, mais maduro, reverencio a criação dos maiores.

RCH - Atualmente, dispomos de vários recursos tecnológicos que facilitam a produção literária. Qual é o seu comentário sobre esses avanços da modernidade?

Cardozo - A tecnologia facilita o trabalho digamos braçal, mas não necessariamente a criação artística. Pode até facilitar, mas não se conte com isso. Os recursos tecnológicos agilizam a obtenção de informações e a elaboração material de um texto, mas o modo de escrever de outros tempos combina mais com os requisitos necessários a uma boa produção literária, que sempre pede concentração e ponderação. A facilidade atual talvez torne a mente mais dispersiva. Uma de minhas primeiras leituras foi o Tesouro da Juventude, decisivo para despertar minha vocação literária como foi decisivo, eu sei, para despertar a vocação de muita gente para outras atividades, basta lembrar o famoso Livro dos porquês... Essa influência, 


\section{HüMANAs}

naquele preciso momento, foi mais importante que todo o acervo do Google. Tenho medo de que, por ser tão facilitária e estar tão disponível a um simples toque de dedo, a massa de dados no computador iniba a imaginação, a fantasia, instrumentos da literatura. As idéias e o conteúdo dos livros sobreviverão às inovações tecnológicas, eles podem ganhar diferentes formatos e aspectos mas não deixarão de ser livros.

RCH-Em que contexto os recursos tecnológicos podem ser úteis? Cardozo - A tecnologia serve bem mais aos negócios, à educação, à divulgação científica do que à criação artística, tão carregada de emoção e subjetividade. Como um pintor pode extrair dessa tecnologia uma obra mais sua, mais com sua alma? E o escritor, na solidão da experiência? A tecnologia é utilíssima - e como! - para o trabalho físico da escrita. A lei do menor esforço também funciona para o escritor, é claro. Já se escreveu em placas de barro, em papiros, em pergaminhos, escreve-se em papel, já se escreveu com pena de pato, canetas-tinteiro, máquinas, escreve-se com computador, sei lá com que ainda se vai escrever. Mas a criação mesmo é lá dentro, com o pensamento. $O$ instrumental varia, se sofistica, mudam os hábitos. Comecei a trabalhar com computador no Diário Catarinense, pioneiro em Santa Catarina na adoção desse recurso de trabalho. No começo, uma certa estranheza; mas hoje como me imaginar sem computador para escrever? Escrever no sentido de botar as palavras no papel, não no de fazer literatura, bem entendido.

RCH-Ainda há espaço para temas universais na literatura? Inquietações existenciais ou conflitos religiosos ainda despertam interesses nos leitores?

Cardozo - A literatura lida essencialmente com o ser humano, com tudo o que é do ser humano, as inquietações, os sonhos, o lado bom, o lado mau, os conflitos. Os temas são recorrentes, eternos. Por serem do homem, todos os temas que incessantemente abastecem a literatura são universais. A literatura é a arte da palavra, para exercitar essa arte todos os temas são válidos. Por mais que um tema tenha sido explorado, sempre haverá oportunidade para 0 surgimento de uma boa obra literária com seus toques de originalidade, vai valer aí a maneira como o velho tema tenha sido aproveitado. Como com as jogadas no xadrez, são quase infinitas as situações de enredo numa ficção, a descoberta de sugestões num poema. Mas as grandes questões da aventura humana estarão sempre se repetindo na elaboração literária e sempre interessando à curiosidade do leitor sensível. 
RCH - O que leva alguém a produzir uma obra literária? A compulsão é irresistível?

Cardozo - Até hoje não sei por que escrevo. As possibilidades são várias. Uns imaginam que se escreve para fugir da rotina e ir para uma realidade inventada mais interessante ou prazerosa, outros que escrever é uma forma de poder, é dar uma de semi-deus manipulando destinos, outros que é para melhorar o mundo, para divertir as pessoas, por pura vaidade etc. etc. A melhor resposta talvez seja que é por isso tudo ao mesmo tempo. Seja como for, não chega a ser uma questão que me angustia. Quanto à intensidade, sempre achei que eu me sentiria muito mais feliz se tivesse uma boa compulsão irresistível para escrever, em vez dessa minha maneira devagar. Não precisaria ser como dizia William Faulkner (1897-1962), para quem nada importa ao escritor além de escrever seu livro, nem honra, nem decência, nem felicidade, nada, e que se um escritor precisar roubar a própria mãe para escrever não deve hesitar um só momento. Não precisaria ser assim, mas seria ótimo se eu tivesse um pouco mais de obsessão, ficasse mais tempo batucando as teclas, atravessasse dias e noites escrevendo, mas isso é para alguns eleitos.

RCH - E as pressões do mercado editorial? O que é um best seller?

Cardozo-Num conceito mais tradicional, a literatura busca o prazer estético a partir da palavra, mantém seu caráter criativo em torno das mil e uma sugestões da existência humana. $O$ escritor não assume a pretensão de salvar o mundo, quer apenas dar algum testemunho sobre o que o cerca ou simplesmente inventar algo que dê prazer ao leitor. Olhando assim, a literatura é um jogo inocente e de uma necessidade relative; o mundo não sucumbiria sem ela, muito embora sempre terá influência nas mentes e nos corações humanos. Agora, como produto de consumo, o livro é capaz de cada vez movimentar mais dinheiro. Há uma "indústria literária" para um mercado definido, movida por regras de produção bem eficientes. Livros e livros são publicados em linhas de montagem - e isso, de um modo geral, tem muito pouco a ver com a literatura propriamente dita. Prevalecem as conhecidas fórmulas de sucesso. Não vejo nenhum motivo para censurar quem quer que seja por ler esses livros, é questão de gosto e de formação, e viva a liberdade. Ler bem é um estágio alto, é consequência de um aprendizado e de um desenvolvimento contínuo. Para os que apreciam de verdade a boa leitura $o$ que importa é que ela sempre tenha seu espaço e aconteça sempre. 


\section{HÜMANAS}

RCH - Algumas obras apontam problemas sociais e contribuíram para o aperfeiçoamento das instituições. Não seria uma outra modalidade de literatura?

Cardozo - A literatura pode e deve percorrer todos os caminhos da realidade humana. Ela dá testemunho, enriquece a visão de mundo, emociona, causa maravilhamento. Não mata a fome física de ninguém, mas pode ser uma extraordinária companheira de viagem. A vida é mais vida com um bom livro. E muito de denúncia social, de inconformismo tem passado pelos livros. Quantas vezes o instrumento para isso é o humor, a sátira? Estou pensando agora, por exemplo, naquela Uma proposta modesta de Jonathan Swift(1667-1745), que propunha aos irlandeses que as crianças de rua fossem abatidas para alimentar os abonados e que mexeu com a sensibilidade de todo mundo. Mas, embora com a literatura seja possível abalar consciências, a função dela não é a de estabelecer linhas de conduta, esse papel cabe mais na boca dos pregadores. O escritoré um observador da vida, um contador de invenções a partir do que vê e sente. O que ele conta pode ser bonito ou feio, bom ou mau. É a vida. Ele está no rolo da existência e fica bem melhor sendo o que é, parceiro de todos os homens.

RCH - Fale um pouco sobre o processo literário.

Cardozo - Cada um tem seu jeito de trabalhar. Como já disse, sou do tipo vagaroso, vagaroso até demais. Se me perguntam, digo que não chego a me considerar alguém no pleno oficio de escritor, me sinto um praticamente quase envergonhado. Não sei se é excesso de autocrítica ou uma manha inconsciente para não me cobrarem além da conta. De qualquer maneira, indeciso ou não, a verdade é que na hora de escrever a gente cria coragem e vai ousando, às vezes com uns ares meio megalomaníacos. O escritor pode ser bem consciente de sua limitação na vida real, mas diante do papel ele busca nada menos que o melhor, nada menos que a perfeição. Às vezes até acha que chegou lá. Se acaba fazendo algo pelo menos digno de respeito já fica de bom tamanho...

RCH - O mundo atual vive uma verdadeira revolução digital e o cidadão comum encontra uma ampla variedade de entretenimento. Diante disso, qual é o futuro do livro?

Cardozo - Vejo o livro assim bem definido: sua parte física e seu conteúdo. A parte física é o que é, um suporte. Não me assusta nada que amanhã o livro me caia nas mãos ou me entre pelos olhos com uma forma diferente dessa com a qual estou habituado. As placas de argila, os pergaminhos e tudo mais cederam lugar ao papel e os leitores foram se adaptando às várias mudanças. 
O homem busca sempre a novidade mais prática. A realidade digital deu tantos benefícios ao relacionamento humano que o que ela consolidar em relação ao livro há de ser proveitoso. É verdade que estamos tão bem acostumados com o livro do jeito que é que a mudança para outras formas soa até meio agressiva. Mas ele, por mais que mudarem suas aparências, será sempre e cada vez mais um dos primeiríssimos bens da Humanidade.

\section{Lauro Junkes}

Ele nasceu em Florianópolis/SC, 9 de Março de 1942. Bacharel em Filosofia, Licenciado em Letras e Bacharel em Direito pela Universidade Federal de Santa Catarina; o Mestrado também foi concluído também na UFSC (1976) e o doutorado, em Lingüística e Letras/Teoria da Literatura, pela Pontifícia Universidade Católica do Rio Grande do Sul (1993). Foi professor da UFSC, onde ingressou em 21 de Março/1973. Seus interesses se voltam para a produção literária em Santa Catarina e o resgate da memória de antigos escritores do nosso estado; criou a disciplina "Literatura Catarinense", a qual serviu de inspiração ou ponto de partida para várias teses de pós-graduação. É integrante do Conselho Estadual de Cultura de Santa Catarina (desde 2002) e tem atuado como presidente da Academia Catarinense de Letras em diferentes mandatos (2003-2004, 20042006 e 2006-2008). Junkes é autor de uma biografia sobre um dos principais modernistas de Santa Catarina (Aníbal Nunes Pires e o grupo Sul, 1982), além de duas dezenas de outros livros. Após trinta e três anos de atuação junto ao Departamento de Língua e Literatura Vernácula, ele se aposentou como Professor Titular.

RCH-Descreva o desenvolvimento de sua carreira literária?

Junkes - Atualmente, eu sou professor universitário aposentado, mas ainda tenho algumas orientações de teses pendentes. Não sou escritor "criativo", pois dediquei-me sempre mais à função de leitor que escritor, e meus interesses se voltam para a história e crítica literária. A partir de 1976, eu decidi estudar os escritores catarinenses, pois tinha terminado o mestrado e resolvi fazer algo diferente. Não havia quase nada sobre a literatura produzida em Santa Catarina, pelo que decidi estudar a nossa produção literária. Nesse sentido, eu inaugurei uma página no Jornal de Santa Catarina, de Blumenau, em cujo suplemento dominical eu criei a coluna "Catarinenses fazem literatura". 
Ali devo ter publicado mais ou menos 40 trabalhos, pois o suplemento foi extinto em 1979. Mantive também uma página semanal no jornal $A$ Gazeta, onde publiquei cerca de 450 edições, na coluna "Livros \& Cultura", até o fechamento do jornal. Com as mudanças de rumos nos jornais e a valorização das seções de esportes e sinopses de telenovelas, eu fui perdendo meu "solo firme". Esses suplementos literário-culturais eram comuns até os anos 1980, mas terminaram com o crescimento das páginas dedicadas aos esportes e televisão; gradativamente, a literatura perdeu espaço nos jornais. A minha produção jornalística diminuiu, mas esporadicamente eu ainda contribuía com críticas publicadas em jornais como $O$ Estado, Florianópolis e $A$ Notícia, de Joinville. Após concluir o doutoramento, comecei a assumir orientações de alunos de pós-graduação (mestrado e doutorado), de modo que o meu tempo dedicado à leitura e análise de livros diminuiu. Senti isso como uma grande perda, porque o envolvimento com o suplemento literário impunha responsabilidade e exigia uma produção sistemática. Quando tais exigências desaparecem, a pessoa geralmente se acomoda e acaba seguindo outros rumos na carreira.

RCH-Quando v. passou a se interessar pelo modernismo catarinense?

Junkes - Eu tomei conhecimento da existência do GS a partir da convivência e estudo das obras de seus integrantes, quando entrei em contato com alguns escritores modernistas de Santa Catarina, principalmente Salim Miguel, Guido Wilmar Sassi e Silveira de Souza. Foi a partir desse contato que decidi examinar melhor o GS e os escritores catarinenses. Isso ocorreu por volta de 1979-80. Em seguida, eu publiquei um livro sobre o GS e outro sobre poesia catarinense, todos bem acolhidos pela crítica. Atualmente, eu me concentro na crítica literária e tenho interesse em resgatar a produção de antigos escritores catarinenses.

RCH-Abusca pelos antigos escritores catarinenses revelou a alguma surpresa? Junkes - Eu tive a surpresa de descobrir muita coisa boa, produzida por escritores de mais ou menos 100 anos atrás. Textos que não foram reeditados, mas de grande qualidade literária. Muitas dessas obras são praticamente desconhecidas dos leitores atuais, como as poesias completas de Luis Delfino, dois volumes com cerca de 1500 páginas; também reeditei os contos de Virgilio Várzea, importante escritor do final do século 19. 
Reeditei ainda a obra de completa do poeta Cruz e Sousa, o inédito Oscar Rosas e Ensaios Oratórios de Arcipreste Paiva, o maior orador sacro cuja obra havia cerca de 140 anos que fora reeditada. Eu ainda reeditei o primeiro livro literário catarinense - Assembléia das aves, de Marcelino A. Dutra (1847), Praias da minha terra \& outros poemas, de Juvêncio de A. Figueredo e resgatei de jornais a obra de Santos Lostada - Minutos de mar, estando no prelo a Obra completa de Delminda Silveira. Esse tipo de trabalho ultrapassa a função de um editor, pois envolve a sistematização, adaptação ortográfica e uma profunda revisão geral dos textos, pois eles foram escritos há mais de 100 anos atrás. Muito desse material foi publicado em jornais, material bastante delicado que necessita um manuseio cuidadoso, para evitar danos. Esse tipo de trabalho consumiu muita energia, mas me deu muita satisfação. É função da Academia Catarinense de Letras a preservação da língua, mantida em sua pureza, e a valorização dos escritores do passado, tornando a apresentar suas obras aos leitores.

RCH - Esses escritores estavam perdidos no tempo, mas eles tinham apenas relevância histórica ou suas obras tinham méritos intrínsecos?

Junkes -Eu li as obras desses escritores e percebi que eles têm valor, o que ultrapassa a simples relevância histórica. Muitas dessas obras são bem estruturadas e têm méritos intrínsecos. Elas estavam esquecidas ou eram inacessíveis aos leitores atuais e, portanto, eu pensei em dar uma nova chance a esses talentos do passado. Por exemplo, dentre as obras de Arcipreste Paiva, sobrevivia apenas um volume, trancado à chave na Biblioteca Pública. Para ter acesso a ela eu tive que obter uma autorização especial da diretora. O Luis Delfino foi eminente poeta do século $19 \mathrm{e}$ teve grande destaque até $o$ início do século 20, mas ele teve vários percalços: embora médico, rico e de condições para editar seus livros, nunca se interessou em publicar um livro. Grande profusão de suas poesias apareceu apenas nos jornais. O jornal é transitório e o material facilmente se perde no tempo. Tendo falecido em 1910, somente em 1926, o filho começou a editar seus poemas. Luis Delfino foi um autor romântico, influenciado pelo parnasianismo. Mas, a partir de 1920, nós tivemos o movimento modernista, o qual tinha por lema: "nós sabemos o que não queremos, ainda não sabemos o que queremos", ou seja, era ferrenho inimigo do parnasianismo, movimento literário quase oficial no Brasil na passagem do século 19 para o 20 e Olavo Bilac, o expoente do parnasianismo, 


\section{HUMANAS}

era muito achegado ao poder político e tinha pleno domínio sobre a opinião pública. Os modernistas não aceitavam o parnasianismo e os livros de Luis Delfino, publicados nessa época tiveram chance de bom recebimento e repercussão.

RCH - O que a ACL tem feito atualmente para preservar a memória desses escritores?

Junkes - Além de constantes recuperações das suas obras em novas edições em livros, nossa intenção é colocar os textos de autores antigos na Internet, todas que são de domínio público. O mesmo está sendo feito em relação às revistas Terra e Sul, pelo NUPILL da UFSC, permitindo que pesquisadores e demais interessados tenham acesso livre a todas as edições. A revista Sul ainda não caiu no domínio público, mas nós estamos negociando com os antigos editores para que ela seja colocada à disposição de todos os leitores.

RCH - Descreva o cenário em que surgiu o modernismo catarinense.

Junkes - A Semana de Arte Moderna ocorreu em 1922, introduzindo a estética modernista nas letras e artes do Brasil. A partir de 1900 já existia uma certa tendência pré-modernista. Em Santa Catarina, porém o parnasianismo perdurou de 1880 até 1948 , ocasião em que houve a deflagração do movimento modernismo no estado. Por que tão tarde? Porque a Academia Catarinense de Letras foi criada por um grupo de escritores estreitamente afinados com os moldes do parnasiano e a influência se fixou fortemente e perdurou por muito tempo, embora o modernismo já fosse uma tendência predominante no cenário brasileiro. $O$ conceito de academia, aliás, lembra qualquer coisa de natureza muito formalista ou uma instituição refratária às renovações das idéias. A resistência ao modernismo impôs a Santa Catarina meio século de atraso! O GS surgiu como resistência ao marasmo que predominava em nosso estado e o nome inicial "Círculo de Arte Moderna" se justificava: seus componentes queriam arte e, mais especificamente, arte moderna, pois somente a arte moderna seria capaz de vencer a barreira imposta pelo parnasianismo. O círculo é um grupo de pessoas em que todos têm voz igual, é democrático, sem impor lideranças absorventes. O espírito do GS era (e tinha de ser) de afronta e, portanto, os modernistas enfrentaram muitas dificuldades no início de suas atividades.

RCH - Por volta dos anos 1940-50, quais eram os intelectuais da ACL que mais se destacavam? 
Junkes - AAcademia Catarinense de Letras foi fundada por José Boiteux e um grupo de jornalistas/escritores em 1920, mas produziu poucas obras relevantes nas primeiras décadas, como, aliás, toda a primeira metade do século 20 teve produção literária reduzida em Santa Catarina. Os únicos intelectuais que tiveram destaque foram aqueles de espírito mais aberto, que não se submetiam ao parnasianismo oficial, ou que resistiram às conveniências momentâneas. Dentre aqueles que se destacaram na produção literária, cito Othon Gama D'Eça, escritor de espírito aberto, Maura de Senna Pereira, a maior poetisa de Santa Catarina, e Tito Carvalho, jornalista que adotou o estilo regionalista e retratou o modo de vida e a rudeza instintiva de seus personagens. Esses intelectuais eram dotados de espíritos independentes e viviam à margem da academia; daqueles que se submeteram ao parnasianismo oficial, nenhum prosperou.

RCH - Como o Círculo de Arte Moderna se transformou em Grupo Sul? Esqueceram as "artes modernas"?

Junkes - Os modernistas tinham adotado o nome "Círculo de Arte Moderna", mas ficaram conhecidos como o "Grupo Sul”, sobretudo após a criação da revista $S u l$. Esta começou a ser divulgada por todas as regiões do Brasil, da América Latina e até a África de língua portuguesa. Ela recebia colaborações de várias regiões. Como a imprensa de São Paulo e Rio de Janeiro se referia frequentemente àqueles "rapazes do Sul", àquele dinâmico grupo da revista $S u l$, aos poucos se popularizou o nome "Grupo Sul", que acabou predominando, a ponto de hoje quase ninguém se referir ao original "Círculo de Arte Moderna". É importante lembrarmos que, antes da década de 1950, praticamente não se ouvia falar em arte moderna, em Santa Catarina.

RCH - O modernismo promoveu alguma mudança no cenário cultural da época?

Junkes - A maior contribuição foi a renovação da literatura e das artes plásticas em Santa Catarina. Havia uma boa produção artística e literária no final do século 19, com autores como Cruz e Sousa, Luis Delfino e Virgilio Várzea. Com a passagem do século 20 esses escritores foram desaparecendo e não surgiu ninguém relevante no cenário. A qualidade caiu e diminuiu a produção artística. Em 1896, foi fundada a Academia Brasileira de Letras e outras academias em diferentes estados. Em Santa Catarina, a primeira vez que foi levantada a idéia de se criar uma instituição dessa natureza ocorreu em 1912, 


\section{HüMANAS}

por iniciativa de Othon Gama D'Eça, mas a idéia não prosperou. Em 1917, ele retornou com a mesma idéia e um amigo dele, Altino Flores, fez a seguinte pergunta: “-A criação de uma academia é interessante, mas quem irá compor seus quadros? Nós não temos escritores!". Houve uma intensa discussão (1910-20) e alguns escritores iniciantes e jornalistas resolveram fundar a revista Terra, episódio de grande significado histórico, pois ela foi o início de uma revitalização, embora de tendência tradicionalista. A revista durou pouco (1920-21) e era semanal, no início, passando depois a mensal; do ponto de vista artístico, inclinava toda para o parnasianismo. Aliás, o parnasianismo tentou preservar sua raízes no Brasil inteiro nos inícios do novo século, projetando-se como o que havia de mais importante, a verdadeira arte! Dentro desse contexto, foi criada a Academia Catarinense de Letras, por iniciativa de José Boiteux. Ela surgiu a partir da criação da revista Terra, que revelou existirem alguns escritores em Santa Catarina. Altino Flores era um homem muito realista e nada escapava ao seu olhar crítico, pois ele sempre achava algum defeito por melhor que fosse uma obra. Essa característica tem um lado bom, outro ruim: desestimula os novos escritores, mas também permite $o$ aperfeiçoamento dos textos. Aos poucos foram surgindo mais escritores $\mathrm{e}$ muitos entraram para a academia, inclusive o próprio Altino Flores.

RCH-O que os modernistas tinham em mente? O GS era um movimento literário ou os interesses eram mais amplos?

Junkes - Era composto por jovens irrequietos. Eles tinham em mente a superação do tradicionalismo e do marasmo literário-cultural que vicejavam na época, refrigerando o o ambiente provinciano com as idéias modernistas. O movimento se projetou mais na produção literária, porém desde o início manteve ampla abrangência estética. Logo no início, o GS encenou uma peça teatral de Jean-Paul Sartre (1946), autor praticamente desconhecido naquela época e cuja encenação constituiu a inauguração do teatro moderno entre nós. O teatro ainda persistia como uma diversão imprescindível no país, pois vinha do tempo em a sociedade apenas se encontrava nos bailes, nas missas em que as pessoas ficavam ouvindo os padres falando por horas e no teatro, antes de haver rádio, cinema e televisão. Entre nós, as peças teatrais daquela época seguiam o esquema tradicional, pouco inovador, predominando as peças românticas. O Grupo promoveu a primeira exposição de pintura moderna em Florianópolis e criou Museu de Arte Moderna, ainda hoje atuante, 
no CIC. Em seguida, os membros do Círculo de Arte Moderna conseguiram uma página dominical no jornal O Estado (1949) e surgiu a idéia de publicar um "romance", uma obra escrita a cada semana por uma pessoa diferente. Alegando que se tratava de uma tradução de um romance de um grande escritor inglês, a obra foi conquistando bastante sucesso. Mas, a página não perdurou muito, devido à polêmica que se estabeleceu entre os "novos" (modernistas) e os "velhos" (parnasianos), polêmica que se desenvolveu através das páginas de $O E s t a d o$, até chegando ao nível das agressões.

RCH - Eles enfrentaram dificuldades com os antigos intelectuais?

Junkes - O Aníbal Nunes Pires facilitou muito a aceitação do GS, mas Altino Flores dificultou sua aceitação. O jornal $O$ Estado havia cedido o espaço para o grupo, mas, a certa altura, Altino reclamou, alegando que o GS era composto por jovens baderneiros que não sabiam o que queriam da vida. A manifestação gerou enorme polêmica no jornal e Altino acabou invocando a sua autoridade para proibir a publicação da página dominical dos modernistas. Altino Flores foi um dos primeiros jornalistas de Santa Catarina, foi dono de jornal por muitos anos e havia atuado como secretário do governo; o jornal $O$ Estado não mais lhe pertencia, mas ele atuava como importante assessor e, num determinado momento, fez uso de sua autoridade, o que fechou as portas do jornal aos modernistas do GS.

RCH - V. estudou o surgimento do modernismo em Santa Catarina e dedicou um de seus livro ao Aníbal. Descreva os personagens que estiveram à frente desse movimento.

Junkes - Uma das lideranças mais importantes dentro do GS foi Aníbal Nunes Pires. Ele era oriundo de uma família tradicional, a qual chegou a ter um governador de Estado. Os jovens que compunham o GS tiveram que enfrentar um ambiente cultural hostil, eram irrequietos e afrontavam os intelectuais antigos. Por outro lado, Aníbal já era um poeta conhecido, havia se formado em duas faculdades e era professor em colégios importantes de Florianópolis. Com apenas 32 anos, já era uma autoridade respeitável. Apesar de anteriormente parnasiano, tinha espírito aberto e logo enxergou os méritos naqueles jovens. Simpatizou com eles e logo começou a marcar encontros. A partir desse momento, o escritor Aníbal se renovou e nunca mais publicou algo no estilo parnasiano. Como professor, valorizava as iniciativas de seus alunos, conversava abertamente e era bastante estimado; 
quando ele percebia o interesse de alguém pela literatura, estimulava e orientava a pessoa a produzir algo. Ele próprio publicou pouco, mas lia, relia e estimulava os novos escritores. A sua presença no GS dava um certo equilíbrio, o que facilitava muito o sucesso e a aceitação do movimento modernista.

RCH-Os antigos integrantes do GS reconhecem a importância de Aníbal, mas parece que ele próprio se deixara contaminar pelo modernismo...

Junkes-Aníbal influenciou e foi influenciado pelos jovens do GS. Ele deixou de lado toda a sua formação e passou a assumir os novos ideais estéticos, mesmo com problemas diante da sociedade tradicionalista. Aqueles jovens eram irrequietos, Salim Miguel era abertamente de esquerda e Eglê era filiada ao Partido Comunista, de modo que o envolvimento com o GS lhe trouxe muitos problemas, mesmo nos seus contratos de trabalho. Lembremos que Florianópolis era uma cidade pequena e conservadora e a ideologia comunista não era nada bem vista. A influência de Aníbal foi decisiva para a sobrevivência do grupo, pois sem ele o GS provavelmente teria experimentado maiores dificuldades para os rumos daqueles novos talentos prosperarem. A sociedade catarinense era extremamente conservadora e não aceitava nenhum tipo de radicalismo. Se Aníbal representava a moderação mais ponderada, a liderança pujante e intrépida dos jovens vinha de Salim Miguel. Sempre leitor incansável, assimilou as idéias modernistas e se empenhou para que, finalmente, o modernismo penetrasse no teatro, na música, nas artes plásticas, no cinema e, sobretudo, na literatura em Santa Catarina.

RCH-Qual é o legado cultural deixado pelo GS?

Junkes-É dificil sintetizar toda a influência do GS, mas podemos dizer que, dentro do cenário catarinense, ele representou uma explosão. Sob o impulso de Salim Miguel e a ponderação de Aníbal Nunes Pires, interrompeu-se a mesmice $e$ as artes sofreram um sopro renovador. As atividades do grupo abriram as portas para o teatro, música, cinema, artes plásticas e literatura. A abertura permitiu novos rumos para a cultura catarinense. Nas artes plásticas, 0 GS promoveu a criação do primeiro Museu de Arte Moderna de caráter oficial no Brasil e fez com que nomes importantes despontassem. O movimento modernista lançou outros nomes, os quais ganharam projeção nacional. No teatro, nós não tivemos muitos avanços, talvez porque essa área nunca foi dominante em nosso estado. Ody Fraga e Silva deixava todo mundo entusiasmado, 
mas na metade do andamento do GS ele saiu de Florianópolis, passou a atuar na área de cinema e se transformou no rei da pornochanchada e dos filmes de sexo explícito. Teria condições para dar uma boa contribuição para o desenvolvimento do teatro em nosso estado, mas acaba trilhando outros rumos na vida. $O$ cinema também não produzir obras em quantidade, mas é importante ressaltar o longa metragem $O$ preço da ilusão, cujo roteiro foi de responsabilidade de Salim Miguel e Eglê Malheiros. A produção mais relevante do Grupo Sul se concentrou na literatura, tendo projetado, sobretudo, quatro escritores do mais alto nível: Salim Miguel, Guido Wilmar Sassi,Adolfo Boos Jr. e Silveira de Souza. O saldo geral foi muito positivo. Os jovens modernistas imprimiram novos rumos a toda criatividade artística em Santa Catarina. Qualquer estudioso ou analista que examine a evolução artísticocultural do Estado chegará à mesma conclusão: a cultura catarinense, no século 20 se divide entre os tempos anteriores e os posteriores ao GS. Não tivesse ele existido, dificil seria imaginar como estaríamos hoje. 